\title{
Assessment of variety, clustering and adequacy of eating patterns : Dutch national food consumption survey
}

Citation for published version (APA):

Hulshof, K. F. A. M. (1993). Assessment of variety, clustering and adequacy of eating patterns : Dutch national food consumption survey. [Doctoral Thesis, Maastricht University]. Rijksuniversiteit Limburg. https://doi.org/10.26481/dis.19930513kh

Document status and date:

Published: 01/01/1993

DOI:

10.26481/dis.19930513kh

Document Version:

Publisher's PDF, also known as Version of record

Please check the document version of this publication:

- A submitted manuscript is the version of the article upon submission and before peer-review. There can be important differences between the submitted version and the official published version of record.

People interested in the research are advised to contact the author for the final version of the publication, or visit the DOI to the publisher's website.

- The final author version and the galley proof are versions of the publication after peer review.

- The final published version features the final layout of the paper including the volume, issue and page numbers.

Link to publication

\footnotetext{
General rights rights.

- You may freely distribute the URL identifying the publication in the public portal. please follow below link for the End User Agreement:

www.umlib.nl/taverne-license

Take down policy

If you believe that this document breaches copyright please contact us at:

repository@maastrichtuniversity.nl

providing details and we will investigate your claim.
}

Copyright and moral rights for the publications made accessible in the public portal are retained by the authors and/or other copyright owners and it is a condition of accessing publications that users recognise and abide by the legal requirements associated with these

- Users may download and print one copy of any publication from the public portal for the purpose of private study or research.

- You may not further distribute the material or use it for any profit-making activity or commercial gain

If the publication is distributed under the terms of Article $25 \mathrm{fa}$ of the Dutch Copyright Act, indicated by the "Taverne" license above, 


\section{ASSESSMENT OF VARIETY, CLUSTERING AND ADEQUACY OF EATING PATTERNS}

\section{DUTCH NATIONAL FOOD CONSUMPTION SURVEY}

\section{PROEFSCHRIFT}

ter verkrijging van de graad van doctor aan de Rijksuniversiteit Limburg te Maastricht, op gezag van de Rector Magnificus, Prof. Mr. M.J. Cohen, volgens het besluit van het College van Dekanen, in het openbaar te verdedigen op donderdag, 13 mei 1993 om 14.00 uur

door

Karolina Francisca Antonia Maria Hulshof 
Promotores: $\quad$ Prof. dr. ir. R. J.J. Hermus

Prof. dr. F. ten Hoor

Co-promotor: $\quad$ Dr. ir. M.R.H. Löwik

Beoordelingscommissie: Prof. dr. G.J. Kok (voorzitter)

Prof. dr. M.J. Drop

Prof. dr. ir. F.J. Kok (Landbouwuniversiteit Wageningen)

Prof. dr. ir. W.H.M. Saris

Prof. dr. W.A. van Staveren (Landbouwuniversiteit Wageningen)

CIP-DATA KONINKLIJKE BIBLIOTHEEK, DEN HAAG

Hulshof, Karolina Francisca Antonia Maria

Assessment of variety, clustering and adequacy of eating

patterns: Dutch national food consumption survey /

Karolina Francisca Antonia Maria Hulshof. -[s.l.:s.n.]. - Ill.

Thesis Maastricht. - With ref. - With summary in Dutch.

ISBN 90-9005977-6

Subject headings: diet / food consumption.

cover: H.F.F. Albers

Studies of this thesis were carried out at the TNO-Toxicology and Nutrition Institute and were financially supported by the Dutch ministries of Welfare, Public Health and Cultural Affairs and Agriculture, Nature Management and Fisheries and TNO Nutrition and Food Research.

Financial support by the Netherlands Heart Foundation and the Foundation Studiefonds $\mathrm{AGB}$ for the publication of this thesis is gratefully acknowledged. 
Ter nagedachtenis aan mijn vader Aan mijn moeder 


\section{Voorwoord}

Het onderzoek dat in dit proefschrift wordt beschreven kwam tot stand dankzij de inspanning en medewerking van velen. Allen die aan dit proefschrift hebben bijgedragen ben ik hiervoor zeer dankbaar.

Een bijzonder woord van dank ben ik verschuldigd aan de volgende personen:

Mijn promotores, prof. dr. ir. R.J.J. Hermus en prof. dr. F. ten Hoor. Beste Ruud en Foppe, hartelijk dank voor de prettige en stimulerende begeleiding gedurende de afgelopen jaren. De ontspannen sfeer tijdens de voortgangsbesprekingen, de kritische opmerkingen en de waardevolle suggesties gaven mij de moed om door te gaan.

Mijn co-promotor, dr.ir. M.R.H. Löwik. Beste Michiel, ik ben je zeer erkentelijk voor je vele originele ideeën en voor je grondige begeleiding bij het onderzoek. Zonder jouw enthousiaste inzet en hulp zou ik nooit zover zijn gekomen. Je leerde me niet alleen de puntjes op de ö te zetten!

Dr. Th. Ockhuizen. Beste Theo, als afdelingshoofd kwam jij op het idee 'iemand uit eigen stal' voor te dragen voor de uitvoering van een promotieonderzoek op basis van de eerste voedselconsumptiepeiling. Ik dank je voor het vertrouwen, voor het scheppen van de mogelijkheden nodig voor de realisatie en voor je morele steun.

Prof. dr. ir. F.J. Kok. Beste Frans, halverwege mijn promotie-onderzoek werd jij hooggeleerd en overhandigde je het co-promotorstokje aan Michiel. Dank voor je begeleiding en voor je belangstelling ook na je vertrek bij TNO.

Prof. dr. M. Wedel en Ing. C. Kistemaker. Beste Michel en Cor, jullie vervulden een cruciale rol bij de statistische analyses van het onderzoek. Hartelijk dank voor alle adviezen en hulp en voor het geduld bij het geven van de toelichtingen. Cor, zonder jouw vooruitziende blik bij de ontwikkeling van programmatuur, je enorme inventiviteit en je hulpvaardigheid bij het snel aanpassen van programma's had ik hel omvangrijke databestand niet kunnen hanteren.

Prof. Dr. W.A. van Staveren. Beste Wija, in het begin van de jaren ' 80 waren we beiden al betrokken bij besprekingen over surveillance in Nederland. Wie had toen kunnen denken dat de gegevens van de eerste voedselconsumptiepeiling de basis voor mijn promotie-onderzoek zouden vormen. Bedankt voor al je steun, adviezen en aanmoediging.

De (ex)collega's van de afdeling voeding van TNO. Hen ben ik veel dank verschuldigd voor de steun bij mijn eerste stappen op het gebied van wetenschappelijk onderzoek, voor de prettige werksfeer en voor alle hulp die mij is geboden. E.J.M. Aarnink, A.M.M.A.M. van Aken, M. Bouman en P.M. van der Es. Evelien, Arthur, Marco en Pita, jullie hulp bij de statistische verwerking was zeer welkom. 
Dr. A.M.J. van Erp-Baart. Marie-Agnes, jou dank ik voor de professionele wijze waarop je sinds medio 1989 de leiding aan de groep diëtetiek geeft. Het was fijn om gebruik te kunnen maken van de kennis aanwezig in deze groep. H.A.M. Brants, A. A.M. Colen, P. Schneijder en S. Westenbrink. Henny, Ann, Petra en Susanne, jullie kregen een ander 'opperhoofd'. Gelukkig kon ik blijven genieten van jullie collegialiteit. Mijn dank voor de jarenlange samenwerking, voor jullie hulp, steun en belangstelling. Merlijn Luten, als stagiaire diëtetiek wist jij waardevolle gegevens te verzamelen over de prijzen van voedingsmiddelen. Je enthousiaste bijdrage is erg gewaardeerd. C.W.G.M. van de Vaart, J.H. Pot, J.M. Leezer en N.A. Polter. Tineke, Annemieke, Hanny en Nora, jullie dank ik voor de bijdrage aan de verzorging van de manuscripten en de bijbehorende correspondentie, voor het leren van nieuwe foefjes op de computer en voor het verzorgen van de inwendige mens. Martin J. van de Vaart, jou ben ik erkentelijk voor het verzorgen van de figuren.

Dirk G. van der Heij. Mijn hartelijke dank voor de redactionele commentaren op de manuscripten en voor de correctie van het engels. Ook je adviezen en hulp inzakc de vormgeving van dit proefschrift heb ik erg gewaardeerd.

Hugu F.F. Albers. Het ontwerp en de verzorging van de omslag van dit boekje was bij jou in goede handen.

De 5898 dcclnemers aan de voedselconsumptiepeiling. Zij noteerden twee dagen lang clk hapje en elke slok. Zonder deze medewerking waren de huidige resultaten niet mogelijk geweest.

Het marktonderzoeksbureau AGB, verantwoordelijk voor de gegevensverzameling van de voedselconsumptiepeiling. Ik ben met name Ir. Alfred M. Dijs, Anne Louise Klijn-van Bijnen, Coen R. R. J. Snoeren en Piet J. van Turennout zeer crkentelijk voor hun aandeel in de organisatie en uitvoering van het veldwerk. De inzet van 54 free-lance diëtisten droeg bij aan het tot stand komen van een kwalitief hoogwaardige dataset; dank voor jullie enthousiaste medewerking. De vakbekwame supervisie van Marita Engelen-Donders en Sandra A.J.M. Verschuren en de deskundige adviezen van Lidwien J.M. van der Heijden zijn erg op prijs gesteld.

Het ministerie van Welzijn, Volksgezondheid en Cultuur en het ministerie van Landbouw, Natuurbeheer en Visserij. Zonder de financiële steun van deze ministeries was er geen voedselconsumptiepeiling geweest en was dit proefschrift dus ook niet geschreven. Mijn dank gaat dan ook uit naar beide ministeries, met name naar de contactpersonen met wie ik gedurende de afgelopen vier jaar constructieve bespekingen heb gehad over de voortgang.

Mijn familie en vrienden. Dank voor de belangstelling die jullie voor mijn promotie-onderzoek hebben getoond.

Mijn ouders ben ik dankbaar voor de mogelijkheid en vooral voor de motivatie die zij me gaven om te studeren. Moeder, uw belangstelling voor mijn werk was steeds een welkome stimulans. Jammer dat vader dit niet mee mocht maken. Aan U beiden draag ik dit proefschrift op. 


\section{Contents}

Abbrevations 1

1. Introduction 3

2. Nutritional surveillance in industrialized countries 9

Encyclopedia of Food Science. Food Technology and Nutrition (in press)

3. The Dutch National Food Consumption Survey: design, 21 methods and first results

Food Policy 1991;16:257-260.

4. Comparison of dietary intake data with guidelines:

some potential pitfalls (Dutch Nutrition Surveillance System)

J Am Coll Nutr (in press)

5. Diet and other life-style factors in different socio- economic groups

(Dutch Nutrition Surveillance System)

Eur J Clin Nutr 1991;45:441-450.

6. Clustering of dietary variables and other lifestyle factors

(Dutch Nutrition Surveillance System)

J Epidemiol Comm Health 1992;46:417-424.

7. Is food variety conducive to a more adequate diet?

Submitted for publication

8. General discussion and conclusions

Summary

Samenvatting

Curriculum vitae 


\section{Abbrevations}

\begin{tabular}{|c|c|}
\hline BMDP & biomedical computer programs \\
\hline BMI & body mass index \\
\hline DNFCS & Dutch National Food Consumption Survey \\
\hline DRDA & Dutch recommended dietary allowances \\
\hline EN\% & percentage of total energy intake \\
\hline EUROSTAT & $\begin{array}{l}\text { statistical office of the Commission of the European } \\
\text { Communities }\end{array}$ \\
\hline FAO & Food and Agriculture Organization of the United Nations \\
\hline FBS & food balance sheets \\
\hline GENSTAT & general statistic program \\
\hline HFHA & high fat/high alcohol \\
\hline HFLA & high fat/low alcohol \\
\hline ICS & $\begin{array}{l}\text { interlinked computer storage and processing system for } \\
\text { food and agricultural commodity data }\end{array}$ \\
\hline MD & mono- and disaccharides \\
\hline MFLA & medium fat/low alcohol \\
\hline MUFA & monounsaturated fatty acids \\
\hline NEVO & $\begin{array}{l}\text { Nederlands Voedingsstoffenbestand (Dutch food } \\
\text { composition table) }\end{array}$ \\
\hline NLG & Dutch guilders \\
\hline OECD & Organization for Economic Cooperation and Development \\
\hline $\mathrm{P} / \mathrm{S}$ ratio & $\begin{array}{l}\text { grams polyunsaturated fatty acids divided by grams } \\
\text { saturated fatty acids }\end{array}$ \\
\hline PUFA & polyunsaturated fatty acids \\
\hline RDA & recommended dietary allowances \\
\hline SES & socio-economic status \\
\hline SFA & saturated fatty acids \\
\hline UNICEF & United Nations Children's Fund \\
\hline WHO & World Health Organization \\
\hline
\end{tabular}





\section{Introduction}

\section{Rationale}

In the first half of the twentieth century progress in nutritional science can be characterized by the identification and elucidation of the role of vitamins, minerals and trace elements, and consequently adequacy resulted in the prevention of nutrient deficiency diseases. In recent decades evidence has accumulated for an important role of the diet in the development of chronic discases such as coronary heart disease. cancer, diabetes, osteoporosis and dental carics (1 4). Thu'se health and disease conditions are usually associated with food patterns that are prevalent in sedentary populations living in affluence, such as excess energy intake in general, and a high fat intake in particular. It is inferred that changing these patterns will offer the opportunity to reduce the incidence or severity of these diseases. Changing food habits is usually the cornerstone of a prevention-oriented food policy.

During the past two decades nutritional assessment has become an important topic on the health policy agenda in many (industrialized) countrics. For an effuctive and efficient pelicy, information on (changes in) food consumption is needed which may be obtained in nutrition surveillance (5,6). In 1978, the Dutch Minister of Health requested the Netherlands Nutrition Council to formulate recommendations on dietary patterns that could have a positive effect on public health status. A systematic evaluation of the relationship between diet and health, prevailing dietary habits and the nutritional status of the population was deemed necessary but was lacking so far. Until 1986, only an incomplete picture of dietary habits in the Netherlands was available (7). Since 1950, annual information about national food availability has been collected by the Agricultural Economics Research Institute (LEI) through food balance sheets, providing general information on the foods and nutrients available to the population (8). In addition, a nationwide household budget survey provided information on food expenditure. However, both information sources do not refer to actual food consumption and carry many pitfalls, such that rather crude assumptions have to be made to arrive at an estimate of average per capita consumption figures. Another drawback of the aforementioned data sources: is the lack of information on within- and between-person variation. The Nutrition Council advised to organize large-scale food consumption surveys un a rigular basis, and to complement this with information on the nutritional status (and lood consumption if needed) of special groups (9). The first Dutch National Food Consumption Survey (DNFCS) was carried out in 1987-1988 (10) and repeated in 1992. The resulting data can be used to address many policy-and science-oriented 
questions. The DNFCS is conducted to provide data on mean food and nutrient intake and their distribution over various categories of the population.

In (industrialized) countries dietary pattern may vary widely within and among individuals. To develop national nutrition policies, it is necessary to know to what extent the diet of various groups of the population is in accordance with the present guidelines and recommendations, and which segments of the population may be at risk (risk groups) of underconsumption (e.g. of micronutrients) or overconsumption (e.g. of fat, cholesterol). Data of national surveys are of great assistance in evaluating intakes, and a number of countries have conducted surveys within the framework of nutritional surveillance (11-21). The question whether recommendations for lifestyle changes such as nutrition should be aimed uniformly at the population at large or at high-risk groups has been a subject of recurrent debate (22), and is within the scope of such an evaluation. Subgroups may differ substantially from the overall population, so that such measures as nutrition education may be targeted on these groups.

In identifying risk groups it is important to realize that dietary patterns are complex $(23,24)$. In the Netherlands, one of the general guidelines for a healthy diet is that individuals should have a varied diet (25). More variety in food consumption is supposed to improve nutritional adequacy, but studies indicate that the effects may differ among nutrients and depend on the way the consumer interprets 'variety' $(26,27)$. Moreover, for risk group assessment one should be aware of the synergistic impact on health of an (un)favourable diet and other life-style factors, such as smoking and physical (in)activity (28-33). Dietary factors are often mutually interrelated due to the composition of foodstuffs and the combination of products as consumed. Studying these interrelationships through usage of different segmentation techniques can broaden the insight into differences in nutritional risks among subgroups of the population and will contribute to a better understanding of the complexity of dietary patterns. Knowledge of variety and of existing interrelationships can be valuable for risk group identification and is essential for decisions as to whether a population-based approach or a high-risk approach is advisable as a strategy for life-style changes.

The objectives underlying the studies described in this thesis were to investigate and evaluate the dietary patterns of the Dutch population, to identify risk groups, and to study the impact of several life-style and sociodemographic factors (and their interdependences) on dietary intake patterns, using the data of the 1987-1988 DNFCS.

In summary, the studies presented in this thesis were conducted to investigate the following questions:

- Is the Dutch Nutritional Surveillance System in line with other systems in industrialized countries?

- Is the Dutch diet generally in accordance with the guidelines of a healthy diet? 
- Is the slogan 'Eat a variety of foods' conducive towards a more adequate diet? - Is it possible to identify sociodemographic groups in which (un)desirable life-style factors (including diet) are interrelated?

- Is it possible to identify groups in which (un)favourable dietary factors cluster?

\section{Outline of the thesis}

Chapter 2 of this thesis describes the scope of nutritional surveillance in industrialized countries. The aim of nutritional surveillance, the sources of information needed for the study of specific purposes, risk groups and risk areas and some trends in nutritional surveillance are reviewed. In Chapter 3 the design and methods of the DNFCS are presented and some results are discussed.

Chapter 4 deals with a comparison of observed dietary intake data with the Dutch guidelines for a healthy diet. Since methods to assess food consumption and alcohol intake might be confounding factors in dietary risk assessment, special attention has been paid to the influence of these potential pitfalls in dietary evaluation.

Differences in dietary intake among adults across social classes and the association of some life-style factors with current socio-economic variables, using an a priori segmentation, are presented in Chapter 5. In Chapter 6 the question whether dietary factors cluster in an (un)desirable way is treated on the basis of a post-hoc segmentation technique.

The association of food variety and nutritional adequacy is described in Chapter 7. Finally, in Chapter 8 methodological issues pertaining to this study and some practical implications are discussed.

\section{References}

1. Surgeon Generai. Report on Nutrition and Health. US Department of Health and Human Services. Washington DC: Public Health Service. DHHS (PISS) Publication No 88-502010. 1988.

2. National Research Council. Diet and Health: Implications for reducing Chronic Disease Risk. Washington. DC: National Academic Press, 1989.

3. World Health Organization. Diet, Nutrition and the Prevention of Chronic Diseases. Report of a WHO Study Group. Geneva: World Health Organization, technical report Series 797, 1990.

4. Berkman LF. Breslow L. Health and way of living. The Alameda County Study. Oxford/New York: Oxford Univ. Press. 1983

5. World Health Organization. Health monitoring in the prevention of disease by environmental factors. Geneva: Pub. no. PEP/89.23, 1989

6. Kohlmeier L, Helsing E. Kelly A. Moreiras-Varela O, Trichopoulou A, Wotecki CE, Buss DH. Callmer E, Hermus RJJ. Sznajal J. Nutritional surveillance as the back bone of national nutrition policy: recommendations of the IUNS committee on nutritional surveillance and programme evaluation in developed countries. Eur J Clin Nutr 1990:44: 771-781. 
7. Löwik MRH, Hermus RJJ. The Dutch nutrition surveillance system. Food Policy $1988 ; 13: 359-365$.

8. Godeschalk FE. Consumptie van voedingsmiddelen in Nederland in 1986 en 1987. Periodic Report No 64-86/87. Den Haag: Agriculture Economics Research Institute (LEI). 1989.

9. Voedingsraad. Mogelijkheden tot het opzetten van een Voedingspeilingssysteem in Nederland. Voeding 1987:48:35-43.

10. Anonymous. Wat eet Nederland. Rijswijk: Ministerie van Welzijn, Volksgezondheid en Cultuur en Ministerie van Landbouw en Visserij. 1988.

11. Barker ME, McClean Si, McKenna PG, Reid NG, Strain JJ, Thompson KA, Williamson AP. Wright ME. Diet, lifestyle and health in Northern Ireland. Coleraine Univ. of Ulster, 1988.

12. Becker W. Kostvanornai södra Sverige-resultat fran en provundersökning. Vår Föda 1990;6: 322-333.

13. Cashel K. English R, Bennett S. Berzins J. Brown G. Magnus P. National dietary survey of adults: 1983. No. 1: Foods consumed. Canberra: Australian Government Publishing Service, 1983.

14. English R. Cashel K. L.ewis J, Bennett S, Berzins J, Penm R. National dietary survey of schoolchildren (aged 10-15 years): 1985. No. 1: Foods consumed. Canberra:

Australian Government Publishing Service, 1988.

15. Goncalves Ferreira FA. Amorim Cruz JA. Rego de Aquiar LA. Martins l. Carlota Mano M. Ascensao Dantas M. Inquérito alimentar national 1980 (1.a Parte).

Revista do Centro de Estudos de Nutricão 1985;9: 5-124.

16. Gregory J. Foster K. Tyler H, Wiseman $\mathrm{M}$. The dietary and nutritional survey of British Adults. London: HSMO, 1990.

17. Haraldsdóttir J. Holm L. Højmark Jensen J. Møller A. Danskernes Kostvaner 1985 1. Hovedresultater. Søborg: Miljøministeriet Levnedsmiddelstryrelsen, Publikation nr. 136. 1986.

18. Health and Welfare Canada. Nutrition Canada National Survey. Ottawa: Supply and scivices, 2973 .

19. Heseker H. Adolf T. Eberhardt W. Hartmann S. Herwig A. Kübler W. Matiaske B. Mock KJ, Schneider R, Zipp A. Lebensmittel- und Nährstoffaufnahme Erwachsener in der Bundesrepublik Deutschland. VERA-Schriftenreihe. Band III. Niederkleen: Wissenschaftlicher Fachverlag Dr Fleck, 1992.

20. Kornitzer M. Dramaix M. The Belgian interuniversity research on Nutrition and Health (BIRNH): General introduction. Acta Cardiologica 1989:44: 89-.99.

21. Nutrition Monitoring in the United States. An updating report in nutrition monitoring. Life Science Research Office FASEB. DHHS Publication No. (PHS) 89-1255. Hyattsville 1989.

22. Crouse JR. Gender, lipoproteins and cardiovascular risk. Lancet 1989:i: 318-320.

23. Axelson ML. The impact of culture on food-related behavior. Annu Rev Nutr 1986:6: $345-363$.

24. Waslien CJ. Factors affecting food selection in the American diet. Adv Food Res 1988:32:239-269.

25. Netherlands Nutrition Council. Guidelines for a Healthy Diel. The Hague: Voedingsraad, 1986.

26. Randall E, Nichaman MZ, Contant CF. Diet diversity and nutrient intake. J Am Diet Assoc 1985:85: 830-836.

27. Smiciklas-Wright. Krebs-Smith SM. Krebs-Smith J. Variety in foods. In: What is America eating. Washington DC: National Academic Press, 1986:126-140.

28. Belloc NB. Breslow L. Relationship of health status and health-related practices. Am J Epidemiol 1982:116: 765-775.

29. Cummings RO, Shaper AG. Walker M. Wale CJ. Smoking and drinking by middleaged British men: effects of social class and town of residence. $\mathrm{Br}$ Med $\mathbf{J}$ 1981:283: $1497-1502$. 
30. Baecke JAH, Burema J, Frijters JER, Hautvast JGAJ, Wiel-Wetzels WAM van der. Obesity in young Dutch adults. II Daily life-style and body mass index. Int J Obesity 1983:7: 13-24.

31. Jacobsen BK. Thelle DS. The Tromso Heart Study: food habits, serum cholesterol, HDL cholesterol and triglycerides. Am J Epidemiol 1987; 125: 622-630.

32. Solvoll K, Selmer K, Løken EB, Foss OP, Trygg K. Coffee, dietary habits, and serum cholesterol among men and women 35-49 years of age. Am J Epidemiol 1989;129: 1277-1288.

33. Puccio EM, McPhillips JB, Barrett-Connor E, Ganiats TM. Clustering of atheriogenic behaviors in coffee drinkers. Am J Public Health 1990;80: 1310-1313. 



\title{
Nutritional surveillance in industrialized countries
}

\author{
K.F.A.M. Hulshof, M.R.H. Löwik
}

\section{Introduction}

During the past two decades evidence has accumulated that prevailing dietary patterns have adverse health effects. Nutritional assessment has become an important topic on the health policy agenda. This paper describes the aim of nutritional surveillance, the availability and uscfulness of nutritional surveillance indicators (specially food consumption), and some trends, risk groups and risk arcas. Nutrition-related health problems and surveillance systems differ among countric's, in particular between developed and developing ones. Therefore, this article deals only with industrialized countries in Europe and Australia, Canada and the USA.

\section{Aim of nutritional surveillance}

As stated by a Joint FAO/UNICEF/WHO Expert Committee, the objectives of nutritional surveillance are as follows: to describe the nutritional status of the population, with particular reference to groups at risk; to contribute to the analysis of causes for changes and differences; to promote decisions by governments on food and nutrition policy issues; to predict future trends and to evaluate the effects of nutritional programmes.

As illustrated in Fig. 2.1, nutritional surveillance ideally provides information on a wide range of variables, from food availability, distribution and consumption and nutrient utilization (as reflected in nutritional status) to, ultimately, health status and mortality. This results in identification of public health problems that call for specific action and lead to nutrition research priorities (both applied and more fundamental). The data can be obtained from either existing sources, including administrative data, or surveys undertaken specially for surveillance purposes.

\section{Sources of dietary information}

Insight into dietary patterns is a core target of nutritional surveillance since this provides a comprehensive basis for nutritional risk assessment. In principle, three different types of data can be used: food supply data, data from household 


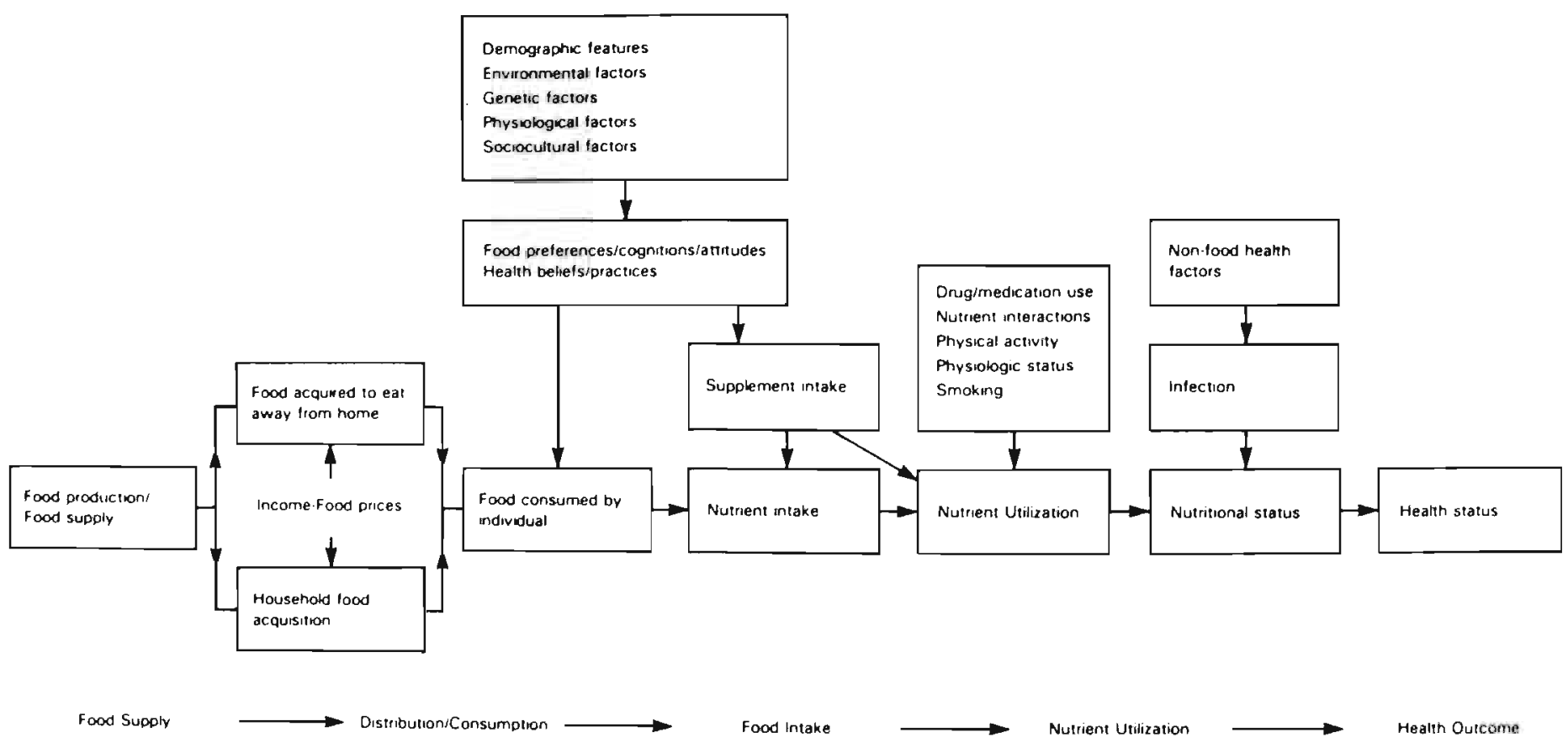

Fig. 2.1. A conceptual model of the relationships of food to health. Source: Life Sciences Research Office, FASEB (1989). 
consumption surveys, and data from dietary surveys among individuals. Each type of data corresponds with a different stage in the food distribution chain and is obtained by different methods.

\section{Food supply data}

Food supply data provide information on the type and amount of food available for human consumption, to the country as a whole. The supply is calculated in food balance sheets (FBSs) which are an account, on a national level, of the annual production of food, changes in stocks, imports and exports, and agricultural and industrial use. Food supply is usually expressed per head of the population in kilograms per year or grams per day. Per capita consumption of energy and some additional nutrients is calculated using food composition tables.

Food supply data refer to food availability, which gives only a crude impression of potential consumption. Food and nutrient losses prior to consumption, due to processing, spoilage, trimming and waste, may not be adequately accounted for. Furthermore, these data provide no information about the distribution of food among population groups or districts.

International FBSs are prepared and published by both the Food and Agriculture Organization of the United Nations (FAO), the Organization for Economic Cooperation and Development (OECD) and the statistical office of the commission of the European Communities (EUROSTAT). FAO has published FBSs since 1949, also covering the period 1934-1948. Since 1949. FBSs have been compiled on an annual basis from data supplied by about 200 countries. Information is available for all European countries, Australia, Canada, Japan, New Zealand and the USA. Since 1971, FAO has included its FBS data in the Interlinked Computer Storage and Processing System of Food and Agricultural Commodity Data (ICS). The OECD FBSs cover 23 countries, i.e. 18 European countries, Australia, Canada, Japan, New Zealand and the USA. The EUROSTAT publish FBSs for its 12 member countries. Although FBSs are compiled in a similar way, they differ in coverage, food grouping and level of processing of commodities (e.g. FAO lists 300 food items classified into 17 food group categories, OECD 70 items in 13 categories) and in nutrient conversion factors. FAO and OECD usually publish summaries of FBSs every 3-5 years, with a time-lag of 3-4 years between data collection and publication. The ICS supplies more up-to-date figures both on magnetic tape and on floppy disk. EUROSTAT publish supply balance sheets in the Agricultural Statistical Yearbook.

In addition to the international FBSs, many countries publish national FBSs, mostly in statistical yearbooks or special statistical publications. For instance, US food supply statistics are available since 1909 , and in the Netherlands FBSs are available since 1950, both on an annual basis. National FBSs tend to be more up-todate and are normally available annually, again with a time-lag of up to 3 years. 
Owing to different methods for compilation and presentation, these data can differ from the international FBSs.

Despite their limitations, FBSs are useful in that they indicate the (in)adequate aspects of food supply, provide material for planning food supply (production, imports and exports) and give crude indications of (un)desirable changes in terms of expected health impact. As a result of their long history, FBSs are especially useful for assessing trends over time. In contrast with national FBSs, the international FBSs can be used for comparative studies, provided that the FAO and OECD data sets are not mixed up. Figure 2.2 illustrates the use of FBS data (FAO) for comparisons across countries and for trends over time. This figure shows the consumption of meat and meat products in five selected countries. Only in the UK has the consumption of meat and meat products remained remarkably steady since the 1960s. In the other countries the total consumption of meat has increased considerably, especially in Spain. The same tendency has been observed in other southern European countries and reflects one of the important changes in the Mediterranean diet over the past decades. Such comparisons implicitly assume that the demographic changes across the countries are similar.

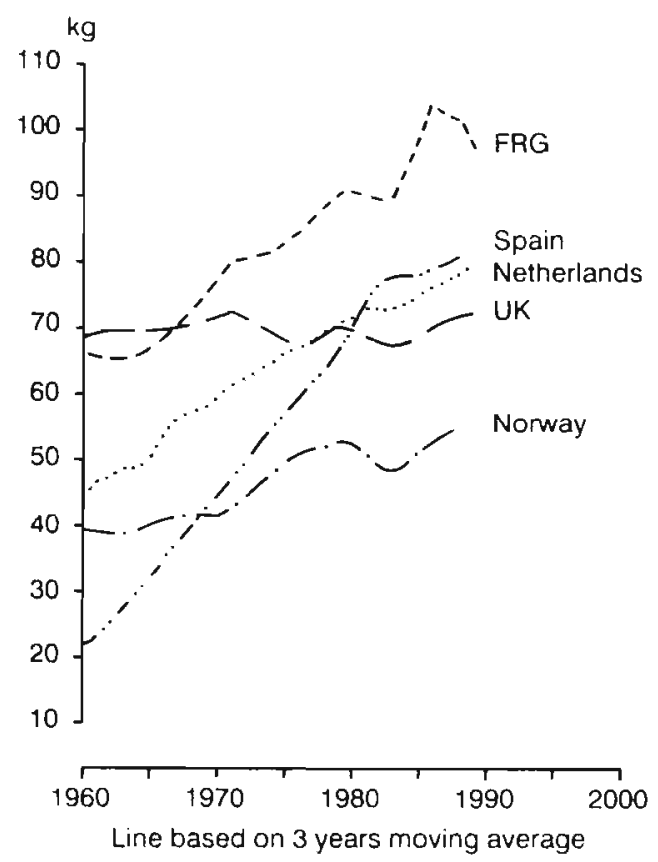

Fig. 2.2. Available consumption of meat and meat products ( $\mathrm{kg}$ per head per year) in five European Countries. Source: Food and Health Indicators in Europe, Copenhagen, WHO Regional Office for Europe 1990 (computer program based on FAO and WHO databases. 
Food available at the household level may be estimated by budget surveys and by consumption surveys. The first type of survey gives infornation on the purchases of food in terms of expenditure, used in economic policy. For instance, weights for the construction of consumer price indices can be calculated. In household consumption surveys the amounts of foods and drinks brought into the household are also recorded. For the most part, only the expenditures of meals taken outdoors are noted. Some household surveys may even measure changes in food stocks, in addition to acquisition.

In general, household surveys do not provide information on how food is handled within the household, or on actual consumption by its members. Sometimes, the consumption data are converted to individual intake levels. The methods vary from simply dividing the total consumption by the number of people in the households to assigning factors (consumer units) to persons weighed according to age and sex. In most countries, household surveys have started in the 1940s or 1950 s. Only very few countries have a continuous system, some repeat surveys every 3-4 years, others only every 5-10 years. In the Netherlands, the household budget surveys started in 1951, and since 1978 they have been conducted annually. In Europe, the best-known study is the specialized and ongoing household food consumption survey of the UK. Australia, Canada and Japan have regularly conducted household consumption surveys. In the USA, the first national household food consumption survey was conducted in 1936-1937. Between 1942 and 1965, four nationwide studies on household consumption were carried out. Since 1965, US household food consumption surveys also provide information of food intake on the individual level of the houschold members. At present, a wide range of data on household surveys are available, as shown in the FAO Food and Nutrition Policy Papers and a recent WHO publication. However, since the dietary data are based on a variety of methods, the surveys are not very suitable for comparisons among countries. Differences exist in sampling procedures, food grouping, conversion to nutrients and period, frequency and technique of data collection. For example, sample sizes vary from less than 500 households (Switzerland) to over 30000 (Italy and FRG), which is only partially explained by population size. Snacks, sweets, soft drinks and alcoholic beverages are excluded from some surveys. Data on the quantity of and/or expenditure on food may be collected by record-keeping, by interviews or by both methods. Household accounts for non-food items can cover a period of 4 weeks, but for foodstuffs 2 weeks is more usual.

In contrast to FBSs, household surveys can supply information on food (and nutrient) patterns in subgroups of households. These groups may be classified by economic, demographic and other factors, which provides the opportunity for risk group identification. The results of household surveys play an important role in nutritional surveillance within countries, particularly when surveys are carried out annually, which reveals trends in food consumption. For international comparison 
these data are of limited value, and harmonization of data collection and presentation is needed.

\section{Individual dietary surveys}

In contrast to FBSs and household surveys, data from individual dietary surveys provide information on average food and nutrient intake and their distribution over various well-defined groups of individuals. Data more closely reflect actual consumption and can provide additional information on meal patterns etc.

To collect dietary intake data on an individual level, several methods can be used. Briefly, the methods can be divided into two categories, record and recall methods. Record methods collect information on current intake, keeping a record of all foods and drinks based on menu, household measures and/or weighing, over one or more days. Recall methods reflect past consumption, varying from intake over the previous day (24-h recall) to usual food intake (dietary history or food frequency). Each form has its own strengths and weaknesses, and there is no single ideal method. Details of the available methods for assessing food consumption of individuals are given in numerous reviews and manuals (e.g. Bingham, 1987).

To characterize the average intake of food and nutrients and their distribution over various groups of individuals, a 24-h recall or 1-day food record is appropriate, provided the sample is representative of the population under study, and day-of-theweek and seasonal variations are taken into account. To determine the proportion 'at risk' for inadequate intake, the food consumption of each subject must be measured over more than one day, or retrospective information on intake over a longer period may be used (c.g. dietary history method). The appropriate period depends on the purposc of making an estimate, the precision desired, the food component(s) of interest, the intra- and interindividual variation components and the period over which an intake has to be low or high before health risks are introduced.

Most industrialized countries, if not all, have carried out small-scale dietary surveys. These surveys provide valuable information, but owing to samples of convenience and different food consumption methods their usage in national nutrition policy and nutritional surveillance is of limited value. The number of countries that have conducted individual dietary surveys within the framework of nutritional surveillance is relatively low. It appears that Australia, Canada, the USA and several European countries (Belgium, Denmark, FRG, Ireland. Netherlands, Portugal. Sweden. UK) have performed individual nutritional surveys on a national basis. Although some surveys are planned to be repeated, until now the majority of the surveys have been conducted only once. Table 2.1 presents examples of national surveys. These surveys differ in coverage of population, methods used to collect dietary data, nutrition-related health indices. etc. In several countries dietary data were collected using a record method, but the number of record days varied from 1 to 7. A 7-day weighed record is thought to be the most accurate method of dietary 
Table 2. 1. Nationwide food consumption surveys with individual data.

\begin{tabular}{|c|c|c|c|c|c|c|c|c|c|}
\hline \multirow[t]{2}{*}{ Country } & \multirow[t]{2}{*}{ Period } & \multirow[t]{2}{*}{ Survey } & \multicolumn{2}{|c|}{ Population } & \multirow{2}{*}{$\begin{array}{l}\text { Sample } \\
\text { size }\end{array}$} & \multirow{2}{*}{$\begin{array}{l}\text { Response } \\
\text { rate }(\%)\end{array}$} & \multirow{2}{*}{$\begin{array}{l}\text { Dietary } \\
\text { method }^{2}\end{array}$} & \multirow{2}{*}{$\begin{array}{l}\text { Dietary } \\
\text { data }^{3}\end{array}$} & \multirow[t]{2}{*}{ Other information ${ }^{4}$} \\
\hline & & & $\operatorname{sen} x^{5}$ & age & & & & & \\
\hline \multirow[t]{2}{*}{ Australia } & 1983 & National Dietary Survey of adults ${ }^{6}$ & $M+F$ & $25-64$ & 6255 & 75 & $24 \mathrm{~h} \mathrm{RI}$ & F. N & A, BP, BC, HM, PE, PA \\
\hline & 1985 & National Dietary Survey of School Children ${ }^{7}$ & $M+F$ & $10-15$ & 5224 & 65 & 1d Rd & F. N & $\mathrm{A}, \mathrm{BP}, \mathrm{BC}, \mathrm{HM}, \mathrm{PE}, \mathrm{PA}$ \\
\hline Belgium & $80-85$ & Nutrition and Health (BIRNH) & $M+F$ & $25-74$ & 11076 & 37 & Id Rd & $\mathrm{F}, \mathrm{N}$ & $\mathrm{A}, \mathrm{BP}, \mathrm{BC}, \mathrm{MH}$ \\
\hline Canada & $70-72$ & Nutrition Canada & $M+F$ & $0-65+$ & 12795 & 47 & 24h Rl,FF & $\mathrm{F}, \mathrm{N}$ & A, DE, HM, BC, MH, ME \\
\hline Denmark & 1985 & Dietary Habits in Denmark & $M+F$ & $15-80$ & 2242 & NA & $\mathrm{DH}$ & F.N & A \\
\hline Germany & $85-89$ & National Nutrition Survey & $M+F$ & $4-65+$ & $\begin{array}{l}24632 \mathrm{i} \\
11141 \mathrm{~h}\end{array}$ & 71 & $7 \mathrm{~d} R \mathrm{R}$ & $\mathrm{F}, \mathrm{N}$ & $\begin{array}{l}\text { A, BC, HM, PE }(n=2000 \geq 18 \mathrm{yr}) \\
\mathrm{NK} \text { Ait }(n=11141 \geq 14 \mathrm{yr})\end{array}$ \\
\hline Ireland & 1990 & Irish National Nutrition Survey & $M+F$ & $10.65+$ & 1214 & NA & $\mathrm{DH}$ & $\mathrm{F}, \mathrm{N}$ & NA \\
\hline Netherlands & $87-88$ & $\begin{array}{l}\text { Dutch National Food Consumption } \\
\text { Survey (DNFCS) }\end{array}$ & $M+F$ & $16-64$ & $\begin{array}{r}5898 \mathrm{i} \\
2203 \mathrm{~h}\end{array}$ & $\begin{array}{l}81 \\
79\end{array}$ & $2 \mathrm{~d} \mathrm{Rd}$ & F. N & A (self-reported data) \\
\hline Porlugal & 1980 & Portuguese Food Consumption Survey & $M+F$ & $0-65+$ & 13000 & 72 & $\begin{array}{l}\text { Id Rd } \\
24 \mathrm{~h} \text { RI,FF }\end{array}$ & $F, N$ & A. BP, BC, HM, MH \\
\hline Sweden & 1984 & Houschold Food Survey & $M+F$ & $0-74$ & 3000 & 70 & $7 \mathrm{~d} \mathrm{Rd}$ & $F, N$ & $\mathrm{~A}, \mathrm{PA}$ \\
\hline \multirow[t]{2}{*}{ UK } & $86-87$ & $\begin{array}{l}\text { Dietary and Nutrional Survey of } \\
\text { British Adults }\end{array}$ & $M+F$ & $16-64$ & $\begin{array}{l}2197 \mathrm{i} \\
2197 \mathrm{~h}\end{array}$ & 70 & 7d Rd & $\mathrm{F}, \mathrm{N}$ & $A, B P, B C(\geq 18 \mathrm{yr}), \mathrm{HM}(\geq 18 \mathrm{yr})$ \\
\hline & $86-87$ & $\begin{array}{l}\text { Dict. Life-Style \& Health in Northern } \\
\text { Ireland }\end{array}$ & $M+F$ & $16-64$ & 616 & NA & $7 \mathrm{~d} R \mathrm{~d}$ & $\mathrm{~F}, \mathrm{~N}$ & $\mathrm{~A}, \mathrm{BP}, \mathrm{BC}, \mathrm{HM}, \mathrm{MH}, \mathrm{PA}$ \\
\hline \multirow[t]{7}{*}{ USA } & $71-74$ & $\begin{array}{l}\text { National Health and Nutritional } \\
\text { Examination Surveys (NHANES) }\end{array}$ & $M+F$ & $1-74$ & 20749 & 74 & $24 \mathrm{~h} \mathrm{RI}, \mathrm{FF}$ & $\mathrm{F}, \mathrm{N}$ & A, HM, BC. PE, MH \\
\hline & $76-80$ & NHANES II & $M+F$ & $1 / 2-74$ & 20322 & 73 & 24h RI, FF & $\mathrm{F}, \mathrm{N}$ & A, HM, BC, PE, MH \\
\hline & $88-94$ & NHANES III & $M+F$ & $\geq 2 \mathrm{mo}$ & $\begin{array}{l}40000 \\
\text { planned }\end{array}$ & NA & $24 \mathrm{~h} \mathrm{RI}, \mathrm{FF}$ & F. N & $A, D E, H M, B C, P E$ \\
\hline & $77-78$ & $\begin{array}{l}\text { Nationwide Food Consumption Survey } \\
\text { (NFCS) }\end{array}$ & $M+F$ & all ages & $\begin{array}{l}30770 \mathrm{i} \\
14930 \mathrm{~h}\end{array}$ & $\begin{array}{l}70 \\
61\end{array}$ & $\begin{array}{l}24 \mathrm{~h} \mathrm{Rl} \\
+2 \mathrm{~d} \mathrm{Rd}\end{array}$ & $F, N$ & \\
\hline & $87-88$ & $\begin{array}{l}\text { Nationwide Food Consumption Survey } \\
\text { (NFCS) }\end{array}$ & $M+F$ & all ages & $\begin{array}{c}25100 \mathrm{i} \\
9600 \mathrm{~h} \\
\text { (target) }\end{array}$ & NA & $\begin{array}{l}24 \mathrm{hRl} \\
+2 \mathrm{~d} R \mathrm{Rd}\end{array}$ & $F, N$ & \\
\hline & $85-86$ & $\begin{array}{l}\text { Continuing Survey of Food Intakes } \\
\text { by Individuals (CSFII) }\end{array}$ & $\begin{array}{l}F \\
M+F \\
M\end{array}$ & $\begin{array}{l}19-50 \\
1-5 \\
19-50\end{array}$ & $\begin{array}{r}2784 \\
996 \\
635\end{array}$ & & $\begin{array}{l}24 \mathrm{~h} \mathrm{R} R \\
24 h R^{\beta} \\
24 \mathrm{~h} \mathrm{Rl}\end{array}$ & F. $\mathrm{N}$ & \\
\hline & $89-96$ & $\begin{array}{l}\text { Continuing Survey of Food Intakes } \\
\text { by Individuals (CSFII) }\end{array}$ & $M+F$ & all ages & NA & NA & $\begin{array}{l}24 \mathrm{~h} R \mathrm{l} \\
+2 \mathrm{~d} R \mathrm{~d}\end{array}$ & $F, N$ & \\
\hline
\end{tabular}

$\mathrm{I}_{\mathrm{i}}$ individuats; $\mathrm{h}$, households; ${ }^{2}$ information other than sociodemographic and other background data: $\mathrm{R}$, recall: $\mathrm{Rd}$, record. $\mathrm{FF}$, fond frequency; $\mathrm{DH}$, dietary history; ${ }^{3} \mathrm{~F}$, food groups; $\mathrm{N}$, nutrients; ${ }^{4} \mathrm{~A}$. anthropometry; BP. blood pressure; BM. biochemical tests: HM, haematological tests; PE. physical examination; $\mathrm{MH}$, medical history; DE, dental examination; PA, 
assessment. However, this method has a high respondent burden, which can have consequences for the response rate and representativeness of the sample. Response rates vary widely. Sometimes, weighing factors are used to adjust for sources of nonresponse. Most surveys focus on the general population. Some subgroups (such as ethnic minorities, pregnant or lactating women) do not occur in the population in sufficient numbers to appear in the survey sample with sufficient representation to allow of reliable estimates of their diet and nutritional status. Oversampling can improve the precision of estimates in nutritional assessment in specific groups, and is used in several surveys, including those in the USA. Special (vulnerable) groups can also be examined in separate studies. For example, nationwide surveys based on random sampling of an elderly population are conducted in the Australia, the Netherlands, Sweden, UK and the USA (not included in Table 2.1).

\section{Nutritional status and health indices}

The assessment of nutritional status includes, in addition to dietary intake, indicators of nutrition-related health status, such as anthropometric measurements, haematological and biochemical tests, clinical signs of deficiencies, and risk factors for diseases associated with diet (e.g. high blood pressure and overweight). Furthermore, determinants of food- and health-related behaviour, such as nutritional knowledge and attitudes, may be studied. These indicators can be included in the surveys or studied in separate samples. As shown in Table 2.1, most national surveys studied both dietary patterns and nutrition-related health status indicators. Nutritional surveillance in the USA has a long tradition and its surveys can be considered the most comprehensive in the world. For brevity, this paper reports only a part of its activities.

A major advantage of having comprehensive (broadly oriented) information at the individual level is that interrelationships can be studied. In studying correlations between diet and nutritional status indicators, one of the characteristics of a crosssectional study is that mostly low correlations are found. This is attributable to, among other things, intraindividual variation and inaccurate assessment of intake and status indicators. In a cross-sectional design, the observation that a particular dietary factor is positively or inversely associated with a relevant variable is meaningful, even when there is a low $P$ value, since this provides suggestive evidence for diet-health relationships which should be studied in more detail. To establish a causal link between diet and health, both intervention and (semi-) longitudinal studies are necessary. End-points, such as morbidity and mortality data, provide very valuable additional information on the role of nutritional factors in diseases. 


\section{Risk areas and risk groups}

Nutritional assessment includes a normative evaluation of dietary intake and nutritional status indicators in order to estimate the proportion of the population at risk. Nutritional status indices can be evaluated by comparing them with reference values mostly obtained from healthy adults. Alternatively, predetermined cut-off points (based on consensus reports) can be used. In evaluating dietary intake the reference values applied in recommended dietary allowances (RDAs) or dietary guidelines are often used. However, cut-off values are prone to some misclassification owing to (biological) variation within and among individuals. Estimates of prevalence values can be adjusted for within-person variation by statistical procedures. Despite the weaknesses of cut-off points, these criteria are commonly used and very often needed to evaluate dietary intake as well as nutritional status parameters.

In most industrialized countries the principal nutrition-related health problems are related to overconsumption of some nutrients, particularly energy, fat. saturated fatty acids, cholesterol, sodium and alcohol. Although mean intake of energy among adults is mostly lower than recommended, the data available from nutritional surveillance indicate a high prevalence of overweight in several countries. In many subjects intake levels of total fat, saturated fatty acids and cholesterol are too high, leading to an increase in average serum cholesterol levels. The prevalence of hypertension, for which mineral intake and alcohol consumption may be relevant factors, is high in most adult groups. Table 2.2 gives an example of the prevalence estimates of obesity, hypercholesterolaemia and hypertension, as found in some of the studies mentioned. Since the age range covered in the surveys varied, comparisons were restricted to the common age range of 25.4 ycars.

Table 2.2. Prevalence (\%) of overweight, obesity, hypercholesterolatmia and hypertension in adults aged 25-64 in Australia, the UK and the USA.

\begin{tabular}{|c|c|c|c|c|c|}
\hline Country & Sex & $\begin{array}{l}\text { Overweight } \\
\left.\text { (BMI }{ }^{1} 25-30\right)\end{array}$ & $\begin{array}{l}\text { Obesity } \\
(\text { BMI > 30) }\end{array}$ & $\begin{array}{l}\text { Serum cholesterol }{ }^{2} \\
(\geq 6.5 \mathrm{mmol} / 1)\end{array}$ & Hypertension ${ }^{3}$ \\
\hline Australia ${ }^{4}$ & $\begin{array}{l}M \\
F\end{array}$ & $\begin{array}{l}43^{5} \\
35\end{array}$ & $\begin{array}{l}7 \\
7\end{array}$ & $\begin{array}{l}19 \\
21\end{array}$ & $\begin{array}{l}17 \\
13\end{array}$ \\
\hline $\mathrm{UK}^{6}$ & $\begin{array}{l}\mathrm{M} \\
\mathrm{F}\end{array}$ & $\begin{array}{l}42 \\
25\end{array}$ & $\begin{array}{c}9 \\
13\end{array}$ & $\begin{array}{l}32 \\
29\end{array}$ & $\begin{array}{l}\mathrm{NA}^{7} \\
\mathrm{NA}\end{array}$ \\
\hline $\mathrm{USA}^{8}$ & $\begin{array}{l}\mathrm{M} \\
\mathrm{F}\end{array}$ & $\begin{array}{l}44 \\
28\end{array}$ & $\begin{array}{l}13 \\
17\end{array}$ & $\begin{array}{l}21 \\
23\end{array}$ & $\begin{array}{l}18 \\
15\end{array}$ \\
\hline
\end{tabular}

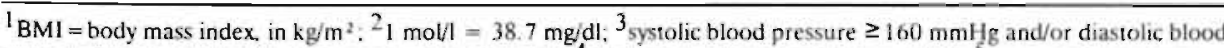
pressure $\geq 90 \mathrm{mmHg}$ and/or treatment of hypentension: ${ }^{4}$ Risk Factor Prevalence Study. 1983; ${ }^{5}$ overweight in women defined as BMI $24-30 \mathrm{~kg} / \mathrm{m}^{2} ;{ }^{6}$ Dietary and Nutritional Study of British Adults; ${ }^{7}$ ctata not available for comparisons:

${ }^{8}$ Second National Health and Nutrition. Examination Study (NHANES II), $1976-1980$.
} 
Although Table 2.2 can give only a rough impression (the periods in which the studies were conducted differed, exclusion criteria might vary, etc.) the proportion of subjects classified as having overweight is similar for all three countries. The exception is Australia with noticeably more overweight women, but this could in part be the consequence of different criteria. The prevalence of obesity was highest in the USA, the prevalence of hypercholesterolaemia was considerably higher in the UK, and the percentages of hypertensive subjects in Australia and the USA were comparable. Figures for hypertension were not available for the UK, since the Dietary and National Survey of British Adults only presented separate values for systolic, diastolic and the calculated mean blood pressure, and excluded subjects receiving treatment for hypertension.

In most countries, the average intake of most minerals and vitamins appears adequate for the population at large. In general, iron is an exception in that many subjects have a low iron intake relative to the RDAs. In most countries groups with a low intake are young children, adolescents and women of child-bearing age. The intake of vitamins (e.g. vitamin A and its precursors, vitamin B-6, vitamin C, folic acid) and minerals and trace elements (e.g. calcium, magnesium, zinc, iodine, fluoride) are considered to be potential risk factors in several countries. For instance, the high prevalence of low vitamin A levels in blood suggests that young children having parents with a low income are at risk in the USA; the prevalence of low plasma vitamin $\mathrm{C}$ levels is generally higher in groups with low socio-economic status and in smokers (several countries). These data show that evidence for nutritional risk obtained through biochemical data is essential for the assessment of risk areas and risk groups.

\section{Trends in nutritional surveillance}

Biochemical and clinical measurements can be used to study trends provided that the measurements are standardized over time. For example, this is the case for some indicators (such as overweight, hypertension, elevated serum cholesterol levels) in the USA. These data indicate a recent decline in the prevalence of hypertension and hypercholesterolaemia, but no decline in the prevalence of overweight.

Concerning dietary intake, almost all industrialized countries possess information on trends in food supply over time in the national diet. An example is presented in Fig. 2.2. In several countries, data suggest that some changes in dietary patterns are in agreement with current health recommendations, but there is still a substantial difference between the guidelines and actual consumption patterns in most countries.

Growing awareness about the potential relationships between diet (as life-style factor) and health is accompanied with an increasing demand of data at the individual level. The use of data of this type for trend analyses is hampered by the irregularity of data collection at the national level and/or by changes in survey methods over time. During the past decade, several countries (e.g. FRG, 
Netherlands and Sweden) have followed the example of the USA and collected individual dietary data using the framework of a household. This method of sampling and data collection has practical advantages, offers the opportunity to use the data at a household level and reduces costs. In the USA, there is a tendency to collect continuously data at an individual level between larger ten-yearly surveys. For most other countries a more regular collection of data and an integration of other appropriate data from existing information systems (e.g. census data) is of primary concern.

\section{Bibliography}

Becker W. Helsing E. Food and health data. Their use in nutrition policy making. Copenhagen: WHO Rcgional Publications, European Series No. 34,1991.

Bingham SA. The dietary assessment of individuals; methods, accuracy. new techniques and recommendations. Nutr Abstr Rev 1987; 57: 705-742.

FAO. Review of food consumption surveys. Rome: FAO, No. 1, 1977; 27, 1981; 35, 1985; $44,1988$.

Kelly A ed. Nutritional surveillance in Europe: a critical apraisal. Wageningen: Stichting Nederlands Instituut voor de Voeding. EURO-NUIT Report no. 9. 1987.

Life Sciences Research Office, Federation of American Societies for Experimental Biology. Nutrition Monitoring in the United States. An update report on nutrition monitoring. Hyattsville: Department of Health and Human Services. DHHS Publication No. (PHS) $89-1255,1989$.

WHO. Methodology of nutritional surveillance. Report of a Joint FAO/UNICEF/WHO Expert Committee. Geneva: WHO Technical Report Series No. 593. 1976. 



\title{
The Dutch National Food Consumption Survey: design, methods and first results
}

\author{
K.F.A.M. Hulshof and W.A. van Staveren
}

\begin{abstract}
The first Dutch National Food Consumption Survey (DNFCS) was conducted in 1987-88. This report describes the design and methods of the Dutch nutrition surveillance system. The rationale for the use of an existing panel and a two-day record is given, and some potential pitfalls are discussed. The DNFCS data are compared with data of the Dutch national food balance sheets. Data at both individual and household levels are presented and discussed. An example regarding risk group identification is given.
\end{abstract}

\section{Introduction}

A nutrition surveillance system has been set up to support implementation and evaluation of Dutch nutrition policies. According to recommendations of the Netherlands Nutrition Council such a system should consist of two components, namely monitoring of the Dutch population with regard to food availability and consumption, and investigations into the nutritional status (and, if necessary, food consumption) and health of specific vulnerable groups (1). The Dutch nutrition surveillance system has been described in detail elsewhere (2). The first provisional data of a large-scale food consumption survey conducted within the framework of this system have been published in Dutch in the booklet 'Wat eet Nederland' (3). This report describes the first DNFCS (4) and discusses its purpose, design, methods and some results. The results reported here illustrate how the data can be used at different aggregate levels.

In the Netherlands national food balance sheets (FBSs) and household budget surveys provide insight into trends at the national level but not into food consumption at an individual level. The latter type of information is needed for a wide range of purposes such as identification of groups within the population having unhealthy diets, the design and evaluation of nutritional education programmes on a national and regional basis, legislation with respect to enrichment or restoration of manufactured foods, the establishment of an acceptable daily intake of additives, and as a point of reference for small-scale studies of food consumption. The DNFCS 
Representative Probability Sample of Dutch Private Households

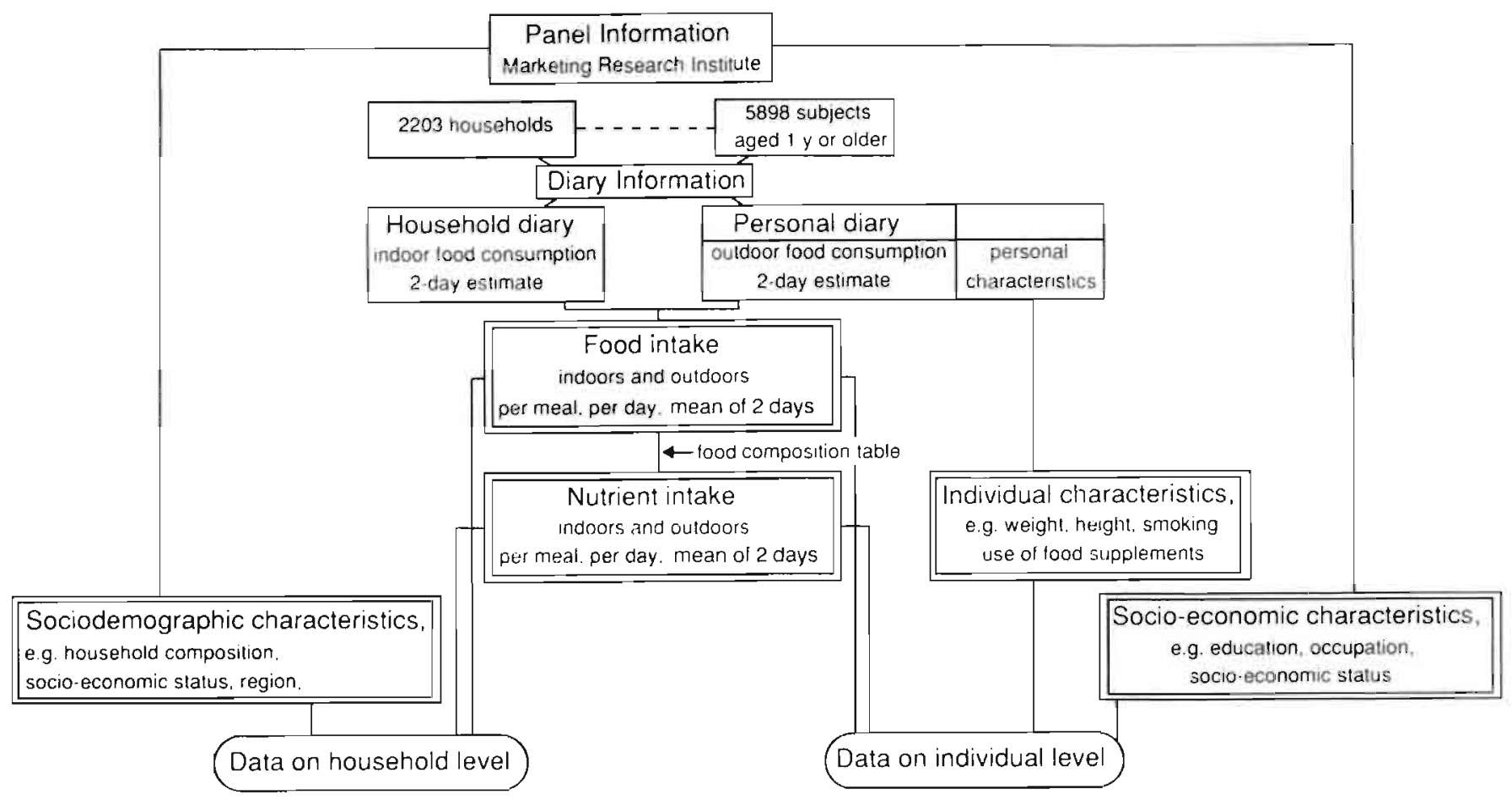

Fig. 3.1. Design of the first Dutch National Food Consumption Survey. 
is conducted to provide data on mean food and nutrient intake and their distribution over various categories of the population. The DNFCS is planned to be repeated at least once every five years to obtain information on trends in consumption patterns.

\section{Design and methods}

The first DNFCS was conducted by a marketing research institute experienced in nationwide surveys (AGB-Attwood) (5), in close cooperation with a steering committee of experts in food consumption studies. Data collection started in 1987 after the feasibility of the three-day record method and the field procedures had been tested in a pilot study. (Fig. 3.1 presents the design of the first DNFCS.)

\section{Sample selection}

The household was chosen as unit of observation; individual data are collected from household members aged 1 year and older. Households were preferred as observation units because sample selection and data collection take less time than in a random sample of a similar number of individuals. Furthermore, some of the collected data can be compared with the results of the household budget survey. Households have been defined as a group of persons independently living in the same dwelling and sharing common household food supply arrangements for at least four days a week. Single persons who were self-supporting with respect to food supply are defined as single houscholds. From an existing panel 2793 households were selected. This panel consisted of a stratified probability sample of noninstitutionalized households living in the Netherlands. Not eligible were: institutionalized subjects, households whose head housekeeper was aged 75 or over, and households whose members could not speak Dutch.

\section{Data collection}

Information on food intake was collected using a two-day record. Results of the pilot study indicated that a three-day record was too heavy a burden for most of the subjects. The survey was distributed equally over the seven days of the week, which facilitated assessment of effects of the day of the week, and over a whole year, from April 1987 to March 1988 (holiday periods excluded), so that seasonal effects were incorporated. In each household the person principally responsible for domestic affairs (the head housekeeper) was the most important informant and was visited on two occasions by one of 54 specially trained dietitians. During the first visit the fieldworker explained the household diary. In that diary all the food supplied by the main housekeeper to the members of that household was recorded. Precise descriptions of methods of cooking, recipes and ingredients were requested. The housekeeper also noted for each meal the persons (including visitors) attending and the type and quantities of food items served to them, as well as the amounts of leftovers and foods 
given to pets. In addition to a household diary, a diary was kept by each person to record food eaten out. The diaries of children below the age of 13 years were completed by (one of) their parents. During the second visit the interviewer checked the diary for completeness. Common household measures and foods regularly used were weighed.

\section{General questionnaire}

Demographic and socio-economic data were known to AGB Attwood. Additional data on body weight and height (both self-reported data), use of nutritional supplements, special dietary practices, smoking habits, meal patterns and sleeping hours were collected by a structured questionnaire included in the personal diary (Fig. 3.1).

\section{Data treatment}

For each individual the average intake over two days was derived from the household diary and the individual diary. These data were converted into energy and 28 nutrients with an extended computerized version of the Dutch food composition table of 1986/1987 (6,7). For minerals and vitamins the intake through nutritional supplements was not taken into account because (brand) labels and frequency of usage were not recorded with sufficient accuracy. The 883 food products used were categorized into 23 major food groups, classification being based on similarity in nutrient composition and/or origin.

\section{Results}

Of the 2793 households contacted 2203 agreed to participate, comprising 5898 persons. The response rate was $79 \%$ at a household level, and $81 \%$ at an individual level. The population structure of the subjects surveyed appeared to be comparable with the data obtained from the (Dutch) Central Bureau of Statistics (8).

\section{Comparison with data from the national food balance sheets}

Table 3.1 gives the mean and the standard deviation for the intake of energy and some selected nutrients for the total sample. The sources of energy showed a pattern typical of a Western diet. The absolute amounts were lower than the data on availability of energy and nutrients obtained from the FBSs in 1965, 1970, 1980 and 1986 (9). This is not surprising since FBSs include food purchased for pets and loss or wastage of food in the form of trimmings, spoilage or plate waste. The mean proportions of energy derived from fat, protein, carbohydrates and alcohol in the DNFCS differ only slightly from the FBS data. 
Table 3.1. Data collected by DNFCS ( $n=5898$ ) compared with the availability of energy and selected nutrients as determined by food balance sheets (FBSs).

\begin{tabular}{|c|c|c|c|c|c|}
\hline & \multicolumn{4}{|c|}{ FBSs, mean } & DNFCS, mean $\pm S D$ \\
\hline & 1965 & 1970 & 1980 & 1986 & $1987 / 1988$ \\
\hline Energy $(\mathrm{MJ} /$ day $)$ & 12.5 & 12.6 & 13.2 & 13.2 & \pm 3.1 \\
\hline $\begin{array}{l}\% \text { of energy derived from } \\
\text { fat }\end{array}$ & 39.1 & 38.7 & 38.0 & 38.8 & $40.0 \pm 7.2$ \\
\hline protein & 11.0 & 11.1 & 11.3 & 11.7 & $13.4 \pm 3.1$ \\
\hline carbohydrates & 47.9 & 47.4 & 46.3 & 45.4 & $43.9 \pm 8.1$ \\
\hline alcohol & 2 & 3 & 4 & 4 & $3 \pm 5$ \\
\hline Calcium (mg/day) & 1091 & 1085 & 1136 & 1170 & $1023 i 423$ \\
\hline Iron (mg/day) & 12 & 13 & 14 & 14 & $12 \pm 4$ \\
\hline Thiamin (mg/day) & 1.2 & 1.2 & 1.3 & 1.4 & \pm 0.4 \\
\hline Riboflavin (mg/day) & 1.8 & 19 & 2.0 & 2.0 & \pm 0.6 \\
\hline Vitamin $\mathrm{C}(\mathrm{mg} /$ day $)$ & 113 & 125 & 132 & 141 & \pm 55 \\
\hline
\end{tabular}

\section{Data at the household level}

Table 3.2 gives data on intake of energy and some nutrients, according to household size. Because of the small number of households of seven or more persons these households were excluded from this analysis. The size of the remaining 2190 households varied from one to six persons. In order to adjust for consumption differences due to differences in age, sex, etc., individual nutrient intake was related to energy (energy \% or per MJ) before the average intake per household was calculated and analysed with the non-parametric test of Kruskal and Wallis (10).

In general, differences among the various household sizes regarding energy derived from fat, protein and alcohol were rather small. In the one- or two-person households the highest contribution of these nutrients was observed. In contrast, carbohydrates, especially mono- and disaccharides, were more important energy sources in households of three or more persons. Relative to those living alone the diet of subjects living in households of two or more persons showed a lower density of dietary fibre and micronutrients. For iron, thiamin and vitamin $\mathrm{C}$ a similar observation was made when comparing households of two versus more persons. Energy intake was about $0.8-1.0 \mathrm{MJ} /$ day lower for those living solitarily than for members of other households.

\section{Identification of a risk categony}

One of the goals of the DNFCS is to identify risk groups and risk nutrients. As an example, Table 3.3 presents the intake of energy and some nutrients in women aged 22-49, as compared with the Dutch Recommended Dietary Allowances (DRDA) 
Table 3.2. Individual daily intake (mean \pm SD) of energy and selected nutrients according to household size. ${ }^{1}$

\begin{tabular}{|c|c|c|c|c|c|c|c|c|c|c|c|c|}
\hline $\begin{array}{l}\text { Houeshold size } \\
\text { (number of households) }\end{array}$ & $\begin{array}{l}1 \\
(n=\end{array}$ & 474) & 2 & 697) & $\begin{array}{l}3 \\
(n=\end{array}$ & 366) & 4 & 468) & $\begin{array}{l}5 \\
(n=\end{array}$ & 154) & $\begin{array}{l}6 \\
(n=3\end{array}$ & 31) \\
\hline Age (years) & 48.1 & \pm 17.9 & 47.9 & \pm 17.6 & 31.7 & \pm 11.2 & 25.1 & \pm 6.7 & 22.4 & \pm 5.8 & 21.9 & \pm 5.6 \\
\hline $\begin{array}{l}\text { \%of energy derived from } \\
\text { Fat (total) } \\
\text { Saturated fatty acids } \\
\text { Protein } \\
\text { Carbohydrates (total) } \\
\text { Mono- and disaccharides } \\
\text { Alcohol }\end{array}$ & $\begin{array}{l}39.6 \\
17.1 \\
14.8 \\
42.0 \\
21.2 \\
3.6\end{array}$ & $\begin{array}{l} \pm 8.2 \mathrm{cl} \\
\pm 4.2^{\mathrm{de}} \\
\pm 4.3^{\mathrm{cde}} \\
\pm 8.2^{\mathrm{cdef}} \\
\pm 7.4^{\mathrm{cdef}} \\
\pm 5.3^{\mathrm{b}}\end{array}$ & $\begin{array}{l}41.0 \\
17.1 \\
14.0 \\
40.9 \\
20.2 \\
4.1\end{array}$ & $\begin{array}{l} \pm 6.4^{\mathrm{de}} \\
\pm 3.3^{\mathrm{cde}} \\
\pm 2.9^{\mathrm{de}} \\
\pm 6.6^{\mathrm{cdef}} \\
\pm 5.8^{\mathrm{cdef}} \\
\pm 4.6^{\mathrm{acde}}\end{array}$ & $\begin{array}{l}40.1 \\
16.4 \\
13.4 \\
43.9 \\
22.6 \\
2.5\end{array}$ & $\begin{array}{l} \pm 5.6 \\
\pm 2.7^{\mathrm{b}} \\
\pm 2.1^{\mathrm{ade}} \\
\pm 6.0^{\mathrm{abe}} \\
\pm 5.6^{\mathrm{abe}} \\
\pm 3.1^{\mathrm{b}}\end{array}$ & $\begin{array}{l}39.7 \\
16.1 \\
12.9 \\
45.1 \\
23.7 \\
2.3\end{array}$ & $\begin{array}{l} \pm 5.3^{\mathrm{b}} \\
\pm 2.4^{\mathrm{ab}} \\
\pm 2.3^{\mathrm{abc}} \\
\pm 5.2^{\mathrm{ab}} \\
\pm 5.0^{\mathrm{ab}} \\
\pm 2.5^{\mathrm{b}}\end{array}$ & $\begin{array}{l}38.9 \\
16.0 \\
12.7 \\
46.6 \\
24.3 \\
1.9\end{array}$ & $\begin{array}{l} \pm 5.5^{\mathrm{b}} \\
\pm 2.4^{\mathrm{ab}} \\
\pm 2.0^{\mathrm{abc}} \\
\pm 5.6^{\mathrm{abc}} \\
\pm 5.2^{\mathrm{ab}} \\
\pm 2.3^{\mathrm{b}}\end{array}$ & $\begin{array}{l}39.0 \\
16.1 \\
13.0 \\
46.6 \\
24.3 \\
1.4\end{array}$ & $\begin{array}{l} \pm 4.9 \\
\pm 2.1 \\
\pm 2.2 \\
\pm 5.5^{\mathrm{ab}} \\
\pm 4.8^{\mathrm{ab}} \\
\pm 2.1\end{array}$ \\
\hline Energy (MJ) & 8.8 & $\pm 2.4^{b c d}$ & 9.8 & $\pm 2.4^{\mathrm{a}}$ & 9.6 & $\pm 1.9^{\mathrm{a}}$ & 9.6 & $\pm 1.9^{\mathrm{a}}$ & 9.5 & \pm 2.0 & 9.3 & \pm 2.0 \\
\hline $\begin{array}{l}\text { Intake per MJ } \\
\text { Dietary fibre }(\mathrm{g}) \\
\text { Calcium }(\mathrm{mg}) \\
\text { Iron }(\mathrm{mg}) \\
\text { Thiamin }(\mu \mathrm{g}) \\
\text { Riboflavin }(\mu \mathrm{g}) \\
\text { Vitamin } \mathrm{C}(\mathrm{mg})\end{array}$ & $\begin{array}{l}2.8 \\
132 \\
1.5 \\
125 \\
196 \\
11\end{array}$ & $\begin{array}{l} \pm 1.0^{\mathrm{bcde}} \\
\pm 53 \mathrm{bcde} \\
\pm 0.6^{\mathrm{bcdef}} \\
\pm 47 \mathrm{de} \\
\pm 96^{\mathrm{bcde}} \\
\pm 9 \mathrm{bcde}\end{array}$ & $\begin{array}{l}2.5 \\
111 \\
1.3 \\
119 \\
172 \\
9\end{array}$ & $\begin{array}{l} \pm 0.8^{\mathrm{a}} \\
\pm 40^{\mathrm{a}} \\
\pm 0.4^{\mathrm{acde}} \\
\pm 38^{\mathrm{de}} \\
\pm 55^{\mathrm{a}} \\
\pm 6^{\mathrm{ad}}\end{array}$ & $\begin{array}{l}2.4 \\
110 \\
1.2 \\
116 \\
171 \\
8\end{array}$ & $\begin{array}{l} \pm 0.7^{\mathrm{a}} \\
\pm 32^{\mathrm{a}} \\
\pm 0.3^{\mathrm{ab}} \\
\pm 33^{\mathrm{d}} \\
\pm 42^{\mathrm{a}} \\
\pm 6^{\mathrm{a}}\end{array}$ & $\begin{array}{l}2.4 \\
108 \\
1.2 \\
108 \\
167 \\
7\end{array}$ & $\begin{array}{l} \pm 0.6^{\mathrm{a}} \\
\pm 31^{\mathrm{a}} \\
\pm 0.3^{\mathrm{ab}} \\
\pm 31^{\mathrm{abc}} \\
\pm 39^{\mathrm{a}} \\
\pm 5^{\mathrm{ab}}\end{array}$ & $\begin{array}{l}2.4 \\
109 \\
1.2 \\
106 \\
167 \\
8\end{array}$ & $\begin{array}{l} \pm 0.6^{\mathrm{a}} \\
\pm 28^{\mathrm{a}} \\
\pm 0.2^{\mathrm{ab}} \\
\pm 28^{\mathrm{ab}} \\
\pm 36^{\mathrm{a}} \\
\pm 5^{\mathrm{a}}\end{array}$ & $\begin{array}{l}2.5 \\
116 \\
1.2 \\
106 \\
178 \\
8\end{array}$ & $\begin{array}{l} \pm 0.6 \\
\pm 28 \\
\pm 0.3^{\mathrm{a}} \\
\pm 27 \\
\pm 42 \\
\pm 3\end{array}$ \\
\hline
\end{tabular}

${ }_{1}$ Significant differences among household sizes $(P<0.05)$ are designated with superscripts as follows: a $=$ different from 1-person households, $\mathrm{b}=$ different from 2-person households, $\mathrm{c}=$ different from 3-person housegholds, $\mathrm{d}=$ different from 4-person households, $\mathrm{e}=$ different from 5-person households. $\mathrm{f}=$ different from 6-person households. 
Table 3.3. Average daily intake of energy and selected nutrients among 1341 women aged 22-49 (pregnant women excluded) compared with Dutch Recommended Dietary Allowances (DRDAs).

\begin{tabular}{|c|c|c|}
\hline & Mean $\pm S D$ & DRDA \\
\hline Energy (MJ) & $8.8 \pm 2.4$ & 8.7 \\
\hline \multicolumn{3}{|l|}{$\%$ of energy derived from } \\
\hline fat (total) & $41.1 \pm 7.3$ & $30-35$ \\
\hline saturated fatty acids & $17.1 \pm 3.5$ & $\leq 10$ \\
\hline protein & $14.0 \pm 3.5$ & $10-15$ \\
\hline carbohydrates (total) & $41.8 \pm 7.6$ & 55 \\
\hline mono- and disaccharides & $20.6 \pm 7.4$ & $15-25$ \\
\hline alcohol & $3.1 \pm 4.9$ & - \\
\hline Dietary fibre (g/MJ) & $2.5 \pm 0.9$ & $\geq 3$ \\
\hline Calcium (mg) & $1001 \pm 400$ & $700-900$ \\
\hline Iron (mg) & $11.5 \pm 3.4$ & 15 \\
\hline Thiamin (mg) & $1.00 \pm 0.34$ & 1.0 \\
\hline Riboflavin (mg) & $1.49 \pm 0.53$ & 1.3 \\
\hline Vitamin C (mg) & $70 \pm 49$ & 70 \\
\hline
\end{tabular}

(11). Pregnant women were excluded from the analyses. Since the intake of iron in women aged 22-49 did not meet the DRDA, this category was identificd as a risk group with regard to iron supply. As in the total population, this group's mean intake of macro-nutrients was not well balanced. The contribution of tat, particularly of saturated fatty acids, was too high, whereas energy supply from carbohydrates and intake of dietary fibre were too low (Table 3.3).

For prevention-oriented educational programmes it is important to identify foods or food groups that are main sources of iron and fat. Women aged 22-49 obtained about $20 \%$ of total iron intake from animal products. Bread and vegetables accounted for about $30 \%$, and non-alcoholic beverages for about $17 \%$. The latter percentage is mainly supplied by coffee and tea (75\%). However, due to presence of polyphenols coffee and tea cannot be considered a good source of iron (12). The predominant sources of fat were fats and oils (29\%), meat and meat products $(20 \%)$ and milk (products) and cheese (20\%). Products mainly eaten between the meals, such as nuts or savoury snacks and pastries or biscuits, appeared to contribute substantially ( $8 \%$ ) to total fat intake.

\section{Discussion}

A response rate of $81 \%$ (individual level) can be considered satisfactory for studies of this nature. However, recruitment from a panel as well as non-response might have introduced a selection bias. To correct for possible bias due to differences in sociodemographic factors a weighing procedure was developed to restore the 
balance between characteristics of the sample and the actual population structure in the Netherlands. The differences in age and sex distribution appeared to be small. Differences in intake of nutrients and foods observed between the unweighed and weighed sample were negligible. Therefore we decided to use unweighed data only. It is important to realize that institutionalized subjects and private households with a head housekeeper aged 75 or over were not eligible. Other special categories, such as ethnic minorities, are underrepresented due to the criterion regarding the Dutch language.

\section{Data at the national level}

It is generally accepted that trends in availability of foods and selected nutrients are the most useful information provided by FBSs. A great advantage of the DNFCS as a national representative sample of individuals is that, in addition to average availability of foods, data on variation in intake and distribution can be obtained. However, the DNFCS is expensive and will not be repeated annually, but probably once every five years. The annual FBS data are not comparable with the results of the DNFCS because the former estimate availability of foods rather than food consumption. If the results of both studies are valid, the trends over the same period should point to the same direction. For this type of comparison, especially for the interpretation of trends indicated by food availability data in the past, it would be worthwhile to continue the collection of FBSs, at least in the near future.

\section{Data at the household level}

The study design of the DNFCS provides the opportunity to achieve insight into the consumption at the household level. To classify households into groups various characteristics can be used. The observed differences according to household size indicated that the macronutrient composition of the diet of those living in households of four or more persons was in slightly better agreement with the dietary guidelines than those in the smaller households. Conversely, the diet of those living alone was more in accordance with the recommendations for dietary fibre and micronutrients. Other household characteristics, i.e., the household composition with respect to age and number of adults, number and age range of the children, socio-economic level, and educational level of the housewife, are likely to have an impact on food intake and may be used to achieve a better understanding of the complexity of food patterns.

\section{Identification of risk groups}

Two food record days do not give a representative picture of individuals' habitual intake, so that individuals at long-term nutritional risk cannot be identified. However, two record days allow a calculation of day-to-day variations and an 
estimate of the ratio between intrapersonal and interpersonal variation (13). The latter variable makes it possible to calculate more reliable the proportion of the population at nutritional risk. Furthermore, it is possible to identify risk categories based on age, sex etc. Since the DNFCS also includes sociodemographic and some personal characteristics, it offers a wide range of possibilities for identifying risk groups, for instance with respect to socio-economic status. In this paper we have presented only one example of an age-sex group identified as a risk group for low iron intake.

\section{Future perspectives}

It should be stressed that food consumption data do not allow for definite conclusions as to the occurrence of deficiencies within population groups. Investigations into the nutritional health status are needed to confirm the results for groups identified as being at risk for a particular nutrient. Insight into the characteristics of these groups and their food consumption patterns is very inportant for nutrition policies aiming at recommendations to promote health and prevent disease. Food labelling and legislation can be tuned to actual food consumption, and nutrition education programmes can be adapted to the food patterns of the target group.

The perspectives mentioned emphasize that DNFCS data can be expected to meet the goals formulated for the national food consumption surveys. Besides policyoriented information, the data of the DNFCS may be used to support basic and applied research (2). Trend analyses will be possible after the second DNFCS has been completed, which is planned for 1992-93. In December 1988, the owners of the data (the Ministry of Welfare, Public Health and Cultural Affairs and the Ministry of Agriculture, Nature Management and Fisheries) established a committee to stimulate and coordinate the use of the DNFCS data. Tapes containing the DNFCS data are available on request. ${ }^{1}$

\section{References}

1. Voedingsraad. Mogelijkheden tot het opzetten van een voedingspeilingssysteem in Nederland. Voeding 1987:48: 35-43.

2. Löwik MRH, Hermus RJJ. The Dutch nutrition surveillance system. Food Policy 1988:13: 359-365.

3. Anonymous. Wat eet Nederland. Rijswijk: Ministerie van Welzijn. Volksgezondheid en Cultuur en Ministerie van Landbouw en Visserij. 1988.

'The tapes cost NLG 5000. Further information from: Dr. M.R.H. Lowik (Execulive Secretary), Department of Human Nutrition, TNO Nutrition and Food Research, PO Box 360, 3700 AJ Zeist. Netherlands (telefax +31340457224 ). 
4. The Dutch National Food Consumption Survey (DNFCS) is financially supported by the Ministries of Welfare, Public Health \& Cultural Affairs and Agriculture, Nature Management \& Fisheries of the Netherlands.

5. AGB Attwood. Mgr. Schaepmanlaan 55, 5103 BB Dongen, Netherland.

6. Hautvast JGAJ. Ontwikkeling van een systeem om gegevens van voedingsenquetes met behulp van een computer te verwerken. Voeding 1975;36: 356-360.

7. NEVO-tabel. Nederlands Voedingsstoffenbestand 1986-1987. Voorlichtingsbureau voor de Voeding. The Hague, 1987.

8. CBS. Bevolkingsprognose voor Nederland. 1988-2050. Statistisch Bulletin 1988:44:5.

9. Godeschalk FE. Consumptie van voedingsmiddelen in Nederland in 1986 en 1987. Periodical report No 64-86/87. The Hague: Agriculture Economics Research Institute (LEI), 1989.

10. Siegel S. Nonparametric statistics. NY: McCrawn Hill. New York, 1956.

11. Voedingsraad. Nederlandse Voedingsnormen 1989. The Hague: Voorlichtingsbureau voor de Voeding, 1989.

12. Monsen R. Iron nutrition and absorption: Dietary factors which impact iron availability. J Am Diet Assoc 1988:88: 786-790.

13. Bingham SA, Nelson M, Paul AA. Haraldsdöttir J, Løken EB and Van Staveren WA. Methods for data collection at an individual level. In: Cameron ME and Van Staveren WA (eds.). Manual on methodology for food consumption studies. New York: Oxford University Press, 1988: 53-106. 


\title{
Comparison of dietary intake data with guidelines: some potential pitfalls \\ (Dutch Nutrition Surveillance System)
}

\author{
K.F.A.M. Hulshof, M.R.H. Löwik, C. Kistemaker, R.J.J. Hermus, F. ten Hoor, \\ Th. Ockhuizen
}

\begin{abstract}
In evaluating dietary data with reference to guidelines for a healthy diet, some potential pitfalls (i.e., method of food consumption assessment and calculation to include or exclude energy derived from alcohol) were investigated. The percentage of energy intake (en\%) derived from total fat, saturated fatty acids (SFA), monoand disaccharides (MD) and intake of cholesterol and dietary fibre per megajoule were calculated using 2-day records obtained in the Dutch National Food Consumption Survey of 1987-1988. Subjects (aged 4-85, $n=5595$ ) were classified into age-sex groups. Mean values and intake distributions were calculated with and without adjustment for within-person variation. Except for the intake of cholesterol and MD, mean intake levels were not in accord with guidelines. About $20 \%$ of the women and $23 \%$ of the men met the goal for fat intake, $20 \%$ of the men and $27 \%$ of the women for dietary fibre, and about 60 and $70 \%$ for MD and cholesterol. Only $3 \%$ of subjects had a SFA intake $\leq 10 \mathrm{en} \%$, whereas $<1 \%$ had a diet in accord with all criteria studied. After adjustment for within-person variation, percentages meeting the guidelines were generally lower for fat, SFA and dietary fibre, and slightly higher for cholesterol and MD. Among the elderly, unadjusted results were more in agreement with the prevalence estimates based on habitual dietary intake data than with adjusted ones. Fat intake (en\%) was inversely related with intake of added MD and alcohol. Our data indicate that guidelines should state explicitly whether energy-related recommendations include energy derived from alcohol, and that the prevalence of a high fat intake is more affected by the calculation method than by food consumption assessment.
\end{abstract}




\section{Introduction}

Nutritional assessment is of increasing importance since evidence is accumulating that various dietary habits are related to health $(1,2)$. In the past decade, many expert groups have issued dietary goals or recommendations aimed at maintaining good health or preventing specific chronic diseases (usually cardiovascular disease and/or cancer). These recommendations can have an individual-based approach, aimed at identifying and treating individuals at high risk, or a public health approach, focusing on the population as a whole (2). Most national recommendations apply to a general population and differ little among affluent countries (3).

Recommendations may be issued in either qualitative terms (guidelines) or quantitative terms (goals). Although quantitative goals have certain drawbacks $(4,5)$ for dietary evaluation purposes, this type of information is most popular. One of the drawbacks is that several interrelated dietary aspects are not formulated in quantitative terms. so that improving one aspect may negatively affect another one. Furthermore. no priorities or weighting factors are provided, which hampers a proper evaluation. Since a positive effect on public health is likely to be accomplished with a reduction of saturated fat (SFA) intake $(1,6)$, in the Nel.herlands priority is given to reduction of fat consumption. The quantified goals as to fat, cholesterol, etc. are mostly related to energy, whereby the intake of alcohol may be a confounder in risk assessment, especially since it is still controversial whether all energy from alcohol is efficiently used by the human body $(7,8)$. The Dutch guidelines for a healthy diet $(9,10)$ do not state whether calculations should include or exclude energy from alcohol, and it is unknown to what extent this affects the results of nutritional assessment.

Other potential pitfalls in the evaluation of dietary intake data are related to food consumption methodology. For instance, prevalence values of high fat intake levels will depend on the number of days being studied in a particular survey. According to the World Health Organization (WHO), the mean or median value of a distribution should be the starting point for risk assessment (2). When the mean valuc's are in line with the guidelines it is implicitly assumed that the distributions underlying thesc values do not reflect health risks for a substantial part of the population. This may be incorrect when the intake range is relatively large. In that asc the entire distribution is of interest, especially when certain low or high intake levels correspond with disproportional health risks. Within-person variance can distort estimates of percentiles above or below particular cut-off values by increasing the total variance of the distribution (1,11-13). Therefore, in calculating proportions meeting the guidelines, data based on habitual consumption may provide more stable estimates and are more appropriate when the risks are applied to chronic diseases rather than data that refer to intake over the short term. Distributions based on dietary information on $: 2$ days can theoretically be transformed (based on withinperson variance) to habitual intake levels. 
In the literature most attention is given to the distortion by food consumption methodology. However, it is not known whether this distortion is the most important confounder in dietary risk assessment. To investigate the extent to which nutritional assessment is influenced by different calculation methods (including or excluding energy from alcohol) and food consumption methodology (short- vs. long-term evaluation), we used data of a nationwide food consumption survey in the Netherlands.

\section{Subjects and methods}

In 1987-1988, the first Dutch National Food Consumption Survey (DNFCS) was conducted within the framework of the Dutch Nutrition Surveillance System $(14,15)$. Data were obtained from a probability sample of non-institutionalized Dutch aged 1-85 $(n=5898$; response $81 \%)$. Since the Dutch guidelines for a healthy diet apply to those aged 4 years or over, children under 4 were cxcluded, leaving 5595 subjects for analysis. Methods regarding sampling procedure and dietary data collection have been described in detail elsewhere (15). Information on food intake was collected with a 2-day record. In each household the person principally responsible for domestic affairs (main housekeeper) was the most important informant and was visited on two occasions by a specially trained dietitian. During the first visit the household diary was explained. In this diary all the food supplied by the main housekeeper to the household members as well as information on cooking methods. recipes and ingredients were recorded. The number of persons (including visitors) attending the different meals and the amounts of foods used by them, as well as amounts of leftovers and foods given to pets, were noted. Household members (except children under 13) recorded food eaten outdoors in separate diaries. During the second visit the interviewers checked the diaries. Common household measures and food regularly used (i.e., slices of bread, amount of fat spread on bread, amount of sugar added to tea and coffee) were weighed. All this information was used for the conversion of household data into intake figures on an individual level.

In addition to food consumption data, information on the respondent's body weight and body height (both self-reported figures), use of nutritional supplements, special dietary practices, etc., were collected by structured questionnaires included in the personal diary. Since respondents were recruited from an existing panel of the Marketing Research Institute AGB-Attwood, which carried out the field work, data on demographic and socio-economic characteristics were already available.

Food consumption data were coded and converted into figures for intake of energy and nutrients with an extended computerized version of the 1986/1987 Dutch food consumption table (16). Nutritional supplements were not included in the calculation of nutrient intake. Foodstuffs were classified into 23 major food groups on the basis of similarity in nutrient composition and/or origin. 
Table 4.1. Desirable dietary changes in terms of nutrients, according to the Dutch guidelines for a healthy diet.

- As a general rule, it is recommended to eat a variety of foods and to maintain or achieve optimal body weight. For adults body mass index (weight divided by height squared $\left(\mathrm{kg} / \mathrm{m}^{2}\right)$, should be $20-25$.

- Reduce fat intake from an average of 40 to $30-35 \%$ of daily energy intake (en\%), by limiting the amount of saturated fatty acids (SFA) consumed. The consumption of polyunsaturated fatty acids (PUFA) should increase somewhat such that the ratio of PUFA to SFA (P/S ratio) is between 1:2 and 1:1. Since 1991 the recommended contribution of SFA is $\leq 10 \mathrm{en} \%$ and no special guidelines for the $\mathrm{P} / \mathrm{S}$ ratio are given.

- Restrict consumption of cholesterol; individual intake should be such that the current average level of $33 \mathrm{mg} / \mathrm{MJ}$ is not exceeded.

- Increase the intake of complex carbohydrates, limit the frequency of sugar consumption and avoid excessive consumption of sugars (both mono- and disaccharides). Total carbohydrate intake should be raised from its current level of 45 to 55 en\% through an increased consumption of complex carbohydrates. An acceptable intake level of monoand disaccharides is $15-25$ en $\%$.

- Increase the average relative intake of dietary libre from approximatcly 2.4 to $3.0 \mathrm{~g} / \mathrm{MJ}$.

- When alcohol is used it should be consumed only in moderation.

- Restrict the use of salt. The individual intake should not exceed the current daily average of $9 \mathrm{~g}$.

Individual average intakes over 2 days were calculated. Data were first converted to the average of 2 days for each variable for each subject. Thereafter, statistics (e.g., mean value and distribution) for the various age-sex groups were calculated using BMDP statistical programs (17).

Table 4.1 presents the goals in terms of intake levels of nutrients as given in the Dutch guidelines. Intake of the following nutrients was compared with guidelines: fat (en\%), SFA (en\%), mono- and disaccharides (MD; en\%), cholesterol (mg/MJ) and dietary fibre $(\mathrm{g} / \mathrm{MJ})$. Dietary fibre intake had a closer relation with consumption of polysaccharides (overall $r=0.39$, range among population groups 0.22 to 0.52 ) than with intake of MD ( $r=-0.05$, range -0.21 to 0.12$)$. The correlation between MD and total carbohydrates was much higher than between polysaccharides and total carbohydrates $(r=0.83$, range 0.63 to 0.89 and $r=0.36$, range 0.17 to 0.60 , respectively). These interrelationships indicate that these aspects of the diet cannot be separated and that these aspects provide information about the other aspects as well. Since quantitative goals were formulated for total carbohydrates, MD and dietary fibre, we decided to study the latter two nutrients to obtain insight into several components of carbohydrate intake. Although the intake of total fat and SFA is interrelated ( $r=0.80$, range 0.74 to 0.87 ), both were studied since fat intake is the most important risk factor in the Dutch diet. Because food consumption data do not allow for a valid estimate of sodium intake (18), salt consumption was not studied.

With individual dietary data on 2 consecutive days, we were able to examine the effect of within-person variation on the selected criteria. This was done by comparing the shape of the distribution curves, and the prevalence of intakes above or below 
cut-off values before and after distributions were 'adjusted' for within-person variance. Between-person and within-person variation components of dietary intake figures were assessed by analysis of variance, using GENSTAT (19). The overall variability in a distribution of dietary intake can be described as follows:

$$
S_{\mathrm{obs}}=S_{\mathrm{b}}+S_{\mathrm{w}} / k
$$

where $S_{\text {obs }}=$ total variance of data (square of observed SD),

$S_{\mathrm{b}}=$ between-person variance,

$S_{\mathrm{w}}=$ within-person variance,

and $k=$ number of replicated measures obtained from each individual.

The approach recommended by the US National Academy of Sciences Subcommittee on Criteria for Dietary Evaluation (20) was chosen to adjust the distributions in order to remove within-person variation. Each individual value was adjusted using the following formula:

$$
y=\left(x_{i}-\bar{x}\right)\left(S_{\mathrm{b}} S_{\text {obs }}\right)+\bar{x}
$$

where $y=$ the adjusted value.

$\bar{x}=$ the average or group mean.

and $x_{i}=$ the value for the $i$-th respondent.

Since distributions for cholesterol intake per megajoule and dietary fibre intake per megajoule were skewed, individual values were transformed logarithmically before entering into the calculations. After adjustment, the distribution was converted back to the original units by computing the exponential of the values (20).

Comparisons of the mean values for dietary intake among groups with a relatively low and a high adjusted fat intake (en\%) were made by analysis of variance. Log transformations $(\ln +1)$ were performed on the intake of alcohol $(\mathrm{en} \%)$ and nutrients expressed per megajoule (calcium, iron, B vitamins, vitamin C, cholesterol and dietary fibre) before analysis because the distributions were skewed. For these nutrients geometric means are presented since this fits in with the way the analyses were carried out. The intake of food groups was analysed with non-parametric methods (Kruskal-Wallis test [21]). Differences in discrete variables (e.g., sociodemographic factors, smoking, special dietary habits, obesity (based on body mass index (BMI) according to Garrow [22]) were examined with $x^{2}$ tests. Data analysis was performed with the BMDP statistical computer package (17). A $P$ value $<0.05$ was considered significant.

\section{Results}

Table 4.2 shows characteristics of the population according to gender and age. Eight percent of males and $15 \%$ of females followed a dietary regimen. Among subjects with a non-prescribed diet about half of men and $38 \%$ of women had a vegetarian or 
Table 4.2. Characieristics of the population aged 4 years and over.

\begin{tabular}{lccc}
\hline & $\begin{array}{c}\text { All } \\
(n=5595)\end{array}$ & $\begin{array}{l}\text { Men } \\
(n=2625)\end{array}$ & $\begin{array}{l}\text { Women } \\
(n=2970)\end{array}$ \\
Age group (years), \% & & & \\
$4-6$ & 4.6 & 4.9 & 4.3 \\
$7-9$ & 4.5 & 4.6 & 4.5 \\
$10-12$ & 5.1 & 5.6 & 4.6 \\
$13-15$ & 5.5 & 5.9 & 5.0 \\
$16-18$ & 5.5 & 5.4 & 5.6 \\
$19-21$ & 3.6 & 3.4 & 3.8 \\
$22-49$ & 46.0 & 47.9 & 45.2 \\
$50-64$ & 15.5 & 14.7 & 9.3 \\
$\geq 65$ & 8.8 & 8.6 & 1.8 \\
Pregnant women & 0.9 & - & \\
Dietary regimen, \% & & & 8.1 \\
Prescribed & 6.7 & 5.1 & 7.2 \\
Not prescribed & 5.4 & 3.2 & 40.9 \\
Alcohol users $(\%) '$ & 51.3 & 63.3 & 35.3 \\
Smokers $(\%){ }^{\prime}$ & 39.9 & 45.2 & \\
\hline
\end{tabular}

' Only those aged 16 and over.

macrobiotic diet ( 1.7 and $2.7 \%$ of the total population, respectively); diets used on subjects' own initiative were mainly slimming diets. In the group 16 years or older, $63 \%$ of the men and $41 \%$ of the women had used alcohol during the 2 -day record period. Of the men aged 19 and over, $34 \%$ were overweight and $4 \%$ were obese; among women, these percentages were 23 and 7 , respectively.

Table 4.3. Mean daily intake of energy and selected nutrients according to gender in comparison with dictary goals.

\begin{tabular}{lccc}
\hline & $\begin{array}{l}\text { Men } \\
(n=2625)\end{array}$ & $\begin{array}{l}\text { Women } \\
(n=2970)\end{array}$ & Goal \\
Energy (MJ) & 11.2 & 8.6 & -1 \\
Total fat (en\%) & 40.0 & 40.5 & $30-35$ \\
Saturated fatty acids (en\%) & 16.3 & 16.9 & $\leq 10$ \\
Cholesterol (mg/MJ) & 30 & 32 & $\leq 33$ \\
Mono- and disaccharides (en\%) & 21.6 & 22.3 & $15-25$ \\
Total carbohydrates (en\%) & 43.3 & 43.5 & $50-55$ \\
Dietary fibre & 2.4 & 2.6 & $\geq 3$ \\
Alcohol (en\%) & $3.8(4.8)^{3}$ & $2.1(2.6)$ & - \\
\hline
\end{tabular}

1 Requirement depends on age. gender and physical activity.

${ }^{2} \mathrm{En} \% \%$ of total energy intake.

"In parenthesis: those aged 16 and over. 
Table 4.3 presents the mean daily intake of energy and selected nutrients according to gender. Except for intakes of cholesterol and MD, mean intake levels were not in accord with the guidelines for a healthy diet.

Mean values differed somewhat among age groups. Ranges of the mean values were 38.3-41.5 for fat (en\%), 15.1-17.6 for SFA (en\%), 19.3-28.7 for MD (en\%), and $<0.1-5.4$ for alcohol (en\%). Intake of cholesterol varied from 25 to $37 \mathrm{mg} / \mathrm{MJ}$, and dietary fibre intake from 2.3 to $2.9 \mathrm{~g} / \mathrm{MJ}$. Among adult population groups the average intake of fat, SFA, alcohol, cholesterol and dietary fibre (especially among women) was higher than among children. Among children under 16 mean intake of MD exceeded 25 en\%. When naturally occurring MD (e.g., lactose in milk and fructose, glucose, maltose in fruit and vegetables) and added MD (e.g., white or brown sucrose, short-chain sugars produced through refinement of carbohydrates) were considered separately, the latter accounted for $14-18 \%$ of energy intake among children and adolescents and $10-11 \%$ among adults.

Proportions of the groups meeting the various goals are given in Table 4.4. About $20 \%$ of the women and $23 \%$ of the men met the goal for fat intake $(<35$ en\%), $20 \%$ of the men and $27 \%$ of the women for dietary fibre and about 60 and $70 \%$ for MD and cholesterol. About 3\% of the subjects met the goal for SFA intake $(\leqslant 10 \mathrm{en} \%)$. In the younger age groups more subjects met the guidelines for fat and cholesterol, whereas for MD and dietary fibre higher proportions were found for adolescents and adults. Lower percentages were observed when dietary goals were combined. About $17 \%$ of the subjects met both the fat and cholesterol goals, $8 \%$ met the criteria for both fat and fibre, and $8 \%$ met both fat and MD goals. Only 2.7\% complied with the combined guideline for fat and SFA, whereas $<1 \%$ had diets in accord with all criteria studied (Table 4.4).

After adjustment for within-person variation percentages meeting the goal were found to be generally lower when the unadjusted percentages were $<50$, and higher (cholesterol) when they were $>50$ (Table 4.4). The original and adjusted distributions for fat, SFA and cholesterol for men aged 22-49 are given in Figs. 4.1-4.3. Similar results were found for women aged 22-49 (results not shown). Unadjusted distributions are flatter and wider than are adjusted ones. A higher percentage of men than women met the guidelines for fat, MD and cholesterol (both adjusted and unadjusted).

Table 4.5 shows the intake of energy and nutrients among adults aged 22-49, grouped by fat intake. After adjustment, about $15 \%$ of the men and $12 \%$ of the women had diets with $<35 \mathrm{en} \%$; in $52 \%$ of the men and $60 \%$ of the women the proportion of energy derived from fat was $\geq 40 \%$. A low fat intake (en\%) was associated with a lower intake of energy (differences in mean energy intake between low- and high-fat groups being $13 \%$ for men and $29 \%$ for women) and cholesterol $(\mathrm{mg} / \mathrm{MJ})$, and with a lower proportion of energy derived from the various groups of fatty acids. The contribution of protein (only in women), carbohydrates (especially $\mathrm{MD}$ ) and alcohol to daily energy intake was higher in the groups with a relatively low 
Table: 4.4. Proportion of subjects (\%) with an intake mecting the goals of the dietary guidelines, unadjusted (unadj) and after adjustment (adj) for within-person variation, according to age and gender.

\begin{tabular}{|c|c|c|c|c|c|c|c|c|c|c|c|c|}
\hline \multirow[t]{2}{*}{$\begin{array}{l}\text { Age group } \\
\text { (yrs) }\end{array}$} & \multicolumn{2}{|c|}{$\begin{array}{l}\text { Total fat } \\
<35 \text { en } \%\end{array}$} & \multicolumn{2}{|c|}{$\begin{array}{l}\text { Saturated fat } \\
\leq 10 \text { en } \%\end{array}$} & \multicolumn{2}{|c|}{$\begin{array}{l}\text { Mono/disaccharides } \\
<25 \mathrm{en} \%\end{array}$} & \multicolumn{2}{|c|}{$\begin{array}{l}\text { Cholesterol } \\
\leq 33 \mathrm{mg} / \mathrm{MJ}\end{array}$} & \multicolumn{2}{|c|}{$\begin{array}{l}\text { Dictary fibre } \\
\geq 3 \mathrm{~g} / \mathrm{MJ}\end{array}$} & \multicolumn{2}{|c|}{$\begin{array}{l}\text { All five } \\
\text { goals }\end{array}$} \\
\hline & unadj & adj & unidj j & adj & unadj & adj & unadj & adj & unadj & adj & unadj & adj \\
\hline \multicolumn{13}{|l|}{ Men } \\
\hline $4-6$ & 43.0 & 40.6 & 4.7 & 2.3 & 19.5 & 15.6 & 78.9 & 96.9 & 14.8 & 10.2 & 0 & 0 \\
\hline $7-9$ & 30.8 & 21.7 & 4.2 & 0 & 34.2 & 31.7 & 86.7 & 96.7 & 15.8 & 10.0 & 0 & 0 \\
\hline $10-12$ & 27.7 & 25.0 & 3.4 & 0 & 39.9 & 39.2 & 77.7 & 93.9 & 18.9 & 8.8 & 0 & 0 \\
\hline $13-15$ & 19.9 & 13.5 & 2.6 & 0 & 46.8 & 45.5 & 81.4 & 94.9 & 11.5 & 3.8 & 0 & 0 \\
\hline $16-18$ & 26.6 & 19.9 & 3.5 & 1.3 & 60.1 & 57.0 & 75.5 & 83.9 & 10.4 & 7.0 & 0 & 0 \\
\hline $19-21$ & 22.7 & 10.2 & 1.1 & 0 & 69.3 & 71.6 & 79.5 & $?^{2}$ & 27.2 & 21.6 & 0 & 0 \\
\hline $22-49$ & 22.0 & 14.9 & 3.0 & 0.6 & 82.0 & 84.6 & 65.3 & 78.1 & 19.3 & 13.7 & 0.2 & $<0.1$ \\
\hline $50--64$ & 15.8 & 10.6 & 2.1 & 0.3 & 82.1 & 84.7 & 56.2 & 60.1 & 25.9 & 21.0 & 0.3 & 0 \\
\hline$\geq 65$ & 19.5 & 13.3 & 1.8 & 0.4 & 77.4 & 79.2 & 58.4 & 60.1 & 26.5 & 26.5 & 1.3 & 0.4 \\
\hline all & 22.7 & 16.4 & 2.9 & 0.6 & 70.3 & 71.8 & 67.7 & $78.9^{3}$ & 19.8 & 14.1 & 0.3 & 0.2 \\
\hline \multicolumn{13}{|l|}{ Women } \\
\hline $4-6$ & 41.4 & 55.5 & 5.5 & 2.3 & 21.1 & 18.8 & 77.3 & 91.4 & 13.3 & 3.1 & 0 & 0 \\
\hline $7-9$ & 36.1 & 27.8 & 7.5 & 0.8 & 25.6 & 8.3 & 82.7 & 100 & 17.3 & 9.7 & 0 & 0 \\
\hline $10-12$ & 15.9 & 2.2 & 0.7 & 0 & 42.0 & 39.9 & 79.7 & 95.6 & 11.5 & 5.1 & 0 & 0 \\
\hline $13-15$ & 25.5 & 19.5 & 2.7 & 0 & 45.6 & 45.6 & 77.2 & 90.6 & 19.5 & 12.8 & 0 & 0 \\
\hline $16-18$ & 22.2 & 14.5 & 3.0 & 0 & 53.0 & 54.2 & 69.3 & 91.6 & 20.5 & 16.3 & 0 & 0 \\
\hline $19-21$ & 20.4 & 13.3 & 5.3 & 2.7 & 56.6 & 59.3 & 62.8 & 73.5 & 25.7 & 2.3 .0 & 2.6 & 1.8 \\
\hline $22-49$ & 17.4 & 11.5 & 2,1 & 0.5 & 76.7 & 79.5 & 56.9 & 60.9 & 25.3 & 19.7 & 0.2 & $<0.1$ \\
\hline $50-64$ & 17.1 & 12.0 & 2.7 & 1.0 & 76.2 & 82.2 & 46.1 & 44.0 & 38.6 & 35.3 & 0.3 & 0.2 \\
\hline$\geq 65$ & 22.2 & 17.3 & 2.6 & 1.5 & 74.4 & 75.9 & 42.9 & 39.8 & 39.8 & 35.3 & 1.3 & 0.2 \\
\hline all & 20.4 & 15.0 & 2.8 & 0.8 & 66.3 & 67.9 & 58.8 & 64.6 & 26.7 & 21.5 & 0.3 & 0.2 \\
\hline
\end{tabular}

IEn\% \% of total tnergy intake.

${ }^{2}$ Cannot be calculated because the between-person variation was estimated to be zero.

"Men aged 19-21 excluded. 


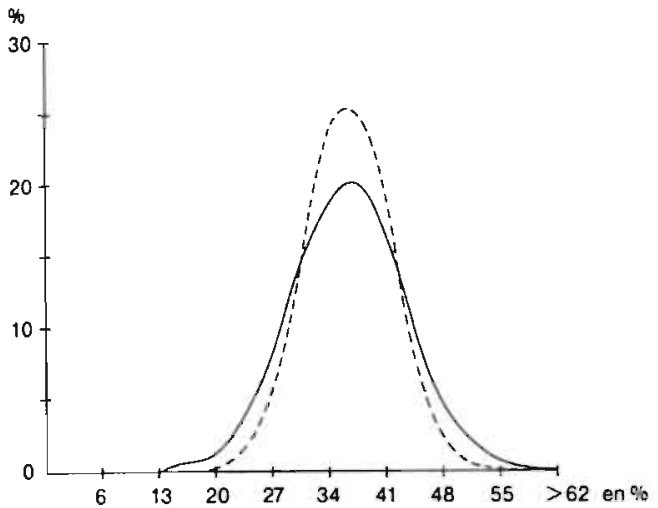

Fig. 4.1. Total fat intake for men aged $22-49$.

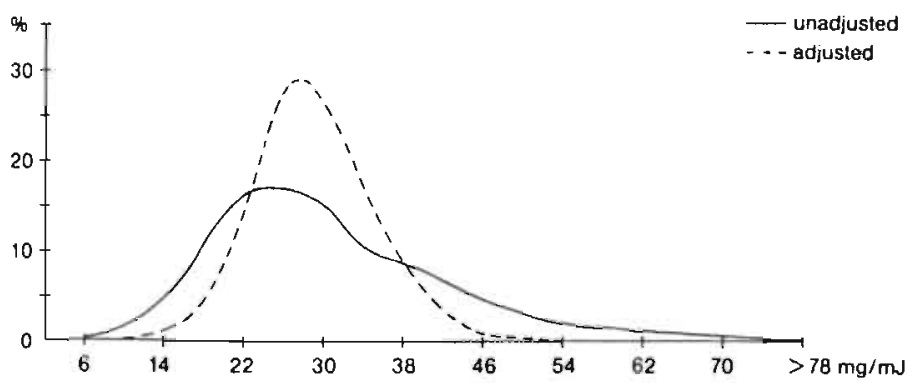

Fig. 4.3. Dietary cholesterol intake for men aged 22-49.

fat intake. In women the nutrient density of the low-fat group was significantly higher (in men only for riboflavin/MJ).

Table 4.6 presents consumption of food groups according to fat intake. Men and women with a relatively low fat intake had the lowest consumption of potatoes, cheese, meat and poultry, edible fats, pastries and biscuits, and savoury snacks, but the average consumption of cereals and alcohulic beverages was highest. Among men, $19 \%$ of the subjects with a low fat intake and $38 \%$ of those with a high fat intake did not use alcoholic beverages during the 2 record days, whereas 41 and $13 \%$, respectively, averaged four or more glasses/day (each containing about $10 \mathrm{~g}$ 
Table 4.5. Mean daily intake of energy and nutrients among men and women, aged 22-49. according to adjusted fat intake $(<35$ and $\geq 40 \%$ of total fat intake, en\%).

\begin{tabular}{|c|c|c|c|c|c|c|c|c|}
\hline \multirow[t]{2}{*}{ Nutrient } & \multicolumn{4}{|c|}{ Men } & \multicolumn{4}{|c|}{ Women } \\
\hline & $\begin{array}{l}<35 \mathrm{en} \% \\
(n=183)\end{array}$ & $\begin{array}{l}\geq 40 \text { en\% } \\
(n=640)\end{array}$ & $\begin{array}{l}\text { pooled } \\
\text { SD }\end{array}$ & $\begin{array}{l}{\text { sign. }{ }^{1}}(n=154)\end{array}$ & $\begin{array}{l}<35 \mathrm{en} \% \\
(n=807)\end{array}$ & $\begin{array}{l}\geq 40 \mathrm{en} \% \\
\mathrm{SD}\end{array}$ & pooled & $\operatorname{sign}$. \\
\hline Energy (MJ) & 10.9 & 12.3 & 2.9 & 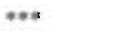 & 7.2 & 9.3 & 2.5 & $* * *$ \\
\hline \multicolumn{9}{|l|}{ Energy $(\%)$ from } \\
\hline Protein & 12.9 & 12.9 & 2.9 & & 16. 1 & 13.5 & 3.6 & $* * *$ \\
\hline Fat & 32.4 & 43.8 & 5.6 & $\bullet \bullet \bullet$ & 3.7 & 44.5 & 5.9 & $* * *$ \\
\hline SFA. ${ }^{2}$ & 12.2 & 18.0 & 3.5 & $\leftrightarrow \bullet$ & 12.4 & 18.6 & 3.7 & $* *+4$ \\
\hline MUEA & 11.3 & 17.8 & 3.6 & 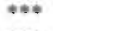 & 10.8 & 17.9 & 3.7 & $* \infty$ \\
\hline PUFA & 5.1 & 8.2 & 2.8 & *⿻一; & 4.3 & 7.9 & 2.8 & 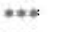 \\
\hline Carbohydrates & $47: 8$ & 38.1 & 7.1 & 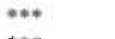 & 50.0 & 38.5 & 7.8 & $* * * i$ \\
\hline total $\mathrm{MD}^{2}$ & 23.9 & 17.1 & 6.5 & to* & 27.8 & 182 & 7.5 & $* *$ \\
\hline added MDi & 13.6 & 9.5 & 6.2 & enent & 11.6 & 9.8 & 6.2 & $*$ \\
\hline Polysaccharides & 22.7 & 20.5 & 4.4 & $* * *$ & 21.9 & 201.1 & 4.8 & ** \\
\hline Alcohol ${ }^{3}$ & 5.8 & 2.0 & & entip & 2.2 & 1.1 & & $* * *$ \\
\hline \multicolumn{9}{|c|}{ Inrake expressed per $M J$} \\
\hline Calcium (mg) & 93 & 90 & & & 134 & 101 & & ***: \\
\hline $\operatorname{lron}(\mathrm{mg})^{3}$ & 1.2 & 1.2 & & & 1.6 & I. 2 & & ***; \\
\hline Thiamin $(\mu g)^{3}$ & 107 & 104 & & & $13 !$ & 106 & & $4 * \infty$ \\
\hline Ribollavin $(\mu g)^{3}$ & 164 & 146 & & $+*+\infty$ & 209 & 156 & & $* * *$ \\
\hline Vitamin B- $h(\mu g)^{3}$ & 128 & 128 & & & 161 & 130 & & $* * *$ \\
\hline Vitamin $\mathrm{C}(\mathrm{mg})^{3}$ & 5 & 5 & & & 10 & 6 & & ***: \\
\hline Cholesiterol (mg) ${ }^{3}$ & 24 & 30 & & $\$ * *$ & 27 & 33 & & $* * *:$ \\
\hline Dielary fibre $(\mathrm{g})^{3}$ & 2.3 & 2. 2 & & & 2.9 & 2.2 & & $* * *$ \\
\hline
\end{tabular}

'Statistical significant difference between groups with different levels of fat intahe: " $P<0.05$ : *" $\mathbf{P}<0.01$; ** $\mathbf{P}<0.001$.

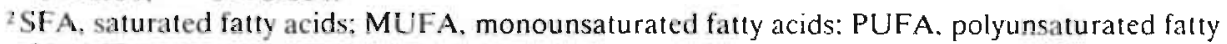
acids; MD, mono- and disaccharides.

${ }^{3}$ Only geometric means are shown. Log transformation is used for significance tests.

ethanol $)\left(x^{2}=81.68, P<0.001\right)$. Forty-eight percent of women with a low fat intake and $56 \%$ with a high fat intake did not drink, whereas 21 and $8 \%$, respectively, drank three or more glasses a day $\left(x^{2}=31.88, P<0.001\right)$. Men, but not women, with a relatively low fat intake consumed more sugar products than did those in the high-fat group. Among women more vegetables and fruit, but less bread and eggs, were consumed by the low-fat group. Also within food groups there were differences in consumed amounts. Those having a low fat intake used more skimmed milk products, lean meat, low-fat cheese and more low-fat spread (only for men).

Among men, fat intake (en\%) was neither associated with sociodemographic variables (education, socio-economic status, household size) nor with smoking habits or dietary regimen. The proportion of women with a dietary regimen ( 14.9 vs. $\left.3.8 \%, x^{2}=30.70, P<0.001\right)$ (mainly energyrestricted), as well as the proportion of women living alone, was higher among women having a relatively low fat intake $\left(23.4\right.$ vs. $12.3 \%, x^{2}=17.28$, $P<0.001)$. Mean age differed among the groups of men $(36.0$ years in the low- 
Tablc 4.6. Mean daily consumption of selected food groups ( $\mathrm{g}$ ) among men and women aged $22-49$. according to adjusted fat intake ( $<35$ and $\geq 40 \%$ of total energy intake, en\%).

\begin{tabular}{|c|c|c|c|c|c|c|}
\hline \multirow{2}{*}{ Food group } & \multicolumn{3}{|l|}{ Men } & \multicolumn{3}{|l|}{ Women } \\
\hline & $\begin{array}{l}<35 \text { en\% } \\
(n=183)\end{array}$ & $\begin{array}{l}\geq 40 \text { en } \% \\
(n=640)\end{array}$ & sign. ${ }^{\prime}$ & $\begin{array}{c}<35 \mathrm{en} \% \\
(n=154)\end{array}$ & $\begin{array}{l}\geq 40 \text { en\% } \\
(n=807)\end{array}$ & sign. \\
\hline Potatoes & 135 & 176 & $\cdots$ & 79 & 125 & $* *$ \\
\hline Vegelables & 164 & 160 & & 164 & 140 & $*$ \\
\hline Fruits & 115 & 106 & & 160 & 97 & $\cdots$ \\
\hline Cireals & 61 & 36 & $* *$ & 44 & 32 & $*$ \\
\hline Bread & 172 & 178 & & 108 & 120 & $* *$ \\
\hline Milk (products) & 260 & 250 & & 338 & 295 & \\
\hline Chase & 28 & 39 & $\cdots$ & 28 & 34 & $*$ \\
\hline Eggs & 16 & 20 & & 14 & 19 & $*$ \\
\hline Meat (products) & 127 & 158 & $\cdots$ & 84 & 116 & $* * *$ \\
\hline Fish & 8 & 11 & & 7 & 8 & \\
\hline Edible fats & 43 & 70 & $* * *$ & 21 & 49 & $* * *$ \\
\hline Pastry, biscuits & 30 & $4 \mathrm{l}$ & $* *$ & 28 & 46 & $* * *$ \\
\hline Sugar (products) & 66 & 53 & $\cdots$ & 45 & 36 & \\
\hline Nuts, savoury snacks & 15 & 37 & $* * *$ & 10 & 29 & ***; \\
\hline Alcoholic beverages & 790 & 335 & $* * *$ & 191 & 91 & $* * *$ \\
\hline
\end{tabular}

1 Statistically significant difference between groups with different levels of fat intake: ${ }^{*} P<0.05$ : ${ }^{* *} P<0.01 ; * * P<0.001$.

fat group vs. 34.7 years in the high-fat group, $P<0.05$ ). Mean values for body height, body weight and BMI did not differ significantly according to level of fat intake (en\%).

\section{Discussion}

For a strategy targeted at risk groups a valid estimate of the prevalence of a particular risk is necessary to monitor change and to quantify health risks. We found that the mean and median values for total fat as well as SFA and dietary fibre differ considerably from the guidelines. Consequently, the proportion of those not having a diet in accord with these guidelines was $>50 \%$. Only about $20 \%$ obtained $<35 \%$ of their energy from fat. However, a 2-day record does not measure habitual intake of an individual and an assessment based on such a method will exaggerate the range and prevalence values for both high and low intakes. With the knowledge on variance ratios the distribution obtained with 2-day records can be adjusted as a proxy for distributions of 'usual' intake. Since effects on health will occur in the long run, prevalence values as for high fat intake obtained from adjusted distributions are likely to reflect diet-related health risks in a population in a more appropriate way. Adjustment for within-person variance resulted in lower prevalence values for both high and low levels of intake. As, by definition, the degree of adjustment depends on deviation from mean values, prevalence values were affected 
most for those nutrients for which the average intake levels deviated most from the target, i.e., total fat, SFA and dietary fibre.

After adjustment about $16 \%$ of the total population met the guideline for tota] fat. In another nationwide survey in the Netherlands, assessing habitual dietary intake (23), prevalences were found to be closer to the unadjusted than to the adjustcd values of the present study. (For instance, a fat intake $<35$ en\% was found in $19 \%$ of men and $20 \%$ of women aged $65-79$, whereas in $50 \%$ and $43 \%$ of these groups, respectively, a cholesterol intake $\leq 33 \mathrm{mg} / \mathrm{MJ}$ was observed.) This inconsistency may be due to an overestimation of the within-person variation which is calculated from records of 2 consecutive days, and to the dependence of this variance component on the level of intake (lower within-person variance at lower intake lev(l). In our opinion, the observed unadjusted prevalence values, based on the mean of 2 days, are not likely to present a very unrealistic picture of habitual intake levels, at least for the elderly. More studies, especially among other age-sex groups, are needed to investigate the effects of these adjustments on the distribution of nutrients based on records obtained during more than 2 non-consecutive days.

Comparisons with results from other surveys might already provide suggestive evidence for the degree of differences between data that refer to short-and longerterm intake levels. However, such a comparison is only valid when mean (distributions of) intake levels are comparable. Overall, dietary intake characteristics among the Dutch population are typical of an 'affluent diet' with an excess of energy-dense foodstuffs that are rich in fat and MD, but with a relatively low contribution of complex carbohydrate foods (the main source of dietary fibre) (2). Our results among adults are in agreement with findings in other Western countries. Several European studies indicate that fat accounts for $37-41 \%$ of energy intake, SFA for $15-17 \%$, protein for $14-16 \%$, carbohydrates for $37-47 \%$, and alcohol for $2-9 \%(24-33)$. In the USA fat intake is slightly lower than in most European countries, but intake levels are still higher than recommended. According to the latest national surveys available to estimate nutrient intakes (USDA Continuing Survey of Food Intakes of Individuals, CSFII), in the diet of adults fat provides $36-37 \%$ of energy intake, SFA $13-14 \%$, carbohydrates $44+4 \%$, protein $15-17 \%$, and alcohol $1-3 \%(1)$.

Concerning prevalence estimates, percentages of subjects with a fat intake accounting for $\leq 35 \%$ of total energy (including alcohol derived energy) are roughly in line with our unadjusted results. Seven-day records among adults in the UK revealed prevalence values ranging from 20 to $28 \%$ for men $(25,27,30)$ and from 10 to $20 \%$ for women (25,30). In a Danish survey, using a dietary history method (32), only one of ten Danes aged 15-80 achieved that goal for fat. Results of 7-day dietary records revealed that in southern Germany, as well as in the UK, only $7 \%$ of both men aged 45-64 and men aged 16-64, and 4\% of women aged 16-64 achieved the recent WHO population goal for total fat (2), with an upper limit of $30 \%$ of total energy intake (30.33). Based on 4-day dietary intake data in the USA $10 \%$ of women complied with such an intake (1). In our study about $6 \%$ (unadjusted values) or $2 \%$ 
(adjusted values) of both men and women met this target. Other studies also report low proportions of those meeting the goal for SFA; in the UK and southern Germany $<4 \%$ of adults had diets with $\leq 10 \%$ SFA $(27,33)$ and hardly any subject met all dietary goals $(29,33)$. These results cast doubt on the actual realization of all dietary goals, and call for priorities in the goals. Given the present intake levels one can question the feasibility of the SFA goal. In our study, even in the low-fat groups (mean intake 32 en\% fat) SFA accounted for $12 \%$ of total energy intake.

Our findings among subjects aged 22-49 show that alcohol use had a strong effect on results. For both men and women we found a substantial difference in proportion of alcohol users and in amounts consumed between the low-and high-fat groups. Alcohol can be an important source of energy on a particular day, affucting dietary variables related to energy such as en $\%$ of total fat. The I utch guidelines for a healthy diet state that excessive alcohol consumption should be avoided (9) without (as in many other countries [2]) specifying what moderate alcohol use is supposed to be. At present, it is not clear whether the recommendations refer to intake inclusive or exclusive of energy from alcohol. Recent UK dietary reference values (34) distinguish recommendations based on total energy intake (including alcohol) and those based on food energy (without alcohol); for total fat the guideline is $33 \%$ of total energy and $35 \%$ of food energy. SFA should provide, on average, $10 \%$ of total energy or $11 \%$ of food energy at the most, and total carbohydrates 47 and $50 \%$, respectively, on a population level. In our study, excluding energy from alcohol, about $13 \%$ of men and $15 \%$ of women $\geq 16$ years had diets with $<35$ en $\%$ from fat. Differences in alcohol intake at least partly explain why men appear to be more likely to achieve dietary goals than do women. In evaluating dietary intake of fat the consumption of alcohol may hamper interpretation. Achievement of a low fat intake, expressed as a percentage of energy, by means of a high intake of alcohol is undesirable. Therefore, in setting dietary guidelines it is crucial to formulate whether energy-related recommendations include energy derived from alcohol.

Alcohol intake will contribute to energy intake, whereas several studies suggest an inverse relationship between alcohol intake and BMI (35-38). Whether energy from alcohol is completely utilized by the human body is being challenged $(7,8)$. In our study we grouped subjects by fat intake rather than by alcohol consumption. Despite higher energy and lower alcohol intake among subjects consuming $\geq 40$ en\% from fat, no significant differences in body weight and BMI were observed. When we examined energy intake without the contribution of alcohol, an even more pronounced difference in energy intake by level of fat consumption was observed (20\% among men and 34\% among women instead of the original differences of $13 \%$ and $29 \%$, respectively). Systematic underreporting of alcohol only among those with a relatively high fat intake is not likely. Our results therefore suggest differences in physical activity according to fat intake. Unfortunately, in our study we have not obtained information on physical activity.

Our study confirms previous findings that, besides intake of alcohol, MD lower the contribution of fat to energy intake $(4,39)$. For both men and women an inverse 
relationship was observed between the percentage of dietary energy derived from fat and that from MD $[r=-0.61$; range -0.47 (adults) to -0.84 (children, adolescents)]. However, among men aged 22-49 grouped by fat intake, only sugar intake differed significantly, whereas in both sex groups the consumption of pastries and biscuits was even higher in the high-fat group. Substantial effects of slimming diets are not likely, since after excluding these dieters similar results for the mentioned food groups were found, and only significant differences in intake of bread, vegetables and eggs between women with a relatively high and a low fat intake (en\%) disappeared. One of the effects of a high (absolute) intake of MD is a lower nutrient density of the diet (40-44). In our study, however, we found (especially among women) that a low fat intake and a high (added) MD intake (both expressed in en\%) were related to higher nutrient density. This may be explained by the finding that in both men and women the average intake of added MD was < 15 en\%. Specifying the guideline for MD as added MD will prevent that data are contaminated with the contribution of naturally occurring MD such as those from milk products and fruit, and thus will simplify dietary evaluation.

\section{Conclusions}

Based on the Dutch guidelines for a healthy diet and data of the first DNFCS it is concluded that the goals for fat, dietary fibre and-especially-SFA are difficult to achieve. Our results illustrate the possibilities to meet the guideline for fat by consuming less edible fats, cheese and meat products and more skimmed milk and lean meat products. However, a low fat intake does not guarantee that SFA intake will conform to the guidelines. In addition, our results suggest that a high fat intake is less affected by the method of food consumption assessment (2-day records vs. habitual intake) than by the calculation method, particularly with respect to the contribution of alcohol to energy intake. Therefore, we recommend that future guidelines state explicitly whether alcohol should or should not be included in the calculations.

\section{References}

1. National Research Council. Diet and Health: Implications for Reducing Chronic Discase Risk. Washington. DC: National Academic Press. 1989.

2. World Health Organization. Diet. Nutrition and the Prevention of Chronic Diseases. Report of a WHO Study Group. Geneva: World Health Organization. Technical

Report Serics 797, 1990.

3. Cannon GJ. The Experts Agree. London: Consumers' Association. 1991.

4. (ibney MJ. Dietary guidelin's: a critical appraisal. J Hum Nutr Diet 1990;3: $245-254$.

5. Gibney MJ. The disadvantiges of quantitative dietary recommendations. Br J Nutr 1990:64: 303-304. 
6. Voortgangsrapportage Voedingsbeleid. The Hague: Ministry of Welfare, Public Health and Cultural Affairs. 1987.

7. Gruchow HW. Sobocinski KA. Barboriac JJ, Sheller JG. Alcohol consumption, nutrient intake and relative body weight among US adults. Am J Clin Nutr 1985;42: $289-295$.

8. Lands EM. Zakhari S. The case of missing calories. Am J Clin Nutr 1991;54: 47-48.

9. Netherlands Nutrition Council. Guidelines for a Healthy Diet. The Hague: Voedingsraid. 1986.

10. Netherlands Nutrition Council. Reassessment of the Advice on Fat Consumption Contained in Guidelines for a Healthy Diet 1986. The Hague: Voedingsraad 1991.

11. Beaton GH. What do we think we are estimating? In Beal VA. Laus MJ (eds): Proceedings of the Symposium on Dietary Data Collection, Analysis and Significance. Amherst: Massachusetts Agricultural Research Station, University of Massachusetts, Research Bulletin No 675, 1982.

12. Anderson SA. Guidelines for use of dietary intake data. Bethesda. MD: Life Sciences Research Office. Federation of American Societies for Experimental Biology, 1986.

13. Sempos CT, Looker AC, Johnson CL. Woteki CE. The importance of within-person variability in estimating prevalence. In McDonald I (ed): Monitoring Dietary Intakes. Berlin Heidelberg: Springer-Verlag. 1991: 99-109.

14. Löwik MRH, Hermus RJJ. The Dutch nutrition surveillance system. Food Policy 1988:13: 359-365.

15. Hulshof KFAM, Van Staveren WA. The Dutch National Food Consumption Survey: design. methods and first results. Food Policy 1991;16: 257-260.

16. NEVO-tabel: Nederlands Voedingsstoffenbestand 1986-1987. The Hague: Voorlichtingsbureau voor de Voeding. 1987.

17. Dixon WJ. Brown MB. Engelsman L. Frane JW, Hill MA. Jennrich RI. Toperek JD BMDP Statistical Software. Berkeley: University of California Press, 1990.

18. Clarck AJ. Mossholder S. Sodium and potassium intake measurements: dietary mcthodology problems. Am J Clin Nutr 1986:43: 470-476.

19. Genstat. A General Statistical Program. Oxford: Numerical Algorithms Group Lid. 1980.

20. National Research Council. Nutrient Adequacy. Assessment Using Food Consumption Surveys. Washington, DC: National Academic Press, 1986.

21. Siegel S. Nonparametric Statistics. New York: McGraw-Hill, 1956.

22. Garrow JS. Treat Obesity Seriously. London: Churchill Livingstone, 1981.

23. Lowik MRH. Westenbrink S. Hulshof KFAM, Kistemaker C. Hermus RJJ. Nutrition and aging: dietary intake of 'apparently healthy' elderly (Dutch Nutrition Surveillance System). J Am Coll Nutr 1989:9: 347-356.

24. Fehily AM. Phillips KM. Sweetnam PM. A weighed dietary survey of men in Caerphilly, South Wales. Hum Nutr Appl Nutr 1984;38A: 270-276.

25. Nelson M. Nutritional goals from COMA and NACNE: How can they be achieved. Hum Nutr Appl Nutr 1985:39A: 456-464.

26. Barasi ME. Phillips KM. Burr ML. A weighed dietary survey of women in South Wales. Hum Nutr Appl Nutr 1985:39A: 189-194.

27. Thomson M. Fulton M. Wood DA, Brown S. Elton RA, Birthwhistle A, Oliver MF. A comparison of the nutrient intake of some Scotsmen with dietary recommendations. Hum Nutr Appl Nutr 1985:39A: 443-445.

28. Thompson RL. Cruickshank JK. Ellis LJ, Walker AO. Fox TE, Miller GJ. Dictary intake of men in Wembley (London), by weighed inventory: comparison with national recommendations, with particular emphasis on fat intake. Eur J Clin Nutr 1989:43: 245-251.

29. Cade JE. Margetts BM. Dietary patterns in threc English towns in relation to dietary goals and RDAs. J Hum Nutr Diet 1989:2: 49--54.

30. Gregory J. Foster K. Tyler H. Wiseman M. The Dietary and Nutritional Survey among British Adults. London: HSMO. 1990. 
31. Strain JJ, Barker ME, Livingstone MB, McKenna PG. The Northern Ireland dietary survey and related studies. Proc Nutr Soc 1990;49: 289-296.

32. Haraldsdóttir J. Holm L, Højmark Jensen J, Møller A. Danskernes Kostvaner 1985. 1. Hovedresultater. Seborg: Miljøministeriet Levnedsmiddelstryrelsen, Publikation nr. 136, 1986.

33. Winkler G, Döring A, Keil U. Selected nutrient intakes of middle-aged men in southern Germany: results from the WHO MONICA Augsburg Dietary Survey of 1984/1985. Ann Nutr Metab 1991:35: 284-291.

34. Panel on Dietary Reference Values of the Committee on Medical Aspucts of Food Policy. Dietary Reference Values for Food Energy and Nutrients for the United Kingdom. London: HMSO, Report on Health and Social Subjects no 41. 1991.

35. Jones BR, Barrett-Connor E, Criqui MH. Holdbrook MJ. A community study of calorie and nutrient intake in drinkers and nondrinkers of alcohol. Am J Clin Nutr 1982:35: 135-139.

36. Fisher M, Gordon T. The relation of drinking and smoking habits to diet: The Lipid Research Clinics Prevalence: Study. Am J Clin Nutr 1985:41: 623-630.

37. Williamson DF. Forman MR, Binkin NJ. Gentry IM. Remington PL. Trowbridge FL. Alcohol and body weight in United States adults. Am J Public Health 1987:77: 1324-1330.

38. Colditz GA. Giovannucci E. Rimm EB. Stampfer MJ, Rosner B. Speizer FE. Gordis E, Willett WC. Alcohol intake in relation to diet and obesity in women and men. Am J Clin Nutr 1991:54: 49-55.

39. Gibney MJ, Lee P. Formulation of practical advice for reducing dietary fat intakes in unemployed in Dublin. J Hum Nutr Diet 1991:4: 179-184.

40. Glinsman WH, Irausquin H. Park YK. Evaluation of health aspects of sugars contained in carbohydrate sweeteners. J Nutr 1986:116: S1-S216.

41. Dowle W, Sanderson M, Wyn AHA. Nutrient intakes of high- and low-sugar consumers during pregnancy. Proc Nutr Soc 1989;48: 46A.

42. Gibney MJ, Lee $\mathbf{P}$. Patterns of food and nutrition intake in the chronically unemployment consuming high and low levels of table sugar. Proc Nutr Soc 1989;48: 132A.

43. Rugg-Gunn AJ, Hackett AF, Jenkins GN. Appleton DR. Empty calories? Nutrient intake in relation to sugar intake in English adolescents. J Hum Nutr 1991:4: $101-111$.

44. Löwik MRH. Kistemaker C. Aken AMMAM van. De voeding bij verschillende niveau's van toegevoegde mono- en disacchariden. Zeist: TNO-Voeding, Report nr V $91.530,1991$. 


\title{
Diet and other life-style factors in high and low socio- economic groups (Dutch Nutrition Surveillance System)
}

\author{
K.F.A.M. Hulshof, M.R.H. Löwik, F.J. Kok, M. Wedel, H.A.M. Brants, \\ R.J.J. Hermus, F. ten Hoor
}

\begin{abstract}
Insight into the occurrence of and the association between certain socio-economic variables and life-style characteristics is necessary for preventive nutrition and health policy. The prevalence of and the interdependences among these variables were examined in 1930 men and 2204 women aged 19 to 85 who participated in the 1987-1988 Dutch National Food Consumption Survey. Dietary data were based on a two-day record. The associations among discrete variables were analysed using loglinear models. Analysis of covariance was used to explore the effects of the aggregate socio-economic status (SES) on dietary intake and anthropometry, whereas differences in food intake and SES were assesscd by the non-parametric test of Kruskal and Wallis. In comparison to subjects with a high SES in people with a low SES a higher proportion of smokers ( 48 vs. $32 \%$ ) was observed, a higher prevalence of obesity ( 39 vs. $28 \%$ ), a higher percentage of heavy coffee drinkers (more than six cups per day, 23 vs. 17\%), and more subjects who skipped breakfast (19 vs. 11\%). In the highest SES class more subjects used nutritional supplements (18 vs. $11 \%$ ), more persons followed a dietary rule ( 5 vs. $2 \%$ ), such as a vegetarian diet, and a higher proportion used more than three alcoholic drinks per day (19 vs. 15\%). A higher SES was associated with a lower fat intake, but the differences (expressed as \% of energy intake) were rather small and even absent among women when the contribution of alcohol to energy was not taken into account. In general, dietary intake among subjects in higher SES groups tended to be closer to dietary recommendations. The results indicate that a lower SES is accompanied with a higher prevalence of several indicators of an unhealthy life-style.
\end{abstract}




\section{Introduction}

Standardized morbidity and mortality are inversely related with socio-economic status (SES) in a variety of countries (1-4). In Great Britain, Marmot \& McDowall (5) showed that social differences in morbidity and mortality became larger between 1970 and 1983 in spite of general improvement of health. Although it is not clear how these differences can be explained, there is evidence that some risk factors, such as an unfavourable life-style, have higher prevalence in lower socio-economic strata. Cigarette smoking is inversely related with SES (6-8). Marmot et al. (9) found that the reversal for ischaemic heart disease from a high-class disease to a lower-class disease occurred when the higher class began to use less tobacco and sugar, and to eat more wholemeal bread in comparison to the lower class. Other population-based studies also have shown that cardiovascular risk factors are more prevalent among lower socio-economic strata in affluent societies (10-13).

Food consumption studies fail to give a consistent picture of socio-demographic differences in dietary patterns. In some studies the consumption pattern is unaffected by socio-demographic factors, whereas in others age, gender, SES, race or region have an influence on the quality or quantity of food consumption (14-18).

In the Netherlands the impact of socio-economic factors on health is a topic of considerable concern since mortality and morbidity are still inversely associated with SES. To obtain insight into the association of some life-style factors with current socio-economic variables, we studied the prevalence of and the interdependences among life-style factors in various socio-economic strata among adults who participated in the 1987-1988 Dutch National Food Consumption Survey.

\section{Subjects and methods}

As part of the Dutch nutrition surveillance system, a national food consumption survey was conducted in the Netherlands in 1987-1988 $(19,20)$. This survey comprises 2203 households selected from a panel by a stratified probability sample among non-institutionalized households. Actually, 5898 persons living in the selected households, aged 1-85, participated (response rate $81 \%$ ). In the present study analyses are based on individuals aged 19 years and over. Younger people were excluded because life-style characteristics and food consumption patterns for children, adolescents and adults differ and therefore should be studied separately. Because pregnancy may affect dietary habits, pregnant women $(n=52)$ were excluded. In total, 4134 individuals ( 1930 men and 2204 women) remained for statistical analysis.

Information on food intake was collected by means of a two-day record method. The methods regarding data collection are described in detail elsewhere (20). Intake of energy and nutrients was calculated with an extended computerized version of the 1986/1987 Dutch food composition table (21). For each individual the average intake over two days was calculated. Nutritional supplements were not included in 
the calculation of nutrient intake. The foods were classified into 23 major food. groups and 32 subgroups, classification being based on similarity in nutrient composition and/or origin.

In addition to the food consumption data, information was collected on the respondent's body weight, height (both self-reported figures), use of nutritional supplements, special dietary practices, smoking habits, meal pattern and hours of sleep during the two consecutive days of the survey by means of a structured questionnaire included in the personal diary. Information about education, occupation, socio-economic status and demographic background (i.e. region, degree of urbanization) were already known to the Marketing Research Institute AGBAttwood which carried out the field work.

Three levels of education were distinguished: low level (primary school and low vocational training), intermediate (middle) level (secondary school and intermediate vocational training) and high level (university and high vocational training). Sociueconomic status, based on educational level, occupation and occupational position, was categorized into low, middle and high (see Table 5.1 for some examples of occupations according to SES). The associations among discrete variables were analysed with log-linear models (22). The factors were SES, age and gender on the one hand, and health-related life-style factors (23-28), namely smoking, obesity based on body mass index (BMI) according to Garrow (29), special dietary habits, breakfast habits, use of nutritional supplements, use of alcohol and use of coffee on the other.

Table 5.1. Examples of occupations' belonging to different socio-economic categories.

\section{High SES}

medical specialist, physician, lawyer, university graduate engineer, director, executive manager supervising at least 10 persons. accountant, senior administrator. cotonel in the army, farmer owning at least 20 ha of land, self-employed shopkeeper (e.g. butcher, grocer) employing at least 5 persons.

\section{Intermediate SES}

nurse. dietitian. laboratory technician with intermediate or high vocational training, manager supervising lees tan 10 persons. director's secretary, assistant accountant, teacher (primary school), warrant officer in the army. housewife with high or secondary education, student with high or secondary education, farmer owning 5-19 ha of land, self-employed shopkeeper (c.g. butcher, grocer) employing $1-4$ persons.

\section{Low SES}

blue-collar labourer, porter. warehouseman, cleaning woman, typist with low education, postman, chauffeur, corporal in the army, housewife with low education. student with low education, farmer owning less than 5 ha of land, shop assistant.

\footnotetext{
${ }^{1}$ The highest level within a household.
} 
Comparisons of the dietary intake figures among SES categories were made on sex-specific means, adjusted for age by analysis of covariance using BMDP Statistical Software (30). The assumptions underlying the analysis of variance regarding the residuals (equality of variance and normality) were checked before the analysis was carried out. When a distribution was skewed (as was the case for alcohol, riboflavin, vitamin $\mathrm{C}$, thiamin per $\mathrm{MJ}$ and $\mathrm{P} / \mathrm{S}$ ratio) values were transformed logarithmically. Out-of-range values were excluded from both the descriptive statistics and the analysis. Due to their non-normal distribution, intake of food groups had to be analysed with non-parametric methods (31), using the statistical computer package BMDP (30). All statistical tests were two-tailed, and differences with a $P$ value of less than 0.05 were considered statistically significant.

\section{Results}

\section{Socio-demographic characteristics}

The mean age of both men and women was nearly 43 years. Of the participants $10 \%$ were $19-24$ yr, $57 \%$ were $25-49$ yr, $21 \%$ were $50-64$ yr and $12 \%$ were 65 yr or over. Almost half of the population belonged to the stratum with low SES and $10 \%$ to the highest stratum.

As expected, education, age, SES and gender were strongly associated. Respondents aged 65 and over were overrepresented in the low SES class, whereas in the middle and high classes more subjects were aged 25-49. Subjects of the high SES class aged 50 or over had more frequently a low or middle level of education than the younger ones ( $13 \%$ and $49 \%$ vs. $5 \%$ and $38 \%$, respectively). Persons with a high education and a low SES were mainly found in the youngest age group (34\%). Furthermore, the educational level of women in the high social class was lower than that of men in the same class (women: $13 \%$ low, $50 \%$ intermediate level of education; men: $2 \%$ and $31 \%$, respectively).

Regarding life-style, anthropometry and food consumption pattern, those belonging to the middle SES group held mostly an intermediate position. Since the largest differences were found between the low and the high SES the results of these groups are presented only.

\section{Life-style characteristics}

Gender, age and SES on their own affected most of the life-style characteristics studied. However, only ficw interactions were observed. In general, a dietary regimen and the usage of nutritional supplements were highest in (elderly) women, whereas more men (especially those aged 25-49) than women were heavy coffee drinkers and alcohol users.

Table 5.2 presents the associations of SES with life-style variables. Subjects with a higher SES more often followed a special dietary rule, such as a vegetarian diet. No 
Table 5.2. Socio-demographic and other characteristics according to SES class.

$$
\begin{array}{ll}
\text { Low SES }(\%) & \text { High SES }(\%) \\
(n=1976) & \text { Sign. }{ }^{1}
\end{array}
$$

Dietary pattern

- Special dietary rule

- Use of nutritional supplements

- Skipping breakfast on both days one day only

$\begin{array}{rrr}2 & 5 & * \\ 11 & 18 & * \\ 10 & 4 & \\ 9 & 7 & \\ 45 & 32 & \cdots \\ & & \\ 50 & 36 & \\ 25 & 32 & \\ 10 & 12 & \\ 15 & 19 & \\ & & \\ 7 & 10 & \\ 28 & 35 & \\ 41 & 38 & \\ 23 & 17 & \\ & & \\ 10 & 10 & \\ 40 & 47 & \\ 50 & 43 & \\ & & \\ 31 & 23 & \\ 8 & 5 & \end{array}$

Smokers

Alcoholic drinks per day none

$<2$ glasses

2-3 glasses

$>3$ glasses

Coffee per day

$<1$ cup

$1-3$ cups

4-6 cups

$\geq 7$ cups

Night's rest

$<7$ hours

7-8 hours

$\geq 9$ hours

Body mass index

overweigt (BMI $25.0-29.9 \mathrm{~kg} / \mathrm{m}^{2}$ )

obese (BMI $\geq 30 \mathrm{~kg} / \mathrm{m}^{2}$ )

ents

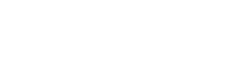

I

${ }^{*} P<0.05 ;{ }^{* *} P<0.01 ; * * P<0.001$; @ significant interaction between $\mathrm{SES}$ and age groups. see also Fig. 5.1.

association was found between a prescribed diet and SES. Supplements were more frequently used by subjects with a higher SES. During the record days the percentage of subjects skipping breakfast was lowest in the high SES class. When alcohol consumption during the record days was categorized in glasses consumed per day, a consumption level of more than three glasses was highest among subjects with a higher SES. In contrast with alcohol consumption, a relatively high coffee consumption was more frequently observed in the stratum with low SES and the lowest consumption in the high SES stratum. In the low SES class the highest proportion of subjects sleeping nine or more hours was found, whereas the proportion of those sleeping seven to eight hours on average was highest in the high SES class. 


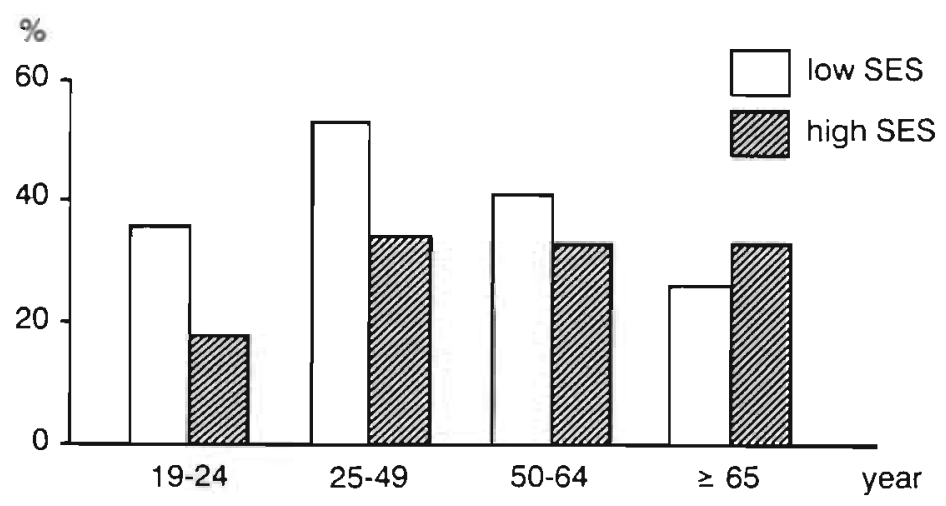

Fig. 5.1. Smokers (\%) by SES and age.

Except for the youngest age group, in which about one third of both men and women were smokers, the percentage of smokers was highest among men. In most age groups smoking and SES were inversely associated. However, among those aged 65 or over the highest proportion of smokers was observed in the high SES class (Fig. 5.1).

\section{Anthropometry}

After adjustment for age, men and women in the lower class were shorter and had the highest BMI (Table 5.3). Overweight (BMI $25.0-29.9 \mathrm{~kg} / \mathrm{m}^{2}$ ) was highest in men, whereas particularly in (elderly) women, the percentage with obesity (BMI $\geq 30$ $\mathrm{kg} / \mathrm{m}^{2}$ ) was highest. The highest prevalence of both overweight and obesity was observed in the low SES class (Table 5.3).

Table 5.3. Anthropometric variables (mean values and (pooled) SD) according to SES and gender.

\begin{tabular}{|c|c|c|c|c|c|c|}
\hline \multirow[t]{2}{*}{ Variable } & \multicolumn{3}{|l|}{ Men } & \multicolumn{3}{|l|}{ Women } \\
\hline & $\begin{array}{l}\text { low SES } \\
(n=933)\end{array}$ & $\begin{array}{l}\text { high SES } \\
(n=189)\end{array}$ & $\mathrm{SD}^{1}$ & $\begin{array}{l}\text { low SES } \\
(n=1043)\end{array}$ & $\begin{array}{l}\text { high SES } \\
(n=228)\end{array}$ & SD \\
\hline Height $(\mathrm{cm})$ & 177.9 & 180.4 & $(7.1)^{* * *}$ & 166.5 & 167.7 & $(6.3)^{* *}$ \\
\hline Weight (kg) & 77.9 & 78.2 & $(10.5)$ & 67.5 & 65.7 & $(10.8)^{*}$ \\
\hline $\mathrm{BMI}\left(\mathrm{kg} / \mathrm{m}^{2}\right)$ & 24.6 & 24.0 & $(2.9)^{* * *}$ & 24.4 & 23.3 & $(3.6)^{* * *}$ \\
\hline
\end{tabular}

${ }^{1} \mathrm{SD}$. standard deviation. Statistically significant difference between SES classes, adjusted for the effects of age: ${ }^{*} P<0.05 ;{ }^{* *} P<0.01$; $^{* * *} P<0.001$. 
In Table 5.4 the intake of energy and nutrients is presented according to SES and gender. In general, men had a higher energy intake than women. For both men and women, energy intake decreased with increasing age. The differences in macronutrient intake when expressed as a proportion of energy intake between men and women and among age groups were small. The percentage of energy derived from alcohol was lower for women, whereas the nutrient density (intake per MJ) was mostly higher for women than for men and higher in older than in younger age groups.

As shown in Table 5.4, men with a low SES had the highest intake of energy and more energy was derived from fat (total fat and monounsaturated and polyunsaturated fatty acids). The ratio between polyunsaturated and saturated fatty acids ( $\mathrm{P} / \mathrm{S}$ ratio) and vitamin $\mathrm{B}-6$ intake per gram protein was higher in the strata with a lower SES. Energy derived from alcohol and intake of dictary fibre, calcium and vitamin $C$ was significantly lower among men with a low SES.

Table 5.4. Mean daily intake of energy and nutrients (and pooled SD), according to SES (low and high) and gender.

\begin{tabular}{|c|c|c|c|c|c|c|c|c|}
\hline \multirow[t]{2}{*}{ Variable } & \multicolumn{4}{|l|}{ Men } & \multicolumn{4}{|l|}{ Wemen } \\
\hline & $\begin{array}{l}\text { low } \\
(n=933)\end{array}$ & $\begin{array}{l}\text { high } \\
(n=189)\end{array}$ & $\mathrm{SD}^{1}$ & & $\begin{array}{l}\text { low } \\
(n=1043)\end{array}$ & $\begin{array}{l}\text { high } \\
(n=228)\end{array}$ & SD & \\
\hline Energy $(\mathrm{MJ})^{2}$ & 11.8 & 11.2 & (28) & $\cdot$ & 8.5 & 8.5 & (2.3) & \\
\hline alcohol excl. (MJ) & 11.2 & 10.6 & (2.7) & *⿻一; & 8.3 & 8.2 & (2.3) & \\
\hline Protein $(\mathrm{en} \%)^{2}$ & 12.9 & 13.2 & $(2.8)$ & & 14.3 & 14.3 & $(3.5)$ & \\
\hline Fat $(e n \%)$ & 41.1 & 39.6 & $(6.7)$ & ***;: & 41.9 & 40.2 & $(7.4)$ & $* * *$ \\
\hline $\mathrm{SFA}^{2}(\mathrm{en} \%)$ & 16,5 & 17.0 & (3.3) & & 17.3 & 17.4 & (3.6) & \\
\hline MUFA $^{2}(\mathrm{en} \%)$ & 16.1 & 14.8 & (3.3) & $\because * *$ & 16.2 & 15.0 & (3.5) & $* *$ \\
\hline PUFA ${ }^{2}(\mathrm{en} \%)$ & 7.3 & 6.5 & $(2.7)$ & $* * * i$ & 7.1 & 0.3 & $(28)$ & $*$ \\
\hline P/S rations & 0.45 & 0.39 & & **: & 0.41 & 0. 37 & & $* *$ \\
\hline Cholesterol (mg/MJ) & 31 & 32 & (11) & & 34 & 351 & $(13)$ & \\
\hline Cârbohydrates (en\%) & 41.1 & 41.2 & $(7.1)$ & & 41.6 & 41.5 & $(7,6)$ & \\
\hline $\mathrm{MD}^{2}(\mathrm{en} \%)$ & 19.6 & 19.7 & $(6.6)$ & & 20.6 & 20.4 & (6. 7$)$ & \\
\hline Dielary fibre $(\mathrm{g} / \mathrm{MJ})$ & 2.3 & 2.5 & $(0.8)$ & * & 2.6 & 2.7 & $(09)$ & \\
\hline Alcohol (en\%)" & 2.4 & 3.2 & & $=$ & 0.9 & 1.9 & & $* * *$ \\
\hline Calcium (mg) & 1126 & 1226 & $(462)$ & $* n$ & 956 & 1063 & $(385)$ & $\bullet$ \\
\hline Iron (mg) & 13.6 & 14. I & $(4.0)$ & & 11.2 & 11.9 & (3.3) & $* *$ \\
\hline Thiamin $(\mu \mathrm{g} / \mathbf{M J})^{3}$ & 106 & 111 & & & 117 & 111 & & $\cdot$ \\
\hline Riboflavin $(\mathrm{mg})^{3}$ & 1.75 & 1.76 & & & 141 & 1.52 & & $* *$ \\
\hline Pyridoxine ( $\mu \mathrm{g} / \mathrm{g}$ protein) & 17.8 & 17.0 & (4.4) & $\cdot$ & 18.0 & 17.4 & (4.5) & \\
\hline Vitamin $C(\mathrm{mg})^{3}$ & 56 & 63 & & $*$ & $5 \xi$ & 70 & & $* * *$ \\
\hline
\end{tabular}

' SD, standard deviation. Statistically significant difference between SES classes, adjusted for the effects of age: ${ }^{*} P<0.05:{ }^{*} P<0.01 ;{ }^{* * *} P<0.001$.

${ }^{2} \mathrm{MJ}$, megajoule $(1 \mathrm{~J}=0.24 \mathrm{cal}: 1000 \mathrm{kcal}=4.184 \mathrm{MJ})$; en $\%$, \% of total energy intake: SFA. saturated fatty acids; MUFA. monounsaturated fatty acids; PUFA. polyunsaturated fatty acids; $\mathrm{P} / \mathrm{S}$ ratio, ratio between intake of polyunsaturated acids and intake of saturated fatty acids; $M D$. mono- and disaccharides.

${ }^{3}$ Geometric means are shown. Log transformation is used for significance tests. 
The associations of SES with macronutrients were similar for women and men although energy intake did not differ by sociu-economic class. Except for thiamin and vitamin B-6, the intake of minerals and vitamins was higher for the higher SES groups.

Since alcohol may confound the energy-related intake figures we also calculated the contribution of fat to energy exclusive of alcohol. Total fat now accounted for $43.2 \%$ and $42.2 \%(P<0.05)$, and saturated fatty acids for $17.4 \%$ and $18.0 \%$ $(P<0.01)$ for men in the low and the high SES group, respectively. Among women differences in contribution of total fat were no longer observed (both groups $41.9 \%$ ), whereas women in the low SES class had a lower contribution of saturated fatty acids $(17.7 \%$ vs. $18.2 \%, P<0.01)$.

\section{Consumption of food groups}

As expected (due to the higher energy intake and requirement), for most food groups men tended to have a higher consumption than women and younger adults had a higher consumption than those aged 50 and over. However, the consumption of fruits, vegetables (women only) and pastry/biscuits appeared to be higher in the older age groups.

Table 5.5 presents the consumption of food groups according to gender and

Table 5.5. Mean daily consumption of selected food groups (g) among men and women. according to SES class (low or high).

\begin{tabular}{|c|c|c|c|c|c|c|}
\hline \multirow[t]{2}{*}{ Food group } & \multicolumn{3}{|l|}{ Men } & \multicolumn{3}{|l|}{ Women } \\
\hline & $\begin{array}{l}\text { low } \\
(n=933)\end{array}$ & $\begin{array}{l}\text { high } \\
(n=189)\end{array}$ & sign. ${ }^{1}$ & $\begin{array}{l}\text { low } \\
(n=1043)\end{array}$ & $\begin{array}{l}\text { high } \\
(n=228)\end{array}$ & sign. \\
\hline Potatoes & 178 & 138 & * & 125 & 104 & * \\
\hline Vegetables & 158 & 171 & & 147 & 159 & \\
\hline Pulses & 7 & 9 & & 5 & 7 & \\
\hline Fruits & 119 & 131 & $*$ & 124 & 152 & $*$ \\
\hline Cercals & 37 & 45 & * & 29 & 35 & $*$ \\
\hline Bread & 177 & 166 & & $1: 0$ & 118 & \\
\hline Milk (products) & 342 & 370 & & 301 & 336 & \\
\hline Cheese & 34 & 43 & * & 28 & 37 & * \\
\hline Eggs & 20 & 18 & & 17 & 19 & \\
\hline Meat (products) & 153 & 126 & * & 116 & 97 & $*$ \\
\hline Fish & 11 & 11 & & 7 & 10 & \\
\hline Edible fats & 63 & 53 & * & 43 & 40 & \\
\hline Pastrics, biscuits & 39 & 45 & & 44 & 46 & \\
\hline Sugar (products) & 62 & 53 & $*$ & 37 & 34 & \\
\hline Nuts, savoury snacks & 26 & 26 & & 19 & 19 & \\
\hline Non-alcoholic beverages & 1151 & 1116 & & 1173 & 1147 & \\
\hline Alcoholic beverages & 399 & 358 & & 76 & 130 & * \\
\hline
\end{tabular}

It Stitistically significant difference between SES classis: * $P<0.05$. 
SES. Both for men and women the low SES class had the highest consumption of potatoes and meat, but the consumption of fruits, cereals and cheese was lowest. Men, but not women, with a low socio-economic background consumed more fats and sugar (products) than those in the higher classes. For women the consumption of alcoholic beverages was positively associated with SES.

Edible fats, milk (products), cheese and meat (products) are important fat sources. Within most of these food groups the contribution of subgroups (classified according to fat content) to total consumption differed among the SES groups. Although the total consumption of milk (products) was similar, the contribution of products with a low fat content, i.e. skimmed and low-fat milk, was higher in the high SES class. Similar results were observed with respect to lean vs. higher-fat meat varieties (Fig. 5.2). The contribution of low-fat spreads was slightly higher in the low SES group, whereas butter accounted for about $25 \%$ of edible fat intake in the high SES class and for only $10 \%$ in the lowest class. In all SES groups $14 \%$ to $17 \%$ of the edible fats came from polyunsaturated margarines/fats. Among subjects with a low SES the contribution of high-fibre cereals to total consumption appeared to be smaller than in the high SES group (6\% vs. $16 \%$ for men and $10 \%$ vs. $15 \%$ for women, respectively).

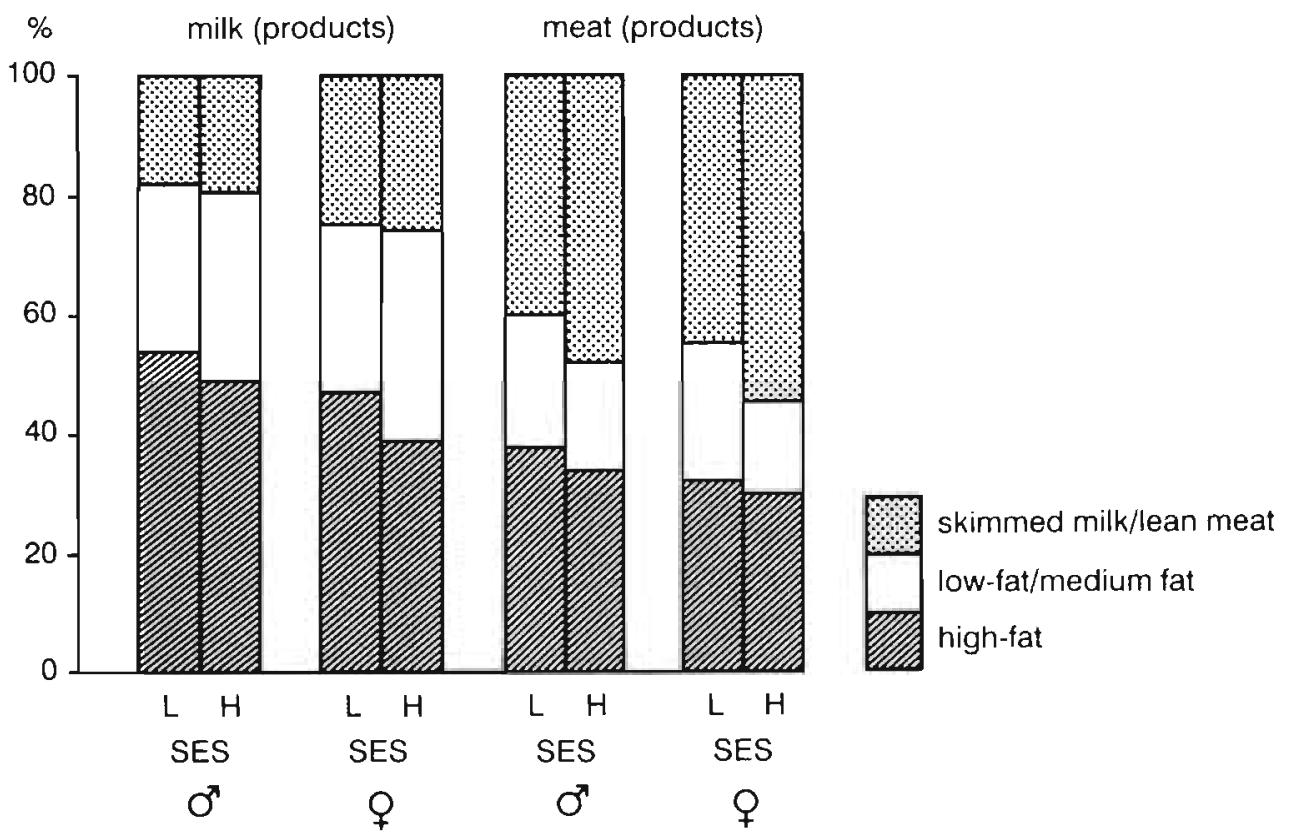

Fig. 5.2. Contribution (\%) of subgroups to the total consumption of food groups by SES and gender. 


\section{Discussion}

In this crusis-sectional study several associations of dietary intake and other life-style variables with SES were observed. Among subjects with a low SES we found a higher proportion of smokers (except for those aged 65 or over), a higher prevalence of obssity, a higher percentage of heavy coffee drinkers and more subjects who skipped breakfast.

The association of smoking with chronic disorders such as cancer and cardiovascular disease is well documented (32). Obesity is frequently associated with high blood pressure, diabetes and high blood lipid levels (32). The number of meals has been shown to be inversely related to obesity. Especially skipping breakfast is a habit which is more common among obese persons (33). A moderate consumption of alcohol (one to three glasses) is associated with lower risk of coronary heart disease (34). However, there appears to be a direct association between increased blood pressure and the consumption of alcohol at levels exceeding $30 \mathrm{~g}$ ethanol daily (32). Positive relationships have been observed between smoking and the consumption of alcohol and coffee $(24,35)$. Several studies show that coffee drinkers consume a more atherogenic diet (higher intake of saturated fat and cholesterol) than their non-coffee-drinking counterparts $(28,36,37)$. In fact, these life-style variables can be considered as indicators of health behaviour. Based on the higher prevalence of most of these indicators (alcohol consumption excluded) our study suggests that subjects with a lower SES are more prone to a potentially riskenhancing behaviour. The finding that in the higher SES class more subjects use nutritional supplements and more persons follow a dietary rule, such as a vegetarian diet can be considered to reflect a more pronounced health-conscious or riskavoidance behaviour in higher SES classes.

In our study special attention is given to consumption patterns. The present Dutch guidelines for a healthy diet are mainly based on the evidence for an association between diet and chronic disease's. especially cardiovascular disease and cancer. Compared with these guidelines, the mean intake of fat (in men and women) and cholesterol (in women only) is too high and the intake of carbohydrates and dietary fibre and the P/S ratio of the diet are too low. The amount and type of fat consumed has been identified as the main nutritional problem in the Netherlands (38). Based on total fat the low SES group may be considered to be at a higher risk since more energy is derived from fat. On the other hand, the contribution of saturated fatty acids to energy intake does not differ significantly among SES groups, whereas the $\mathrm{P} / \mathrm{S}$ ratio is even higher in the low SES class. Without the energy derived from alcohol in both men and women in the low SES class the intake of saturated fatty acids is lower (about $0.5 \mathrm{en} \%$ ) and among women differences in total fat are no longer observed. Based on these results one might even argue that the higher SES groups are at higher risk fororonary heart disease. However, as alcohol intake is higher in higher SES groups this may have a compensatory effect. 
The intakes of dietary fibre, calcium, iron, riboflavin and vitamin $\mathrm{C}$ tend to be higher in the higher SES groups. In comparison with the Dutch recommended dietary amounts (39), the highest chance for an inadequate intake is observed for pyridoxine (expressed per $g$ of protein) and iron (only in women aged 19-49). Mean iron intake is slightly lower among women with a low SES, whereas mean intake of pyridoxine per $g$ of protein is slightly lower among both men and women in the high SES class. The differences are small, however, and are not likely to indicate a higher risk of deficiencies in these groups. Since smoking increases the metabolic turnover of vitamin $\mathrm{C}$ in the body, the effect of a lower intake of vitamin $\mathrm{C}$ in the lower SES groups will most likely be enhanced by the higher prevalence of smoking in these groups. Generally, with the exception of saturated fatty acids, dietary intake in the higher SES groups tends to be closer to the dietary recommendations, although the differences are small.

Several other studies also indicate that a lower intake of vitamin C (reflecting a lower consumption of fruit and vegetables), and dietary fibre and/or bad dietary habits in general are more common in groups with a low SES and/or low educational attainment $(8,16,40)$. A higher alcohol intake is frequently observed in higher SES groups $(27,40)$. The picture is less clear for fat intake. In contrast with studies in the UK, we did not note a switch from saturated to polyunsaturated fatty acids caused by a preference for low-fat spreads and polyunsaturated margarine over butter and hard margarines in the high SES group $(41,42)$.

Previous Dutch studies have shown that subjects with a low education and/or low SES had a higher probability of a less prudent diet and a higher chance of an inadequate intake of some nutrients. In addition more of these were obese, were smokers and were less physically active (43-46). The results of our study suggest that these differences still exist.

The strength of the association between SES and dietary intake figures is likely to be weakened by the use of two-day records. Presumably, however, the average consumption data according to SES levels are unbiased estimates. Educational level, occupation and occupational position are expected to be reported accurately and thus do not systematically modify the dietary record. However, the variances associated with the estimates of average nutrient intake based on two days arc probably broader than their usual values and thus weaken the actual strength of association. Because of the absence of some other specific health-related factors such as physical activity the picture of a (un)healthy life-style is not complete.

The use of social class as an index of socio-economic position is a topic for discussion. Several studies have categorized the study population in hierarchically ordered socio-economic groups on the basis of either education or occupational status. In our study the present or previous position was also taken into account. This categorization does not match income entirely. Moreover, other factors within the social environment may influence health but are only poorly indexed by social class (i.e. wealth possession, chance of unemployment, housing quality, hours and conditions of work, expenditure on housing, heating and clothing (47)). To prevent 
underestimation of inequalities in health, Smith, Shipley \& Rose (48) advised the use of social class in conjunction with other indices of socio-economic position. Although several life-style variables and their socio-economic determinants are culture-specific these associations go roughly in the same direction across affluent societies. Therefore, in future studies more information about social environment in the Netherlands may provide a better insight into the associations with health-related life-style characteristics.

Despite these limitations, which presumably have only weakened the existing associations, our study indicates that in the Netherlands major risk factors, i.e. smoking, obesity and, to a lesser extent, a more unhealthy food consumption pattern, are more prevalent in lower SES groups. Thercfore, we conclude that subjects with a lower SES may be considered to run a higher risk of developing chronic conditions and diseases commonly observed in affluent societies.

\section{References}

1. Townsend P, Davidson N (eds). Inequalities in health: the Black Report. Harmondsworth: Penguin Books, 1982.

2. World Health Organization. The burden of social inequities. Copenhagen: WHO. 1984.

3. Blaxter M. Evidence on inequality in health from a national survey. Lancet 1987;ii: 30-33.

4. Feldman JJ. Makuc DM. Kleinman JC. Cornoni-Huntley J. National trends on educational differentials in mortality. An J Epidemiol 1989;129: 919-933.

5. Marmot MG, McDowall ME. Mortality decline and widening social inequalities. Lancet 1986;ii: 274-276.

6. Khoska T. Lowe CR. Obesity and smoking habits by social class. Br J Prev Soc Med 1972;26: 249-256.

7. Rose G, Marmot MG. Social class and coronary heart disease. Br. Heart J. 1981:45: $13=19$.

8. Fehily AM, Phillips KM, Yamell JWG. Diet, smoking, social class and body mass index in the Caerphilly Heart Disease Study. Am J Clin Nutr 1984;40: 827-833.

9. Marmot MG. Adelstein AM. Robinson N. Rose GA. Changing social-class distribution of heart disease. Br Med J 1978:2: 1109-1112.

10. Holme 1 , Helgeland A. Hjermann I, Lund-Larsen PG, Leren P. Coronary risk factors and socio-economic status - The Oslo Study. Lancet 1976:ii: 1396-1399.

11. Noppa H, Bengtsson C. Obesity in relation to socio-economic status. J Epidem Comm Health 1980:34: 139-142.

12. Baecke JAH. Burema J. Frijters JER. Hautvast JGAJ, Wiel-Wetsels WAM van der. Obesity in young Dutch adults: I Socio-demographicvariables and body mass index. Int J Obesity 1983;7: 1-12.

13. Duijkers TJ, Kromhout D, Spruit IP. Doornbos G. Inter-mediating risk factors in the relation between socio-economic status and 25 -year mortality (the Zutphen Study). Int J Epidemiol 1989;18: 658--662.

14. Cronin FJ. Krebs-Smith SM. Wyse BM. Characterizing food usage by demographic variables. J Am Diet Assoc 1982:81: 661-673.

15. Windham CT, Wyse BW, Hansen RG. Hurst RL. Nutrient density of dicts in the USDA Nationwide Food Consumption Survey 1977-1978: I Impact of socioeconomic status on dietary density. J Am Diet Assoc 1983:82: 28-34. 
16. Aro S, Räsänen L. Telama R. Social class and changes in health-related habits in Finland in 1973-1983. Scand J Soc Med 1986;14:39-47.

17. Prättälä R. Socio-demographic differences in fat and sugar consumption patterns among Finnish adolescents. Ecol Food Nutr 1988;22: 53-64.

18. Anonymous. The Dietary and Nutritional Survey of British Adults. Office of Population. Censuses and Surveys for the Ministery of Agriculture. Fisheries and Food and the Department of Health. London: HSMO, 1990.

19. Löwik MRH, Hermus RJJ. The Dutch nutrition surveillance system. Food Policy 1988:13: 359-365.

20. Hulshof KFAM, Staveren WA van. The Dutch National Food Consumption Survey: design. methods and first results. Food Policy 1991:16: 257-260.

21. NEVO-tabel. Nederlands Voedingsstoffenbestand 1986-1987. The Hague: Voorlichtingsbureau voor de Voeding, 1987.

22. Dillon WR. Goldstein M. Multivariate analysis; methods and applications. New York: J Wiley \& Sons 1984;302-337.

23. Wingard DL. Berkman LF, Brand RJ. A multivariate analysis of health-related practices. Am J Epidem 1982:116: 765-775.

24. Baecke JAH, Burema J, Frijters JER, Hautvast JGAJ. Wiel-Wetzels WAM van der. Obesity in young Dutch adults. II Daily lifestyle and body mass index. Int J Obesity 1983:7: 13-24.

25. Axelson, ML. The impact of culture on food-related behavior. Ann Rev Nutr 1986:6: 345-363.

26. Lubben JE. Weiler PG.Chi I. Health practices of the elderly poor. Am J Public Health 1989:79: 731-734.

27. Shaw M, Jeffry RW. Hannan PJ. Onstod L. Relationship betweensocio-demographic and behaviour variables. and body mass index in a population with high-normal blood pressure: hypertension prevention trial. Eur J Clin Nutr 1989:43: $583--596$.

28. Solvoll K. Selmer R. Løken EB. Foss OP. Trygg K. Coffec, dictary habits, and serum cholesterol among men and women 35-49 years of age. Am J Epidemiol 1989;129: $1277-1288$.

29. Garrow JS. Treat obesity seriously. A clinical manual. Edinburgh: Churchili Livingstonc. 1981.

30. Dixun WJ. Brown MB. Engelman L. Jenrich RI. BMDP Statistical Software Manual. Berkeley: University of Calilornia Press. 1990.

31. Sicgdl S. Nonparametric statistics. New York: Mc Crawn Hill, 1956.

32. Surgeon General. Report on Nutrition and Health. U.S. Department of Health and Human Services. Washington DC: Public Health Service. DHHS (PHS) Publication No. 88-502010, 1988.

33. Birkbeck JA. Obesity, socioeconomic variables and eating habits in New Zealand. J Biosoc Sci 198 1:13: 299-307.

34. Hegsted DM. Ausman LM. Diet. alcohol and coronary heart disease in men. J Nutr 1988:118:1184-1189.

35. Cummings RO, Shuper AG, Walker $M$, Wale $C J$. Smoking and drinking by middleaged British men: effects of social class and town of residence. Br Med J 1981:283: $1497-1502$.

36. Jacobsen BK. Thelle DS. The Tromso Heart Study: food habits, serum total cholesterol, HDL Cholesterol, and triglycerides. Am J Epidemiol 1987:125: 622-630.

37. Puccio FM, McPhillips JB. Barrett-Connor E, Ganiats TG. Clustering of atherogenic behaviors in coffec drinkers. Am J Public Health 1990:80: 1310-1313.

38. Netherlands Nutrition Council. Guidelines for a healthy diet. The Hague: Recommendations drawn up by the Committee on Guidelines for a healthy diet. 1986.

39. Netherlands. Nutrition Council. Recommended dietary allowances in the Netherlands. The Hague, 1990. 
40. Braddon FEM, MEJ Wadsworth, JMC Davies, HA Crips. Social and regional differences in food and alcohol consumption and their measurement in a national birth cohort. J Epidemiol Comm Health 1988;42: 341-349.

41. Wichelow MJ. Choice of spread by a random sample of the British population. Eur $J$ Clin Nutr 1989;43: 1-10.

42. Bolton-Smith C, Smith WCM, Woodward M, Brown CA, Tunstall-Pedoe H. Dittiry differences between social class groups in the Scottish Heart Health Study. Proc Nutr Soc 1990:49: 62A.

43. Kok FJ, Matroos AW, Ban AW van den. Hautvast JGAJ. Characteristics of individuals with multiple behavioral risk factors for coronary heart disease in The Netherlands. Am J Public Health 1982;72: 986-991.

44. Hulshof KFAM, Wedel M, Ockhuizen Th. Dietary intake, lifestyle and anthropometry of 18-year old men in The Netherlands. Nutr Rep Int. 1988;37: 755-765.

45. Löwik MRH, Westenbrink S, Wedel M. Schrijver J. De invloed van sociaal economische factoren op de voeding en voedingstoestand van ouderen. Voeding 1989;50: 38-42.

46. Westenbrink S, Löwik MRH. Hulshof KFAM. Kistemaker C. Effect of household size on nutritional patterns among Dutch elderly. J Am Diet Assoc 1989;89: 783-799.

47. Reid I. Social class differences in Britain: life-chances and life-styles. Glasgow: Fontana Press, 1989.

48. Smith GD, Shipley MJ, Rose G. Magniturte and causes of socioeconomic differentials in mortality: further evidence from Whitehall Study. J Epidemiol Comm Health 1990:44: $265-270$. 


\title{
Clustering of dietary variables and other life-style factors (Dutch Nutrition Surveillance System)
}

\author{
K.F A.M. Hulshof, M.Wedel, M.R.H. Löwik, F.J. Kok, C. Kistemaker, R.J.J. Hermus, \\ F. ten Hoor, Th. Ockhuizen
}

\section{Abstract}

The aim of this study was to investigate whether dietary factors cluster in a favourable or unfavourable way and to characterize the groups identified by life-style and sociodemographic variables. This cross-sectional study was based on data of the 1987-1988 Dutch National Food Consumption Survey (DNFCS), obtained from a panel by a stratified probability sample of the non-institutionalized Dutch population. In total, 3781 adults (1802 males and 1979 females) of the DNFCS, aged 19 to 85 , were studied.

To estimate dietary intake two-day food records were used. Life-style data were collected by structured questionnaire and sociodemographic variables were available from panel information. Cluster analysis was used to classify subjects into groups based on similarities in dietary variables. Subsequently, these groups were characterized by sociodemographic and life-style factors as well as by the consumption of food groups. Eight clusters were found. In comparison with the guidelines, the dietary quality in four clusters was poor. The cluster with the poorest dietary pattern (high intake of fat, cholesterol and alcohol, low intake of dietary fibre) showed on the average a high consumption of animal products (except milk), fats and oils, snacks and alcoholic beverages and a low consumption of fruit, potatoes, vegetables and sugar-rich products. Smoking, body mass index, dietary regimen on own initiative, hours of sleep, gender, age, socio-economic status and day of the week were found to discriminate among the clusters.

Cluster analysis resulted in substantial differences in mean nutrient intake and scems useful for dietary risk group identification. Undesirable life-style habits were interrelated in some clusters, but an exclusive life-style for health risk was not found. 


\section{Introduction}

Life-style patterns contribute to morbidity and mortality in affluent societies. Although life-style variables, such as smoking, independently affect health status, interdependences among these factors are frequently observed. A combination of life-style practices may introduce a health risk that is greater than would be expected from the sum of the individual factors (1-4). Among adult males a relatively high consumption of coffee and alcohol, smoking and few hours of sleep per night are all positively associated with body mass index (BMI) (5). Prevalences of cardiovascular and other health-related risk factors are often highest in lower socio-economic strata in affluent societies (6-9). In the Netherlands, sociodemographic factors are found to be associated with diet and other health-related variables (smoking, obesity, physical inactivity) (10-12). Combinations of cardiovascular risk factors are more frequently obscrved among elderly people with a lower socio-economic status (SES), whereas the associations between SES and the separate risk factors are less consistent (13). Furthermore, differences in mean food consumption among Dutch population groups are relatively small. For instance, adults have a mean fat intake accounting for about $40 \%$ of total energy intake ( 40 en\%), whereas the differences between high and low socio-economic groups are about 1.5 en\% (14).

Classifying people according to their consumption pattern by simultaneously considering the total diet may provide larger differences among groups based on nutrient profiles. The purpose of our study was thus to investigate whether dietary factors cluster in a favourable or unfavourable way and whether the groups identified could be characterized by life-style and sociodemographic variables. Subsequently, the consumption of food (groups) was studied to provide insight into the origin of the differences among clusters.

\section{Methods}

\section{Study population and data collection}

In 1987-1988, the first Dutch national food consumption survey (DNFCS) was carried out. The data were obtained from a probability sample of the noninstitutionalized Dutch population aged 1 to $85(n=5898$, response rate $81 \%)$. The methods regarding sampling procedures and dietary data collection are described in detail elsewhere (15). Briefly, to assess dietary intake two-day estimated records were used. In each household the person principally responsible for domestic affairs was the most important informant and was visited on two occasions by a specially trained dietitian. During the first visit the household diary was explained. In this diary all the food supplied by the main housekeeper to the members of the household was recorded. Precise description of methods of cooking. recipes and ingredients were requested. The housekeeper also noted for each meal the persons attending and the type and quantities of food items served to them, as well as the 
amounts of leftovers and food given to pets. In addition, a diary was kept by each person to record food eaten out. During the second visit the interviewers checked the diary for completeness. Common household measures and food regularly used were weighed. In the present study people under 19 were excluded because food consumption patterns for children and adolescents differ from those for adults.

Pregnant women $(n=52)$ and subjects with a diet prescribed by a physician $(n=353)$ were excluded because these conditions are likely to affect food selection and hence nutrient intake. The population remaining for statistical analyses included 3781 adults ( 1802 men and 1979 women).

For each individual the average intake of foods and nutrients over two (consecutive) days was calculated. Nutritional supplements were not included in the calculations of nutrient intakes. Intake of protein, fat, carbohydrate and alcohol was calculated as percentage of total energy intake (en\%) and the intake of other nutrients was expressed per MJ. In total, 883 different food items (codes corresponding with the extended computerized version of the Dutch food composition table (16)) were used by the respondents. The costs of these products were estimated using data obtained from the Netherlands Central Bureau of Statistics $(17,18)$. In case of missing data, information on costs was obtained from large supermarkets and from a marketing research institute. Food items were combined into 26 food groups classified on the basis of similarity in nutrient composition and/or origin.

In addition to information on food consumption, data were collected on the respondent's body weight and standing height (both self-reported values), use of nutritional supplements, special dietary practices, smoking habits, meal pattern and hours of sleep on the two consecutive days, by means of structured questionnaires. Information about education, occupation, SES and demographic variables were obtained from the marketing research institute which carried out the field work (AGB-Attwood).

\section{Statistics}

K-means cluster analysis (19) was used to classify individuals into a limited number of groups on the basis of similarity in nutrient intake. The criteria (dimensions) chosen to classify subjects were the consumption of fat (en\%), P/S ratio (polyunsaturated fatty acids/saturated fatty acids), dietary fibre ( $\mathrm{g} / \mathrm{MJ})$, cholesterol (mg/MJ), monosaccharides and disaccharides (en\%), and alcohol (g). These variables are considered to have a potential impact on the health of the population in general, and for all these variables dietary guidelines have been formulated (20). To restrict the influence of alcohol on the other variables (all related to energy) used in the clustering, the calculation of energy was exclusive of the energy derived from alcohol.

The K-means cluster procedure of the BMDP statistical package (program KM (21)) was used to construct the clusters. Because of differences in scale, the variables 
were standardized before clustering. The $\mathrm{K}$-means cluster procedure requires that the number of clusters is specified before the analysis. As the actual number of clusters present in the data was unknown, the selection of the best number of clusters was based on a so-called scree-plot, in which the variance that remained within the clusters is portrayed against the number of clusters (varying from 2 to 10 clusters). When the plot levels off, no additional reduction of the within-cluster variance is achieved. The number of clusters corresponding with this point was selected as the most appropriate fit to the data.

To obtain an impression of the nutritional quality of the diets of the identified clusters a scoring system based on the Dutch Dietary Guidelines (20) was developed. For each dietary variable a score of 1 was attached to an intake most deviant from the recommendations, whereas a score of 5 was given to an intake level considered to be most desirable (Table 6.1). Thereafter, a weighted sum of the scores for the different criteria was calculated for each cluster. This weighting was introduced since differences in potential impact on health exist. Actually, the highest weight (10) was given to fat; $\mathrm{P} / \mathrm{S}$ ratio and dietary fibre were assigned a weight of 3 , cholesterol a weight of 2 , and monosaccharides and disaccharides as well as alcohol a weight of 1. In this way a sum score was obtained ranging potentially from 20 (indicating a diet of poor quality) to 100 (indicating a prudent diet). Although the weighing system developed is rather subjective, the system does not affect the results obtained and is used only as an aid in interpreting the results. A further motivation of the system and its robustness to changes in the subjective weights is provided in the Discussion section.

The clusters found were characterized by sociodemographic and health-related life-style factors (3-5, 22-25), as well as by the consumption of food groups. Available variables were: smoking, obesity, breakfast habits, special dietary habits, use of nutritional supplements, alcohol consumption, coffee consumption and hours of sleep. A (step-wise) discriminant analysis was performed to study whether these variables differed for the various clusters. The type of day (two week days, two weekend days or one week and one weekend day) was incorporated in this analysis, because the distribution of the food record days may differ among clusters and could therefore influence average nutrient intake for the clusters. A second analysis was

Table 6. 1 . The scoring system used to evaluate the nutritional quality of the diet in each cluster.

\begin{tabular}{|c|c|c|c|c|c|c|}
\hline \multirow[t]{2}{*}{ Cluster variable } & \multicolumn{6}{|l|}{ Score } \\
\hline & 1 & 2 & 3 & 4 & 5 & weight \\
\hline Fat $(e n \%)^{1}$ & $\geq 45$ & $40-45$ & $35-40$ & $30--35$ & $<30$ & 10 \\
\hline $\mathrm{P} / \mathrm{S}$ ratio & $<0.35$ & $0.35-0.40$ & $0.40-0.45$ & $0.45-0.50$ & $\geq 0.50$ & 3 \\
\hline Dictary fibre (g/MJ) & $\leq 1.8$ & $1.9-2.3$ & $2.3-2.6$ & $2.6-3.0$ & $\geq 3.0$ & 3 \\
\hline Cholesterol (mg/MJ) & $\geq 44$ & $38-44$ & $33-38$ & $26-33$ & $<26$ & 2 \\
\hline MD' $(\mathrm{en} \%)$ & $\geq 30$ & $26-30$ & $22-26$ & $18-22$ & $<18$ & 1 \\
\hline Alcohol (g/day) & $>40$ & $31-40$ & $21-30$ & $11-20$ & $\leq 10$ & 1 \\
\hline
\end{tabular}

1 en\%. To total encrgy intake: MD. mono-and disaccharides. 
performed to find combinations of food group consumption that best discriminated among the clusters. The computed standardized discriminant function coefficients were used to indicate the relative importance of the variables for the discrimination among the clusters.

One of the drawbacks of a cluster analysis is the possible dependence of the results on the sample selected and the methodology used for dietary assessment. Other clusters may be found when another sample is used. Therefore we established the stability of the cluster solution across independent samples. A clustering procedure identical to the procedure described above was performed on an independent sample of 395 subjects aged $65-80$, for whom the habitual intake of the selected nutrients was estimated by means of a dietary history with cross-check (26). The average values of the criteria found in the clusters identified in the present study were used as initial cluster centres for this analysis. The correspondence of the cluster solutions was calculated for each cluster using correlation coefficients, after standardizing the variables.

\section{Results}

\section{General discription of the population}

For both men and women the mean age was approximately 42 years. Almost half of the population belonged to the stratum with a low SES and $10 \%$ to the highest stratum. About $20 \%$ of the men and $13 \%$ of the women had a higher professional or university education. About $16 \%$ of the women and $6 \%$ of the men were living alone; $15 \%$ vs. $9 \%$ used nutritional supplements and 9 vs. $3 \%$ followed a dietary rule (e.g. vegetarianism) or dietary regimen on their own initiative; $47 \%$ of the men and $38 \%$ of the women were smokers. About $66 \%$ of the men and $44 \%$ of the women reported having consumed alcohol during the two-day record period. In general, men were taller and heavier than women and had a higher body mass index (BMI 24.4 vs. $23.7 \mathrm{~kg} / \mathrm{m}^{2}$ ).

\section{Cluster analysis}

Eight clusters were identified as the most adequate representation of the structure of dietary intake combinations in the data. Table 6.2 lists the mean values of the six criteria in the eight clusters, ranked by fat intake. In five clusters the mean contribution of fat to energy intake exceeded $40 \%$. In clusters 1 and 2 , representing $25 \%$ of the sample, mean fat intake was close to $50 \mathrm{en} \%$. In two clusters the high fat intake was accompanied with a high alcohol consumption and a low intake of monosaccharides and disaccharides (clusters 2 and 4). The lowest mean fat intake ( $32.5 \mathrm{en} \%$ ), combined with the highest monosaccharide and disaccharide consumption ( 33.8 en\%) was observed in cluster 8 . Only one cluster (cluster 3 ) had a mean $\mathrm{P} / \mathrm{S}$ ratio $>0.50$; this value was accompanied with a relatively high fat intake. 
Table 6.2. Daily intake (mean and SD) of dietary variables' and indication of nutritional adequacy according to eight clusters.

\begin{tabular}{|c|c|c|c|c|c|c|c|c|}
\hline Dietary variable & $\begin{array}{l}1 \\
(n=461)\end{array}$ & $\begin{array}{l}2 \\
(n=517)\end{array}$ & $\begin{array}{l}3 \\
(n=425)\end{array}$ & $\begin{array}{l}4 \\
(n=550)\end{array}$ & $\begin{array}{l}5 \\
(n=515)\end{array}$ & $\begin{array}{l}6 \\
(n=557)\end{array}$ & $\begin{array}{l}7 \\
(n=490)\end{array}$ & $\begin{array}{l}8 \\
(n=2(.8)\end{array}$ \\
\hline Fat $(e n \%)^{2}$ & $48.9(5.3)$ & $48.4(4.9)$ & $44.8(5.2)$ & $44.4(4.5)$ & $42.5(4.1)$ & $39.1(4.1)$ & $35.9(5.1)$ & $32.5(5.6)$ \\
\hline P/S ratio & $0.37(0.13)$ & $0.44(0.16)$ & $0.77(0.21)$ & $0.34(0.13)$ & $0.36(0.13)$ & $0.42(0.14)$ & $0.36(0.14)$ & $0.41(0.16)$ \\
\hline Dietary fibre (g/MJ) & $2.6(0.7)$ & $1.8(0.4)$ & $2.7(0.7)$ & $3.0(0.6)$ & $2.0(0.4)$ & $2.3(0.6)$ & $3.7(1.0)$ & $2.4(0.8)$ \\
\hline Cholesterol $(\mathrm{mg} / \mathrm{MJ})$ & $40(15)$ & $44(14)$ & $26(10)$ & $38(12)$ & $36(11)$ & $28(9)$ & $31(11)$ & $23(8)$ \\
\hline $\mathrm{MD}^{2}(\mathrm{en} \%)$ & $14.6(4.0)$ & $16.4(4.4)$ & $19.6(4.8)$ & $17.4(4.0)$ & $24.3(3.8)$ & $24.6(4.1)$ & $23.4(4.7)$ & $33.8(4.9)$ \\
\hline Alcohol (g) & $0.3(1)$ & $35(23)$ & $7(13)$ & $25(18)$ & $0.6(2)$ & $31(22)$ & $2(5)$ & $7(15)$ \\
\hline Sum score ${ }^{3}$ & 42 & 31 & 64 & 50 & 46 & 61 & 67 & 74 \\
\hline
\end{tabular}

1 Calculated without the energy derived from alcohol.

${ }^{2}$ en\%, percentage of total energy intake; MD, mono- and disaccharides.

${ }^{3}$ Sum score has a minimum value of 20 points and a maximum of 100 points (see Table 6.1). 
In comparison with the guidelines, the dietary quality of clusters 1, 2, 4 and 5 was moderate or poor, as indicated by the sum scores of 50 or lower. The average dietary characteristics among members of clusters $3,6,7$ and 8 were more in accord with the recommendations, scores being 60 or higher. The highest energy intake was observed in clusters $2(11.6 \mathrm{MJ} /$ day) and 6 (11.3 MJ/day), whereas clusters 1 and 7 had the lowest intake ( 9.0 and $8.2 \mathrm{MJ} /$ day, respectively). Subjects in cluster 7 used diets with the highest mean mineral and vitamin density, whereas in cluster 2 the lowest density was observed (results not shown).

\section{Discriminant analysis}

Variables with standardized discriminant function coefficients greater than 0.35 (or less than-0.35) for at least one of the canonical variables are presented in Tables 6.3 and 6.4. For each of the analyses, three canonical variables had a clear interpretation and explained about $90 \%$ of the variance in the predictor variables. The standardized discriminant function coefficients in the first analysis suggest that gender, smoking and week days were most predictive for the first canonical variable which explained

Table 6.3. Standardized discriminant function coefficients and cluster means for canonical variables related to sociodemographic and life-style characteristics.

\begin{tabular}{|c|c|c|c|}
\hline \multirow[t]{2}{*}{ Characteristic } & \multicolumn{3}{|c|}{ Canonical variable 1} \\
\hline & 1 & 2 & 3 \\
\hline Age (years) & 0.02 & 0.25 & 0.56 \\
\hline Body mass index $\left(\mathrm{kg} / \mathrm{m}^{2}\right)$ & 0.08 & -0.49 & 0.51 \\
\hline Gender, female & 0.61 & -0.56 & 0.01 \\
\hline Socio-economic status, low & 0.11 & -0.42 & -0.28 \\
\hline Smoking & -0.42 & -0.31 & 0.11 \\
\hline Sleeping time, $<7 \mathrm{~h}$ & -0.27 & -0.11 & 0.43 \\
\hline Week day & 0.79 & 0.25 & 0.79 \\
\hline One week day and one weekend day & 0.35 & 0.04 & 0.33 \\
\hline Dietary rule/regimen on own inititative & 0.18 & 0.50 & 0.07 \\
\hline \multicolumn{4}{|l|}{ Cluster means ${ }^{2}$} \\
\hline Cluster 1 & 0.42 & -0.32 & 0.11 \\
\hline Cluster 2 & -0.55 & -0.10 & 0.15 \\
\hline Cluster 3 & 0.11 & 0.15 & -0.11 \\
\hline Cluster 4 & -0.06 & 0.14 & 0.30 \\
\hline Cluster 5 & 0.12 & -0.23 & -0.17 \\
\hline Cluster 6 & -0.51 & 0.09 & -0.17 \\
\hline Cluster 7 & 0.59 & 0.23 & 0.01 \\
\hline Cluster 8 & 0.05 & 0.06 & -0.30 \\
\hline
\end{tabular}

1 The canonical variables constitute linear combinations of the characteristics that best discriminate between the clusters.

${ }^{2}$ Means of canonical variables for each cluster; only the relative magnitude of the means among the clusters can be interpreted. 
$64 \%$ of the variance of the sociodemographic and life-style characteristics. The cluster means of the discriminant scores show that the first variable predominantly discriminated clusters 1 and 7 from clusters 2 and 6. BMI, gender, low SES, and dictary regimen were strongly associated with the second canonical variable which explained another $13 \%$ of the variance and discriminated clusters 1 and 5 from clustur 7. Age, BMI, hours of sleep and week days were most important for the third canonical variable, which explained $14 \%$ of the variance and discriminated between clusters 4 and 8 . Region, urbanization level, education, household size, missing breakfast during the survey, and use of supplements hardly discriminated among the clusters, all having low standardized discriminant function scores.

In the second stepwise discriminant analysis the consumption of 26 food groups was used to explain cluster differences. The results indicated that $51 \%$ of the variance in the food groups was explained by the first canonical variable. Sugar-rich products, fats and oils, high-fat meat, soft drinks, eggs, cheese and fruit were most predictive for this variable, which discriminated clusters 1 and 2 from clusters 7 and 8 (Table 6.4). The second canonical variable, with sugar-rich products and alcoholic beverages, explained $26 \%$ of the total variance and discriminated clusters 2,6 and 8 from clusters 1 and 7 . The third canonical variable, with bread, fats and oils and alcoholic beverages as most predictive variables, explained $14 \%$ of the variance and discriminated between clusters 5 and clusters 4,6 and 7 .

Table 6.4. Standardized discriminant function coefficients and cluster means for canonical variables related to intake of food groups

\begin{tabular}{|c|c|c|c|}
\hline \multirow[t]{2}{*}{ Food group } & \multicolumn{3}{|c|}{ Canonical variable ${ }^{1}$} \\
\hline & 1 & 2 & 3 \\
\hline Fruits & 0.36 & 0.11 & 0.26 \\
\hline Bread & 0.14 & 0.27 & 0.44 \\
\hline Cheese & -0.37 & -0.03 & -0.07 \\
\hline Eggs & -0.39 & -0.01 & -0.20 \\
\hline Fats and oils & -0.51 & -0.05 & -0.44 \\
\hline Sugai (products) & 0.72 & -0.55 & -0.18 \\
\hline Alcoholic beverages & -0.12 & -0.73 & 0.67 \\
\hline Meat/poultry fat & -0.50 & -0.07 & -0.24 \\
\hline Soft drinks & 0.46 & -0.30 & -0.21 \\
\hline \multicolumn{4}{|l|}{ Cluster me'ans:- } \\
\hline Cluster 1 & -0.80 & 0.95 & -0.44 \\
\hline Cluster 2 & -1.78 & -0.79 & -0.08 \\
\hline Cluster 3 & 0.10 & 0.49 & -0.19 \\
\hline Cluster 4 & -0.57 & 0.35 & 0.63 \\
\hline Cluster 5 & 0.41 & -0.19 & -1.00 \\
\hline Cluster 6 & 0.40 & -1.07 & 0.57 \\
\hline Cluster 7 & 1.02 & 0.96 & 0.54 \\
\hline Cluster 8 & 2.32 & -0.78 & 0.35 \\
\hline
\end{tabular}

${ }^{12}$ See table 6.3 


\section{Cluster characteristics}

A more detailed description of the characteristics of clusters 1, 2, and 7 will be presented, as these clusters constitute the most relevant differences in food intake, sociodemographic and life-style variables (see Discriminant analysis). Based on two of the cluster criteria the clusters are called high fat/low alcohol (HFLA, cluster 1), moderate fat/low alcohol (MFLA, cluster 7) and high fat/high alcohol (HFHA, cluster 2).

Table 6.5. Sociodemographic and life-style characteristics . «cording to cluster. ${ }^{1}$

\begin{tabular}{|c|c|c|c|c|}
\hline Cluster & $\begin{array}{l}\text { HFLA } \\
(n=461)\end{array}$ & $\begin{array}{l}\text { MFLA } \\
(n=490)\end{array}$ & $\begin{array}{l}\text { HFHA } \\
(n=517)\end{array}$ & $\begin{array}{l}\text { All } \\
(n=3781)\end{array}$ \\
\hline Proportion of women (\%) & 69 & 67 & 39 & 52 \\
\hline Age (years) & 42.8 & 42.6 & 41.9 & 41.6 \\
\hline \multicolumn{5}{|l|}{ Age group (\%) } \\
\hline $19-24$ & 10 & 11 & 8 & 11 \\
\hline $25-49$ & 58 & 56 & 64 & 60 \\
\hline $50-64$ & 22 & 22 & 19 & 19 \\
\hline$\geq 65$ & 10 & 11 & 9 & 10 \\
\hline \multicolumn{5}{|l|}{ SES $(\%)$} \\
\hline low & 57 & 41 & 45 & 47 \\
\hline high & 7 & 13 & 10 & 10 \\
\hline \multicolumn{5}{|l|}{ Education (\%) } \\
\hline low & 49 & 35 & 40 & 40 \\
\hline high & 8 & 20 & 16 & 16 \\
\hline \multicolumn{5}{|l|}{ Body mass index (\%) } \\
\hline $25.0-29.9 \mathrm{~kg} / \mathrm{m}^{2}$ (obese) & 28 & 31 & 26 & 27 \\
\hline$\geq 30 \mathrm{~kg} / \mathrm{m}^{2}$ (severely obese) & 10 & 6 & 5 & 5 \\
\hline Smoking (\%) & 39 & 24 & 54 & 42 \\
\hline Dietary regimen (\%) & 5 & 13 & 4 & 6 \\
\hline \multicolumn{5}{|l|}{ Type of surveyed days (\%) } \\
\hline 2 week days & 69 & 71 & 41 & 59 \\
\hline 2 weekend days & 8 & 7 & 23 & 14 \\
\hline 1 week day and 1 weekend day & 23 & 21 & 36 & 27 \\
\hline \multicolumn{5}{|l|}{ Night's rest $(\%)$} \\
\hline$<7 \mathrm{~h}$ & 9 & 4 & 16 & 10 \\
\hline $7-8 h$ & 43 & 47 & 36 & 43 \\
\hline$\geq 9 \mathrm{~h}$ & 48 & 48 & 48 & 47 \\
\hline \multicolumn{5}{|l|}{ Use of breakfast (\%) } \\
\hline both days & 85 & 90 & 73 & 82 \\
\hline 1 day & 6 & 5 & 13 & 9 \\
\hline 0 days & 9 & 5 & 13 & 9 \\
\hline Usage of nutritional supplements (\%) & 12 & 16 & 8 & 12 \\
\hline Living alone $(\%)$ & 10 & 14 & 8 & 11 \\
\hline
\end{tabular}

1 HFLA. high fat/low alcohol; MFLA, moderate fat/low alcohol; HFHA, high fat/high alcohol; SES, socioeconomic status. 

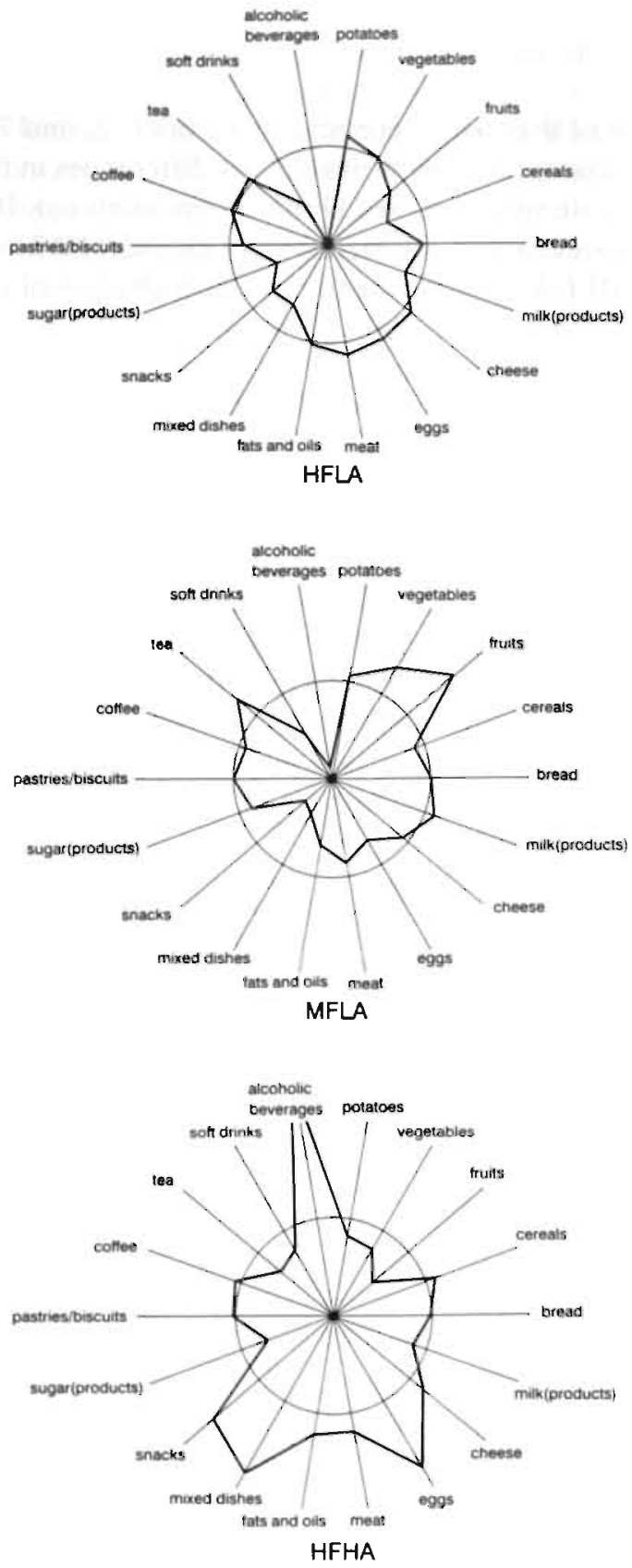

Fig. 6.1. Mean daily consumption of various food groups by cluster expressed as the deviation (\%) from the overall consumption, the circle corresponding with the average consumption of the total population. HFI.A, high fat/low alcohol cluster; MFLA, medium fat/low alcohol cluster: HTHA. high fat/high alcohol cluster. 
Table 6.5 summarizes the sociodemographic and life-style characteristics that differ significantly among the clusters $\left(\chi^{2}\right.$ test). The HFLA cluster contained a higher proportion of women, more subjects with low SES, more subjects with (severe) obesity and an overrepresentation of week days. The MFLA cluster comprised more participants with high SES, more with a dietary regimen on their own initiative, more women, fewer smokers and fewer subjects with less than $7 \mathrm{~h}$ sleep. This cluster also contained a higher proportion of subjects that had reported dietary intake during week days. The HFHA cluster was made up of a higher proportion of men, more middle-aged participants, more smokers, more subjects with less than $7 \mathrm{~h}$ sleep and a higher proportion of subjects that reported dietary intake on one or two weckend days.

\section{Food consumption pattern}

Figure 6.1 presents the deviation (in \%) from the overall mean consumption of relevant food groups per cluster. The HFLA cluster consisted of subjects with a somewhat higher mean consumption of potatoes and animal products (especially high-fat meat), whereas the intake of products mainly consumed between the meals (snacks, sugar-rich products, soft drinks and alcoholic beverages), mixed dishes and milk (products) was low. Members of the MFLA cluster consumed more potatoes, vegetables and fruits, more (low-fat) milk (products) and tea than the average population, whereas the consumption of all other food items, bread and pastry excepted, was (much) lower. The HFHA cluster had a high intake of animal products (except milk), fats and oils, savoury snacks, mixed dishes, and alcohol (almost half of the cluster members had used more than six glasses of alcoholic beverages during the two days). This intake pattern was accompanied with a (very) low consumption of fruit, potatoes, vegetables, sugar-rich products, and tea.

\section{Costs of food}

Figure 6.2 shows the average daily costs according to cluster and the contribution of different food groups to these costs. Including alcohol, the mean daily costs for foods and drinks ranged from NLG (Dutch guilders) 7.06 (HFLA) to NLG 10.28 (HFHA). In all clusters the group 'meat and poultry' was the most important contributor to dietary costs $(22-31 \%)$. In the three clusters with a high alcohol consumption, alcoholic beverages were responsible for 19 to $22 \%$ of the costs. Other important contributors were vegetables, milk (products), cheese and non-alcoholic beverages such as soft drinks and coffee. When the costs of alcoholic beverages were excluded from the calculations the food patterns of subjects in the HFHA cluster remained the most expensive. However, when the daily costs were related to energy 

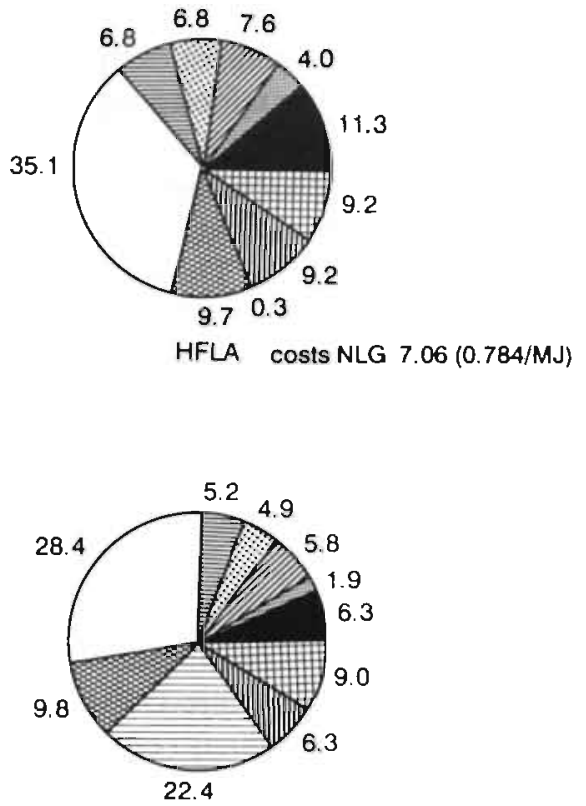

HFHA costs NLG $10.28(0.886 / \mathrm{MJ})$

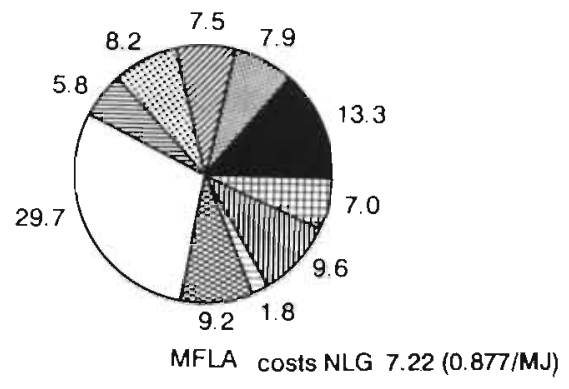

Legend

vegetables/potatoes;

fruits:

bread/cereals:

milk (products)

cheese:

mea:/poultry/fish/eggs;

savoury snacks;

alcoholic beverages:

other beverages:

other products.

Fig. 6.2. Average daily costs of diets: contribution (\%) of food groups to costs.

intake the picture changed somewhat: the average costs per MJ in the MFLA cluster approached those for the HFHA cluster.

\section{Stability of cluster solutions}

The results of the validation study revealed that the overall agreement between cluster profiles was reasonable ( $r=0.62$ on average). The most marked differences were observed for cholesterol intake and $\mathrm{P} / \mathrm{S}$ ratio, especially in clusters 1 and 3 . In these two clusters the correspondence between the average cluster criteria based on the DNFCS and the validation results was low (both $r=-0.21$ ). In the other clusters the correlation coefficients varied from 0.71 (cluster 4 ) to 0.96 (cluster 7 ). When the cluster means were calculated for subjects aged 65 or over in the DNFCS the agreement between the cluster solutions hardly differed. 


\section{Discussion}

In this study we used cluster analysis in an attempt to classify individuals on the basis of their nutrient intake into rather homogeneous groups. As compared to the more traditional approach of a priori selection of groups (e.g. socio-economic groups), followed by analysis of variance, cluster analysis examines more dynamically patterns of intake of (selected) nutrients by grouping subjects with comparable combinations of intake levels. Cluster analysis or factor analysis based on the individual consumption of foodstuffs is used to identify eating patterns (27-32). However it is not the presence or absence of separate food items but rather the appropriate selection (proper amounts and combinations) of foods that is important to health. Therefore, we grouped respondents on the basis of dietary factors for which guidelines have been formulated.

Smoking, BMI, dietary regimen, hours of sleep, gender, age, SES and type of surveyed day were found to discriminate among the clusters. A priori segmentation by SES, age and gender separately did show some differences in dietary intake, but they were small (14). In this study differences in mean levels found among clusters were much larger and combinations of (un)desirable factors were observed. For example, the HFHA cluster contained a higher proportion of smokers and more people that slept less than $7 \mathrm{~h}$ per night than the overall population. Thus cluster analysis based on dietary characteristics is a promising method for risk group identification. However, on the basis of a limited number of life-style variables and traditional sociodemographic factors, we could not find an exclusive life-style for specific groups of the population. Further study is warranted to determine whether there are indices of life-style and or sociodemographic characteristics which are more sensitive and therefore could provide a better segmentation of the population.

As the possible instability of the results could be one of the limitations of a cluster analysis, we studied the validity of the cluster solution in another sample. This sample was made up of subjects aged 65-80 and figures for the usual dietary intake were available. The overall correspondence between average values of the clustering criteria within clusters was satisfactory. Future studies should provide further evidence of the stability of the results of the present study.

As in other studies, gender as well as day of the week influence food consumption $(30,31,33)$. Instead of performing cluster analyses separately for males and females and for week days and weekend days we used both factors in discriminant analysis. In this way we avoided an increase in the number of clusters and a decrease in the size of these clusters which would have led to complex results that are less stable and more difficult to interpret. Gender and type of day were not always associated with differences in (un)desirable life-style variables found among clusters. For instance, the HFLA and the MFLA cluster differed substantially in intake levels but not in gender or percentage of week days. A high alcohol consumption in the different clusters was associated with weekend days as well as with week days (the latter results are not presented). The differences among the 
clusters regarding day of the week represented may have important implications for the interpretation of the results. The clusters found may partly be the result of somewhat 'unhealthier' food habits during the weekends. Since the day of the week was hardly associated with the second canonical variable that discriminated between the HFLA and MFLA, clusters were not solely the result of type of day. Moreover, the results obtained from the dietary intake figures in the second sample reflecting habitual food consumption were in line with the results based on two-day records.

The nutritional health of the average diets of the various clusters was evaluated with the aid of a scoring system. In this system criteria of a prudent diet were used as a standard (20.34). In the Netherlands, a high fat intake is currently considered to be the main nutritional problem and discouragement of a high fat intake is generally accepted to be of prime importance. Therefore the fat score was given the highest weight (10 points). An excessive alcohol consumption constitutes a serious health risk and is discouraged. Therefore, alcohol consumption could receive a relatively high weight in the system. However, the sample we used was not likely to include individuals with excessive alcohol intake (15). Although some health risks of moderate alcohol consumption have been identified, beneficial effects have also been reported (35) and alcohol was thus given a weight of 1 point. Of course, the introduction of weights is somewhat subjective. However, when fat was given the weight of 10 points and all the other criteria were given 3 points, the ranking of the clusters based on their sum scores was identical to that presented in Table 6.3. This was also the case when we used the intake of saturated fatty acids (en\%) instead of the $\mathrm{P} / \mathrm{S}$ ratio. In a recent update of the guidelines for a healthy diet in 1991 , the Netherlands Nutrition Council recommends that saturated fatty acids should not exceed $10 \mathrm{en} \%$, whereas no special guidelines for the P/S ratio are given anymore (36). In all clusters the mean contribution of saturated fatty acids to energy intake was much higher than $10 \%$ [range $13.5 \%$ (cluster 8 ) to $20.6 \%$ (cluster 1 )]. These results suggest that the overall assessment of the cluster solutions with respect to risks for chronic diseases seems quite stable.

On the basis of total sum scores, more than $50 \%$ of the examined population had diets that departed substantially from the guidelines for a healthy diet. As pregnant women and subjects with a diet prescribed by a physician were excluded from cluster analysis the results cannot be generalized to the whole adult population. In comparing the results of our study with those of others, it should be realized that the methods used to collect and classify data vary among studies. Moreover, differences in dietary patterns among countries could also introduce cluster differences. Despite these limitations, results of studies abroad support several of our observations with regard to eating patterns and their characteristics. For example, another cluster analysis based on nutrient density of dicts consumed by US women aged 19-51 classified the population into nine groups. More than half of this US sample used diets of poor nutritional quality (37). Low-energy diets of poor nutritional quality were associated with women in households with lower income levels and with female heads of households with a lower level of education (37). Indicators of these 
characteristics were also overrepresented in our HFLA cluster. Akin et al. (30) reported that, with the aid of cluster analysis based on food intake, the food patterns of elderly people can be well categorized as light eaters, heavy eaters, or consumers of large amounts of alcoholic beverages, salty snack products, animal fat products, and so on, which agrees with some of the food group characteristics in our clusters, for instance in the HFHA cluster.

Our results indicate that the MFLA cluster can be identified as the cluster with the most prudent life-style, and this may partially be motivated by health considerations among its members. In this cluster subjects with a high SES were overrepresented. Other studies have also shown that a more pronounced healthconscious behaviour is often associated with a higher socio-economic status (38-40), resulting in a more favourable biochemical profile of cardiovascular risk factors (31). Theoretically, subjects with a higher SES could spend more money on food. Mooney (41) reported that healthy food choices appear to be more expensive. In our study the costs of the prudent diet of those in the MFLA cluster, associated with high SES, did not differ substantially from the costs of a poorer diet in the HFLA cluster in which more people were of low SES. In the clusters with a high alcohol consumption the diets were on average the most expensive (and remained so if the costs of alcoholic beverages were not taken into account), but no association with SES was found. These results have to be interpreted with caution, however, because both clusters with a high alcohol intake also had the highest energy intake ('largest eaters'). Comparing the costs per MJ revealed that the costs of the diets are influenced not only by quantity but also by quality.

In conclusion, our results show that cluster analysis can identify groups with noteworthy differences in mean nutrient intake and that this method can be considered as a useful tool for dietary risk group identification. Undesirable life-style variables are interrelated in some clusters, but an exclusive life-style for health risk has not been found. Our study does not provide a gond basis yet to deliver diversified recommendations for specific segments of the population. Future studies should try to find more sensitive indices that discriminate nutritional risks with a higher degree of specificity which may result in targeting of nutrition messages.

\section{References}

1. Breslow L. Enstrom JE. Persistence of health habits and their relationship to mortality. Prev Med 1980:9: 469-483.

2. Doll R. Peto R. The causes of cancer: quantitative estimates of avoidable risks of cancer in the United States today. J Natl Cancer Inst 1981:6: 1191-1308.

3. Wingard DL. Berkman LF. Brand RJ. A multivariate analysis of health-related practices. Am J Epidemiol 1982:116: 765-775.

4. Belloc NB. Breslow L. Relationship of health status and health practices. Prev Med 1972:1: 409-421. 
5. Baecke JAH, Burema J, Frijters JER, Hautvast JGAJ, Van de Wiel-Wetzels WAM Obesity in young adults: II Daily life-style and body mass index. Int J Obesity 1983;7: $13-24$.

6. Baecke JAH, Burema J, Frijters JER, Hautvast JGAJ, Van der Wiel-Wetsels WAM Obesity in young Dutch adults: I Socio-demographic variables and body mass index. Int J Obesity 1983:7: 1-12

7. Holme I, Helgeland A. Hjermann I, Lund-Larsen PG, Leren P. Coronary risk factors and socio-economic status - The Oslo study. Lancet 1976:ii: 1396-1399.

8. Noppa H, Bengtsson C. Obesity in relation to socio-economic status J Epidemiol Comm Health 1980;34: 139-142.

9. Duijkers TJ, Kromhout D. Spruit IP. Doornbos G. Intermediating factors in the relation between socio-economic status and 25-year mortality (The Zutphen Study). Int J Epidemiol 1989:18: 658-662.

10. Kok FJ, Matroos AW, Van den Ban AW, Hautvast JGAJ. Characteristics of individuals with multiple behavioral risk factors for coronary heart disease in The Netherlands. Am J Public Health 1982:72: 986-991.

11. Hulshof KFAM, Wedel M. Ockhuizen Th. Dietary intake, lifestyle and anthropometry of 18-year old men in The Netherlands. Nutr Rep Int 1988;37: $755-765$.

12. Löwik MRH. Westenbrink S. Wedel M. Schrijver J. De invloed van sociaal economische factoren op de voeding en voedingstoestand van ouderen. Voeding 1989:50: 38-42.

13. Löwik MRH, Borsboom AGB, Bun CJE. Kok FJ, Schouten EG. Odink J. Clustering cardiovasculaire risico-indicatoren bij ouderen. Hart Bulletin 1991;22: $95-99$.

14. Hulshof KFAM. Löwik MRH. Kok FJ. Wedel M, Brants HAM. Hermus RJJ. Ten Hoor F. Diet and other life-style factors in different socio-economic groups (Dutch Nutrition Surveillance System). Eur J Clin Nutr 1991:45: 44 1-450.

15. Hulshof KFAM. Van Staveren WA. The Dutch National Food Consumption Survey: design, methods and first results. Food Policy 1991:16: 257-260.

16. NEVO-Tabel. Nederlands Voedingsstoffenbestand 1986-1987. The Hague: Voorlichtingsbureau voor de Voeding. 1987.

17. Centraal Bureau voor de Statistiek. Bijvoegsel Maandstatistieken van de prijzen. Voorburg: CBS: 1987:12.

18. Centraal Bureau voor de Statistiek. Bijvoegsel Maandstatistieken van de prijzen. Voorburg: CBS; $1988: 13$.

19. Hartigon JA. Clustering Algorithms. New York:1975

20. Netherlandis Nutrition Council. Guidelines for a healthy diet. The Hague: Voedingsraad. 1986

21. Dixon WJ, Brown MB. Engelsman L. Frane JW, Hill MA. Jennrich RI. Toporek JD. BMDP statistical software. Berkley. University of California Press; 1990.

22. Axelson ML. The impact of culture on food-related behavior. Ann Rev Nutr 1986:6: $345-363$.

23. Lubben JE. Weiler PG. Chi J. Health practices of the elderly poor. Am J Public Health 1989:79: 731-734.

24. Shaw M, Jeffry RW. Hannan PJ, Onstod L. Relationship between socio-demographic and behaviour variables, and body mass index in a population with high-normal blood pressure: hypertension prevention trial. Eur J Clin Nutr 1989:43: 583--596.

25. Solvoll K, Selmer R, Løken EB. Foss OP. Trygg K. Coffee, dietary habits, and serum cholesterol among men and women 35-49 years of age. Am J Epidemiol 1989:129: 1277-1288.

26. Lowik MRH, Westenbrink S. Hulshof KFAM, Kistemaker C. Hermus RJJ. Nutrition and aging: dietary intake of 'apparently healthy' elderly. J Am Coll Nutr 1989:8: $347-356$.

27. Cronin FJ, Krebs-Smith SM, Wyse BW, Light L. Characterizing food usage by demographic variables. J Am Diet Assoc 1982:81: 6́61-673. 
28. Schwerin HS, Stanton JL, Riley AM, Schaefer AE, Leveille GA, Elliott JG, Warwick KM, Brett BE. Food eating patterns and health: a reexamination of the Ten-State and HANES I surveys. Am J Clin Nutr 1981:34: 568-580.

29. Schwerin HS, Stanton JL, Smith JL, Riley AM, Brett BE. Food eating habits, and health: a further examination of the relationship between food eating patterns and nutritional health. Am J Clin Nutr 1982;35: 1319-1325.

30. Akin JS, Guilkey DK. Popkin BM, Fanelli MT. Cluster analysis of food consumption patterns of older Americans. J Am Diet Assoc 1986;86: 616-624.

31. Nicklas TA, Webber LS, Thompson B. Berenson GS. A multivariate model for assessing eating pattems and their relationship to cardiovascular risk factors. Am J Clin Nutr 1989:49: 1320-1327.

32. Randall E. Marshall J, Graham S, Brasure J. Patterns in food use and their associations with nutrient intakes. Am J Clin Nutr 1990:52: 739-745.

33. Beaton GH, Milner J. Corey P, McGuire V, Cousins M. Steward E, de Ramos M, Hewit D, Gramsch PV, Kassim N, Little JA. Sources of variance in 24-hour dietary recall data: implications for nutrition study design and interpretation. Am J Clin Nutr 1979:32: 2546-2559.

34. Netherlands Nutrition Council. Richtlijnen goede voeding. Voeding 1990:47: 159-181.

35. Boffetta P, Garfinkel L. Alcohol drinking and mortality among men enrolled in an American Cancer Society Prospective Study. Epidemiology 1990:1: 342-348

36. Netherlands Nutrition Council. Nader advies inzake de richtlijn m. b.t. de vetconsumptie uit het advies Richtlijnen goede voeding 1986. The Hague, 1991

37. Windham CT, Windham MP. Factors related to nutrient intake patterns of female participants in the USDA CSFII-1985 (abstract). J Am Diet Assoc 1990;90: (suppl)A-94.

38. Anonymous. Use of vitamin and mineral supplements in the United States. Nutr Rev 1990;48: 161-162.

39. Block G, Cox C. Madans J, Schreiber GB, Licitra L. Melia N. Vitamin supplement use, by demographic characteristics. Am J Epidemiol 1988:127: 297-309.

40. Koplan JP, Annest JL. Laydc PM, Rubin GL. Nutrient intake and supplementation in the United States (NHANES II). Am J Public Health 1986:76: 287-289.

41. Mooney C. Cost and availability of healthy food choices in a London health district. J Hum Nutr Diet 1990;3: 111-120. 



\title{
Is food variety conducive to a more adequate diet?
} (Dutch Nutrition Surveillance System)

\author{
K.F.A.M. Hulshof, M.R.H. Löwik, C. Kistemaker, F.ten Hoor, R.J.J. Hermus
}

\begin{abstract}
This study examines the impact of food variety on the intake of energy and nutrients in the diets of Dutch adults aged 22-49. Dietary intake was assessed by a two-day record method; nutrient density was used as criterion. The concept of food variety included variety among and within (major) food groups, and attention was also paid to the nutrient profile of food items. Subjects were assigned to five food variety categories, based on their position within the distribution for food variety, each category representing about $20 \%$ of the population. A larger degree of food variety was generally associated with a higher nutrient intake as well as a higher energy intake. However, no consistent association between food variety and nutrient density was observed. The proportion of subjects using one or more products from all major food groups (i.e. vegetables, fruits, potatoes, cereals, dairy, and meat) differed markedly among the categories, with the lowest proportions in those having low variety scores. Fruits and vegetables were the main determinants of these differences. A larger degree of variety was associated with a higher socio-economic status (SES) and a lower prevalence of some undesirable life-style factors. Among men, no relationship between body mass index (BMI) and food variety was observed, whereas women in the lowest category had the highest BMI. The results demonstrated that the association between food variety and dietary intake is determined mainly by differences in quantity (amounts) and to a lesser extent by differences in quality of the diet. Moreover, this study indicates that fulfilment of the guideline 'Eat a variety of food' will not automatically lead to a more adequate diet.
\end{abstract}

\section{Introduction}

Eating a variety of foods is often considered to be a key factor in realizing dietary adequacy. In the Dutch Guidelines for a healthy diet the consumption of a wide range of foods is recommended to increase assurance of adequate nutrient intake, to avoid deficiencies and excessively hig intakes of single nutrients, and to reduce the 
likelihood of high exposure to contaminants through food consumption (1). Other countries also advocate the consumption of a varied diet (2-5).

Although the slogan 'eat a variety of foods' seems to convey a relatively simple message, consumers may interpret this message differently. One interpretation may be that every food product is considered to be unique, regardless of similarities in composition. Variety may also refer to the selection of foods from different major food groups [e.g., 6 groups in the USA (6)], whereby at least one product belonging to each of these groups should be consumed daily. Other concepts of food variety are related to selection of a variety of foods from within food groups $(7,8)$ and/or to the choice of different preparation methods (9).

In the USA a recent study among young adults supports the traditional belief that diets composed of foods from all major food groups are more likely to be nutritionally adequate (10). Studies using other principles or parameters of variety indicate that the effects on nutritional adequacy may differ for several nutrients (11) and may also depend on the number of food products (12).

Eating patterns across countries may differ widely, and data from North America, for example, cannot be generalized to all industrialized countries. As far as we know, little information is available in Europe on the relationship between variety in food consumption and dietary adequacy. The aim of our study is to assess the influence of variety on intake of energy and nutrients in the Netherlands in a representative sample of adults aged $22-49$, using a comprehensive model in which different aspects of variety are taken into account simultaneously.

\section{Methods}

The first Dutch National Food Consumption Survey (DNFCS) was conducted in $1987-1988$ on a probability sample of 5898 non-institutionalized Dutch subjects aged $1-85$ (response rate $81 \%$ ). Details of the survey design and data collection procedures have been described elsewhere (13). For the purpose of this study, a subset composed of adults 22 to 49 years old was created. According to the Dutch recommended dietary allowances (14) age is considered to have no substantial effect on the requirement of energy and nutrients within this age range. Pregnant women $(n=52)$ and subjects on a diet (either prescribed or on the subject's own initiative, $n=306$ ) were excluded because these conditions a re likely to affect food selection and hence variety in the usage of food products. The analytical sample included 2316 subjects ( 1145 men and 1171 women).

Dietary intake was assessed by a two-day record method. In each household the person principally responsible for domestic affairs (main housekeeper) was the most important informant and was visited on two occasions by a specially trained dietitian. During the first visit the household diary was explained. In this diary all food supplied by the main housekeeper to the members of the household was recorded. Precise description of methods of cooking, recipes and ingredients was requested. In addition, a diary was kept by each respondent to note food eaten outdoors. In 
recording six different kinds of meals and consumption events were distinguished: three meals (breakfast, lunch, dinner) and foods consumed between breakfast and lunch, between lunch and dinner, and after dinner, respectively. The respondents were distributed equally over the seven days of the week and over a whole year (holiday periods excluded) to obtain a representative picture of the Dutch diet. For each individual the intake of foods and nutrients was calculated per mean day. Intake from nutritional supplements was not quantified.

The concept of variety was studied by means of a procedure of progressive deepening, starting with variety among food groups (i. e. number of different food groups used during the record period), variety within food groups (i. e. number of different products within food groups), variety in the total number of unique food items per food group and, finally, variety in the nutrient profile of unique food items (Fig. 7.1). In total, 759 different food items [codes corresponding with the Dutch Food Composition Table, version 1987/1988 (15)], were reported by the respondents in two-day periods. To avoid artificial inflation of variety, which might be introduced by the use of a wide range of food items from only one type of food (for example, 25 different kinds of fruits) an a priori classification was applicd. All unique food items were classified into 43 food groups based on food origin and

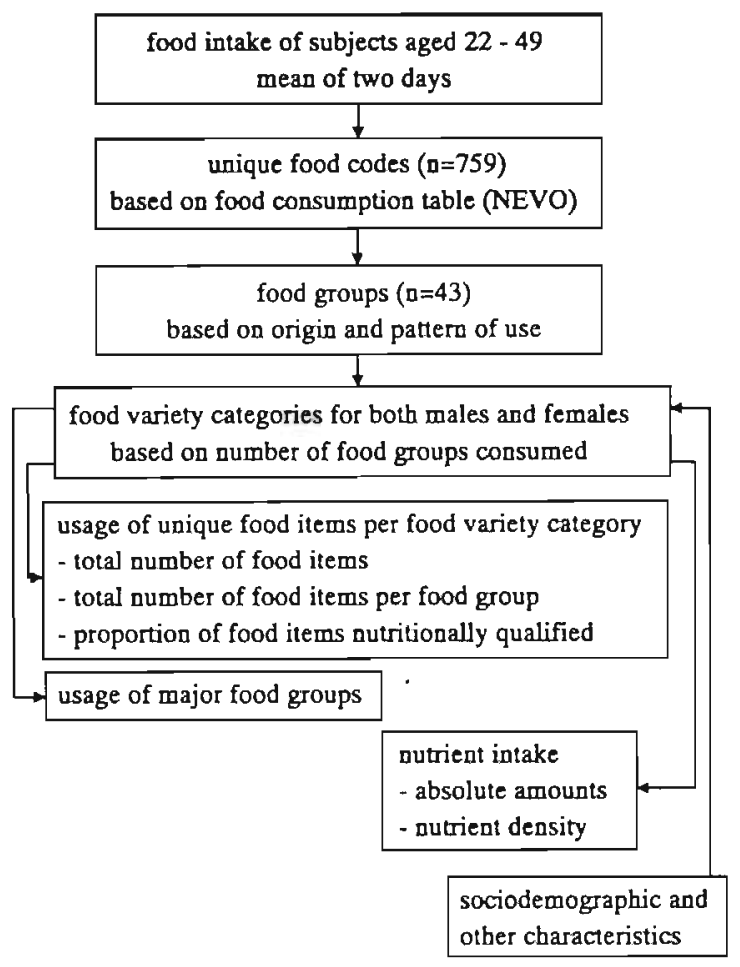

Fig. 7.1. Procedure of studying food variety. 
pattern of use. For instance, although liver sausage and pork rib chop are both of animal origin, in a Dutch diet the first item is mostly a component of bread-based meals and in-between meals, whereas the second one is usually consumed for dinner: therefore sausages and other meat products were considered to represent different groups. Herbs, seasonings, flavourings etc. were combined into the group 'miscellaneous'. The 43 food groups are described in Annex 7.1. For each subject the number of food groups from which at least one product was consumed during the days of recording was calculated and used as a classification criterion. To simplify reporting of results, subjects were assigned to 5 categories on the basis of their position within the distribution for food variety (for men and women separately), each category representing about $20 \%$ of the population. For each category the proportion of users was calculated for the 43 food groups and differences among categories were examined using $x^{2}$ tests (16).

Furthermore, within each of the five categories the concept of variety was extended by counting the total number of unique food items. Moreover, all food items were divided into three classes (type A, B and C), using nutritive criteria developed by the Netherlands Bureau for Nutrition Education (8). In 1991, this bureau introduced the 'Foodpointer', a model in which all foods can be grouped into four segments, referring to their carbohydrate, fat, protein and vitamin $\mathrm{C}$ contents. Within each segment food items are characterized as foods for which, from a nutritional point of view, the choice is to be stimulated (A), acceptable (B), or acceptable only exceptionally (C). Annex 7.2 describes the criteria for the four segments. Several nutrition education models advocate a daily use of at least one product from each major food group. The approach of food variety described makes it also possible to study this aspect by linking several food groups presented in Annex 7.1.

To examine the impact of food variety on the intake of nutrients and nutrient density, the average intake for the five categories of variety was calculated. Since type of day may influence dietary variety, comparison of the dietary intake figures among categories was made on means, adjusted for week days and weekend days by analysis of covariance. Trends in mean values across all the categories were tested by regression analysis, adjusted for type of day. The assumptions underlying these analyses regarding the residuals, namely equality of variance and normality, were checked before analysis. When a distribution was skewed (as was the case for alcohol, $\mathrm{P} / \mathrm{S}$ ratio, riboflavin, vitamin $\mathrm{C}$ and for some nutrients expressed per $\mathrm{MJ}$ (cholesterol, dietary fibre, calcium, iron, retinol, B vitamins, vitamin C)), values were transformed logarithmically. The associations between discrete variables (e.g. sociodemographic factors, smoking, breakfast use, obesity (based on body mass index, classification according to Garrow (17)) and categories of food variety were analysed with log-linear models (18). Data analyses were performed with BMDP statistical software (19). Differences with a $P$ value $<0.05$ were considered statistically significant in two-tailed tests. 


\section{Results}

The number of food groups consumed by individuals during the two days varied from 6 to 32 among men, and from 9 to 33 among women. In almost all food variety categories the number of unique food items consumed during two days was higher among women than among men. The number of unique items increased from the category with the lowest to that with the highest food variety by 119 (men) and 96 (women) food items (Table 7.1). Compared with the lowest variety category, subjects in the highest category consumed more different kinds of vegetables (raw and cooked), fruits (for men more preserved fruits), cereals (bread excepted), cheese (especially types from abroad), poultry, meat products (for men only), fish, biscuits \& pastry, candies \& chocolate, nuts and other savoury snacks, alcoholic beverages and syrups. The larger variety within these food groups accounted for $73 \%$ and $77 \%$, respectively, of the difference in number of unique food items between men and women in the lowest and the highest category. Both for men and women in all categories type $\mathrm{A}$ foods accounted for more than $40 \%$ of the total number of food items, and food items characterized as type $B$ and type $C$ each for nearly $30 \%$ (Table 7.1).

Table 7.2 presents the proportions of users for food groups with a difference of at least 15 percentage units among the categories of male and/or female users, and the proportion of users consuming at least one product from all major food groups (vegetables, fruits, potatoes, cereals, dairy, meat; see Annex 7.1). Both for men and women the proportion of subjects eating bread and using spreadable/cooking fat did not differ across the categories. These food groups were consumed by at least $96 \%$ and $94 \%$, respectively, of the various population groups. The percentage of users of meat ranged among men from 89 (category 1) to 98 (category 2) and among women from 85 (category 1) to 90 (categories 2 and 5). For the other food groups the lowest

Table 7.1. Mean number of food groups and number of unique food items according to food variety categories ${ }^{1}(1-5)$ represented in two-day food records among adults aged $22-49$.

\begin{tabular}{|c|c|c|c|c|c|c|c|c|c|c|}
\hline \multirow[b]{3}{*}{ Sub-population size } & \multicolumn{2}{|c|}{ Calegory 1} & \multicolumn{2}{|c|}{ Category 2} & \multicolumn{2}{|c|}{ Category 3} & \multicolumn{2}{|c|}{ Category 4} & \multicolumn{2}{|c|}{ Caiegory 5} \\
\hline & men & women & men & women & men & women & men & women & men & women \\
\hline & 248 & 285 & 243 & 210 & 223 & 246 & 213 & 201 & 218 & 219 \\
\hline Food groups represented & 15.4 & 15.1 & 18.5 & 18.5 & 20.5 & 20.5 & 224 & 224 & 25.4 & 25.5 \\
\hline Unique food items & 483 & 530 & 529 & 525 & 561 & 590 & 573 & 573 & 602 & 626 \\
\hline Type A foods? & 206 & 242 & 225 & 226 & 238 & 257 & 245 & 246 & 263 & 278 \\
\hline Type B foods & 138 & 143 & 153 & 155 & 102 & 167 & {$[68$} & 163 & $174 \mid$ & 176 \\
\hline Type C foods & 139 & 145 & 151 & 144 & 161 & 166 & 156 & 164 & 165 & 172 \\
\hline
\end{tabular}

' Category limits for number of food groups are: $\leq 17.18-19,20-21.22-23$ and $\geq 24$ (maximum 43 food groups).

${ }^{2} \mathrm{~A}$, to be stimulated. B, acceptable; $\mathrm{C}$, to be consumed just occasionally. 
proportion of users was observed in the lowest variety group, and the highest proportion in the categories with higher food variety. The percentage of subjects using one or more products from all major food groups varied markedly among the categories, with the lowest proportion among those having low food variety.

Differences in the use of fruits, followed by that of vegetables, are the main determinants of these findings. In the lowest variety category $31 \%$ (women) and $40 \%$ (men) did not consume any fruits (neither fresh nor preserved fruits nor fruit juices), and about $15 \%$ did not use vegetables (neither cooked nor fresh salads). Mostly, mean daily consumption of the food groups (in grams) was highest in the higher variety groups. No (relevant) differences in consumed amounts were observed for potatoes, meat, meat products, cooked vegetables and pasta (only for men) (results not shown).

In studying the relation between type of day (week day or weekend day) and food variety, a higher variety appeared to be associated with weekend days as compared to week days. No differences were found as to seasonal distribution

Table 7.2. Lisers (\%) of selected food groups according to categories $(1-5)$ of food variety. ${ }^{1}$

\begin{tabular}{|c|c|c|c|c|c|c|c|c|c|c|}
\hline \multirow{2}{*}{$\begin{array}{l}\text { Food group } \\
\text { Category }\end{array}$} & \multicolumn{5}{|l|}{ Men } & \multicolumn{5}{|c|}{ Women } \\
\hline & 1 & 2 & 3 & 4 & 5 & 1 & 2 & 3 & 4 & 5 \\
\hline Sub-population size & 248 & 244 & 223 & 217 & 218 & 285 & 210 & 246 & 201 & 229 \\
\hline Potatoes, cooked & 73 & 76 & 80 & 83 & 85 & 64 & 80 & 77 & 82 & 80 \\
\hline Salad vegetables & 22 & 33 & 48 & 53 & 71 & 30 & 40 & 5.9 & 54 & 74 \\
\hline Cooked vegetables & 78 & 87 & 86 & 93 & 95 & 78 & 88 & 88 & 94 & 95 \\
\hline Fresh fruits & 50 & 57 & 69 & 75 & 79 & 54 & 69 & 76 & 75 & 86 \\
\hline Preserved fruits & 10 & 19 & 25 & 31 & 46 & 17 & 20 & 30 & 29 & 55 \\
\hline Pasta, rice & 15 & 26 & 25 & 27 & 35 & 21 & 27 & 31 & 29 & 35 \\
\hline Other cereals & 32 & 41 & 53 & 60 & 70 & 29 & 42 & 46 & 63 & 09 \\
\hline Rusks, crackers & 16 & 26 & 36 & 45 & 62 & 20 & 37 & 45 & 63 & 67 \\
\hline Milk & 63 & 74 & 82 & 82 & 91 & 58 & 78 & 80 & 81 & 91 \\
\hline Desserts & 38 & 56 & 66 & 71 & 76 & 36 & 61 & 67 & 68 & 77 \\
\hline Cream & 54 & 63 & 70 & 73 & 80 & 40 & 50 & 56 & 71 & 72 \\
\hline Hard cheese & 67 & 71 & 80 & 74 & 88 & 67 & 75 & 80 & 85 & 90 \\
\hline Eggsi & 37 & 52 & 61 & 59 & 74 & 38 & 51 & 64 & 67 & 71 \\
\hline Poultry & 10 & 13 & 17 & 27 & 26 & 9 & 12 & 21 & 18 & 28 \\
\hline Meat products & 73 & 79 & 82 & 88 & 90 & 59 & 62 & 75 & 75 & 86 \\
\hline Fish & 8 & 11 & 19 & 20 & 28 & 7 & 12 & 11 & 15 & 23 \\
\hline Dressings & 24 & 42 & 49 & 62 & 70 & 27 & 41 & 44 & 61 & 71 \\
\hline Mixed dishes & 14 & 24 & 25 & 27 & 34 & 21 & 19 & 22 & 26 & 38 \\
\hline Biscuits/pastries & 49 & 73 & 79 & 89 & 94 & 59 & 78 & 87 & 94 & 97 \\
\hline Sugar & 71 & 82 & 81 & 92 & 93 & 49 & 62 & 72 & 85 & 83 \\
\hline Confectionery & 18 & 30 & 42 & 53 & 68 & 24 & 44 & 55 & 61 & 78 \\
\hline Jam, honey, etc. & 33 & 47 & 55 & 69 & 75 & 34 & 56 & 64 & 66 & 72 \\
\hline Nuts and seeds & 8 & 15 & 25 & 32 & 46 & 10 & 14 & 24 & 33 & 51 \\
\hline Diy savoury snacks & 17 & 24 & 27 & 36 & 52 & 18 & 23 & 35 & 38 & 51 \\
\hline Peanut butter & 13 & 22 & 18 & 26 & 32 & 11 & 19 & 17 & 20 & 19 \\
\hline Fruit juices & 14 & 13 & 21 & 24 & 39 & 19 & 31 & 33 & 40 & 54 \\
\hline Soft drinks & 25 & 40 & 46 & 48 & 51 & 38 & 40 & 42 & 46 & 53 \\
\hline Alcoholic beverages & 62 & 64 & 71 & 66 & 83 & 38 & 39 & 46 & 50 & 66 \\
\hline $\begin{array}{l}\text { One or more foods from } \\
\text { all major food groups }\end{array}$ & 50 & 65 & 77 & 80 & 93 & 56 & 75 & 83 & 84 & 96 \\
\hline
\end{tabular}

' See Table 7. 1. Differences larger than ? percentage units are statistically significant $(P<0.05)$. 
among categories of food variety. Therefore, statistical analyses were adjusted only for week days and weekend days.

Tables 7.3 and 7.4 summarize data (unadjusted values) on the intake of energy and nutrients for different food variety categories. The results indicate that mcan values for absolute intake of almost all nutrients, as well as for energy intake, were higher at a higher level of food variety. A significant positive trend was also observed for the intake of energy and protein intake, when expressed per kg body weight (results not shown). No consistent pattern for the relation between food variety and nutrient density was observed. The intake of protein (only for men), fat and alcohol as a percentage of energy intake did not differ substantially among the categories, whereas the contribution of carbohydrates to energy intake appeared to be larger for groups with a higher variety. The intake per MJ of vitamin $\mathrm{C}$ among men and women, and of calcium among men, showed an increasing trend with food variety,

Table 7.3. Daily intake of energy and nutrients (mean \pm SD) among men aged $22-49$, according to category of food variety' $(1-5)$.

\begin{tabular}{|c|c|c|c|c|c|c|c|}
\hline Variable & $\begin{array}{l}\text { Cat. } 1 \\
(n=248)\end{array}$ & $\begin{array}{l}\text { Cat } 2 \\
(n=243)\end{array}$ & $\begin{array}{l}\text { Cat. } 3 \\
(n=223)\end{array}$ & $\begin{array}{l}\text { Cat. } 4 \\
(n=2 \mid 3)\end{array}$ & $\begin{array}{l}\text { Cat. } 5 \\
(n: \ldots 218)\end{array}$ & Trend 2 & $\begin{array}{l}\text { RDA or } \\
\text { guideline }\end{array}$ \\
\hline Energy (MJ) & $10.7 \pm 2.9$ & $11.5 \pm 2.5$ & $12.0 \pm 2.7$ & $12.6 \pm 2.5$ & $13.5 \pm 2.8$ & $<0.001$ & \\
\hline Protein (g) & $82 \pm 24$ & $88 \pm 23$ & $91 \pm 25$ & $94 \pm 22$ & $101 \pm 23$ & $<0.001$ & \\
\hline Total fat (g) & $114 \pm 41$ & $124 \pm 37$ & $127 \pm 38$ & $135 \pm 37$ & $144 \pm 39$ & $<0.001$ & \\
\hline P/S ratio & $0.44 \pm 0.18$ & $0.44 \pm 0.21$ & $0.45 \pm 0.18$ & $0.47 \pm 0.19$ & $0.45 \pm 0.15$ & & \\
\hline Cholesterol (mg) & $310 \pm 137$ & $357 \pm 147$ & $367 \pm 156$ & $365 \pm 148$ & $416=159$ & $<0.001$ & \\
\hline $\mathrm{MD}^{3}(\mathrm{~g})$ & $117 \pm 59$ & $132 \pm 54$ & $141 \pm 50$ & $157 \pm 51$ & $167 \pm 60$ & $<0.001$ & \\
\hline Carbohydrates (g) & $256 \pm 84$ & $285 \pm 79$ & $295 \pm 75$ & $321 \pm 76$ & $340 \pm 86$ & $<0.001$ & \\
\hline Dietary fibre $(\mathrm{g})$ & $24.6 \pm 9.9$ & $25.5 \pm 10.2$ & $26.9 \pm 9.5$ & $29.1 \pm 9.7$ & $30.0 \pm 9.7$ & $<0.001$ & \\
\hline Alcohol (g) & $25 \pm 30$ & $21 \pm 24$ & $25 \pm 27$ & $19 \pm 22$ & $24 \pm 21$ & & \\
\hline Calcium (mg) & $1052 \pm 586$ & $1105 \pm 457$ & $1164 \pm 455$ & $1185 \pm 437$ & $1311=419$ & $<0.001$ & $700-900$ \\
\hline Iron (mg) & $12.3 \pm 4.0$ & $13.2 \pm 4.1$ & $13.7 \pm 3.7$ & $14.7 \pm 3.9$ & $15.5 \pm 3.8$ & $<0.001$ & $y$ \\
\hline Retinol (mg) & $1.02 \pm 0.73$ & $0.95 \pm 0.50$ & $1.07 \pm 1.02$ & $1.16 \pm 1.30$ & $1.19 \pm 0.70$ & $<0.001$ & 1.0 \\
\hline Thiamin (mg) & $1.21 \pm 0.44$ & $1.27 \pm 0.46$ & $1.26 \pm 0.42$ & $1.31 \pm 0.38$ & $1.35 \pm 0.40$ & $<0.001$ & 1.1 \\
\hline Riboflavin (mg) & $1.71 \pm 0.74$ & $1.79 \pm 0.62$ & $1.89 \pm 0.59$ & $1.93 \pm 0.59$ & $2.03 \pm 0.59$ & $<0.001$ & 1.6 \\
\hline Vitamin B-6 (mg) & $1.43 \pm 0.52$ & $1.49=0.50$ & $1.55 \pm 0.49$ & $1.65 \pm 0.50$ & $1.71 \pm 0.52$ & $<0.001$ & 1.5 \\
\hline Vitamin C (mg) & $61 \pm 55$ & $61 \pm 47$ & $81 \pm 68$ & $83 \pm 57$ & $88 \pm 56$ & $<0.001$ & 70 \\
\hline \multicolumn{8}{|l|}{ Wof energy inuake } \\
\hline Protein & $13.1 \pm 3.1$ & $13.0 \pm 2.6$ & $12.8 \pm 2.7$ & $12.5 \pm 2.3$ & $12.7 \pm 2.2$ & & \\
\hline Saturated fat & $16.1 \pm 3.7$ & $16.5 \pm 3.2$ & $16.1 \pm 3.1$ & $16.1 \pm 2.8$ & $16.2 \pm 2.7$ & & $\leq 10$ \\
\hline Total fat & $39.8 \pm 8.4$ & $40.4 \pm 6.6$ & $39.7 \pm 6.0$ & $40.3 \pm 6.2$ & $40.0 \pm 5.7$ & & $30-35$ \\
\hline $\mathrm{MD}^{3}$ & $18.4 \pm 7.8$ & $19.2 \pm 6.7$ & $20.0 \pm=6.2$ & $20.9 \pm 5.7$ & $20.7 \pm 5.5$ & $<0.001$ & $15-25$ \\
\hline Carbohydrates & $40.2 \pm 7.8$ & $41.5 \pm 6.8$ & $41.6 \pm 6.7$ & $42.8 \pm 6.8$ & $42.2 \pm 6.1$ & $<0.001$ & $\geq 50$ \\
\hline Alcohol & $6.8 \pm 7.8$ & $5.2 \pm 5.8$ & $5.9 \pm 6.2$ & $4.4 \pm 4.9$ & $5.1 \pm 4.5$ & & \\
\hline \multicolumn{8}{|l|}{ linake per MJ } \\
\hline Cholesterol (mg) & $30 \pm 12$ & $31 \pm 12$ & $31 \pm 12$ & $29=10$ & $31 \pm 10$ & & $\leq 33$ \\
\hline Dietary fibre $(\mathrm{g})$ & $2.4 \pm 1.0$ & $2.2 \pm 0.8$ & $2.3 \pm 0.8$ & $2.3 \pm 0.7$ & $2.3 \pm 0.6$ & & $2: 3$ \\
\hline Calcium (mg) & $99 \pm 44$ & $98 \pm 39$ & $99 \pm 35$ & $95 \pm 33$ & $99=30$ & 0.03 & \\
\hline Iron $(\mathrm{mg})$ & $1.20 \pm 0.42$ & $1.17 \pm 0.31$ & $1.18 \pm 0.32$ & $1.18 \pm 0.28$ & $1.17 \pm 0.26$ & & \\
\hline Rerinol $(\mu g)$ & $97 \pm 66$ & $83 \pm 39$ & $90 \pm 87$ & $93 \pm 93$ & $90=54$ & & \\
\hline Thiamin $(\mu g)$ & $117 \pm 47$ & $111 \pm 36$ & $108 \pm 34$ & $105 \pm 28$ & $102 \pm 28$ & 0.02 & 95 \\
\hline Riboflavin $(\mu \mathrm{g})$ & $162 \pm 55$ & $158=46$ & $159 \pm 41$ & $155 \pm 42$ & $152 \pm 39$ & & \\
\hline Vitamin B-6 $(\mu \mathrm{g})$ & $138 \pm 51$ & $132 \pm 40$ & $133 \pm 42$ & $132 \pm 35$ & $128 \pm 35$ & & \\
\hline Vitamin C (mg) & $6.28 \pm 6.98$ & $5.57 \pm 4.62$ & $6.98 \pm 5.57$ & $6.76 \pm 4.80$ & $6.63 \pm 4.21$ & $<0.001$ & \\
\hline
\end{tabular}

I See Table 7.1. ${ }^{2}$ Trend across categories, $P$ values are presented. ${ }^{3}$ MD. mono- and disaccharides. 
whereas thiamin and vitamin B-6 (only significant among women) showed a decreasing trend.

Comparing intake values with the recommended dietary allowances [RDA, (14)] and the Guidelines for a healthy diet of the Netherlands Nutrition Council (1), in most male categories vitamin $\mathrm{C}$ intake (geometric mean) was lower than recommended [range 61\% (lowest category) to 103\% (highest category) of RDA]. Except for retinol in the three lowest categories, the (geometric) mean intake level of the other nutrients approached or exceeded the RDAs. Among women in all groups calcium consumption exceeded the RDA (105-141\%), but the intake of iron and vitamin $\mathrm{C}$ was (much) lower than recommended. Mean iron intake ranged from $64 \%$ (lowest category) to $89 \%$ (highest category) and vitamin C (geometric mean) from $56 \%$ to $96 \%$ of the RDAs. In the lowest category the intake of the other vitamins was $84-93 \%$ of the RDA, in category 2 the intake approached (95-99\%) or exceeded

Table 7.4. Daily intake of energy and nutrients (mean \pm SD) among women aged 22-49. according to category of food variety' ${ }^{1}(1-5)$.

\begin{tabular}{|c|c|c|c|c|c|c|c|}
\hline Variable & $\begin{array}{l}\text { Cat. 1 } \\
(n=285)\end{array}$ & $\begin{array}{l}\text { Cat. } 2 \\
(n=210)\end{array}$ & $\begin{array}{l}\text { Cat. } 3 \\
(n=246)\end{array}$ & $\begin{array}{l}\text { Cat. } 4 \\
(n=201)\end{array}$ & $\begin{array}{l}\text { Cat. } 5 \\
(n=229)\end{array}$ & Trend ${ }^{2}$ & $\begin{array}{l}\text { RDA or } \\
\text { guide line }\end{array}$ \\
\hline Energy (MJ) & $7.4 \pm 2.0$ & $8.4 \pm 2.0$ & $9.2 \pm 1.9$ & $9.6 \pm 1.9$ & $10.8 \div 2.2$ & $<0.001$ & \\
\hline Protein (g) & $62 \pm 17$ & $68 \pm 15$ & $73 \pm 16$ & $76 \pm 18$ & $83 \pm 19$ & $<0.001$ & \\
\hline Total fat (g) & $83 \pm 31$ & $93 \pm 28$ & $102 \pm 31$ & $108 \pm 30$ & $119 \pm 33<$ & $<0.001$ & \\
\hline P/S ratio & $0.39 \pm 0.20$ & $0.42 \pm 0.20$ & $0.41 \pm 0.18$ & $0.43 \pm 0.17$ & $0.44 \pm 0.15$ & $<0.001$ & \\
\hline Cholesterol (mg) & $247 \pm 117$ & $271 \pm 105$ & $299 \pm 113$ & $319 \pm 139$ & $346 \pm 116$ & $<0.001$ & \\
\hline $\mathrm{MD}^{3}(\mathrm{~g})$ & $85 \pm 45$ & $104 \pm 50$ & $114 \pm 43$ & $122 \pm 40$ & $139 \pm 46$ & $<0.001$ & \\
\hline Carbohydrates (g) & $181 \pm 61$ & $213 \pm 66$ & $228 \pm 59$ & $241 \pm 57$ & $271 \pm 63$ & $<0.001$ & \\
\hline Dietary fibre (g) & $18.1 \pm 6.7$ & $21.1 \pm 6.5$ & $22.0 \pm 7.2$ & $22.3 \pm 6.5$ & $24.2 \pm 6.7$ & $<0.001$ & \\
\hline Alcohol $(\mathrm{g})$ & $9 \pm 15$ & $8 \pm 15$ & $10 \pm 16$ & $10 \pm 14$ & $12 \pm 15$ & $<0.001$ & \\
\hline Calcium (mg) & $842 \pm 393$ & $970 \pm 401$ & $995 \pm 363$ & $1078 \pm 390$ & $1130=357$ & $<0.001$ & $700-900$ \\
\hline Iron (mg) & $9.7 \pm 2.9$ & $11.0 \pm 3.1$ & $11.8 \pm 3.0$ & $12.2 \pm 3.2$ & $13.4 \pm 3.4$ & $<0.001$ & 15 \\
\hline Retinol (mg) & $0.74 \pm 0.56$ & $0.80 \pm 0.42$ & $0.88 \pm 0.77$ & $0.94 \pm 0.74$ & $0.93=0.41$ & $<0.001$ & 0.8 \\
\hline Thiamin (mg) & $0.90=0.34$ & $0.99 \pm 0.34$ & $1.04 \pm 0.32$ & $1.02 \pm 0.31$ & $1.12 \pm 0.34$ & $<0.001$ & 1.0 \\
\hline Riboflavin (mg) & $1.27=0.58$ & $1.42=0.48$ & $1.51=0.49$ & $1.61 \pm 0.52$ & $1.68 \pm 0.44$ & $<0.001$ & 1.3 \\
\hline Vitamin B-6 (mg) & $1.05 \pm 0.39$ & $1.18=0.33$ & $1.26 \pm 0.36$ & $1.27 \pm 0.37$ & $1.40 \pm 0.41$ & $<0.001$ & 1.2 \\
\hline Vitamin $\mathrm{C}(\mathrm{mg})$ & $54 \pm 46$ & $66 \pm 45$ & $70 \pm 49$ & $67 \pm 41$ & $80 \pm 48$ & $<0.001$ & 70 \\
\hline \multicolumn{8}{|l|}{ \% of energy intake } \\
\hline Protein & $14.4 \pm 3.5$ & $13.8 \pm 2.7$ & $13.6 \pm 2.8$ & $13.3 \pm 2.5$ & $13.0 \pm 2.5$ & $<0.001$ & \\
\hline Saturated fat & $17.4 \pm 3.9$ & $17.1 \pm 3.1$ & $17.3 \pm 3.2$ & $17.3 \pm 2.8$ & $17.0 \pm 2.7$ & & $\leq 10$ \\
\hline Total fat & $41.2 \pm 8.4$ & $41.3 \pm 6.4$ & $41.5 \pm 6.9$ & $41.7 \pm 6.1$ & $41.4 \pm 5.4$ & & $30-35$ \\
\hline $\mathrm{MD}^{3}$ & $19.0 \pm 7.9$ & $20.3 \pm 6.9$ & $20.7 \pm 6.4$ & $21.2 \pm 5.7$ & $21.7 \pm 5.5$ & $<0.001$ & $15-25$ \\
\hline Carbohydrates & $40.7 \pm 8.4$ & $42.1 \pm 6.8$ & $41.7 \pm 6.9$ & $42.1 \pm 6.7$ & $42.3 \pm 6.2$ & 0.01 & $\geq 50$ \\
\hline Alcohol & $3.6 \pm 6.1$ & $2.8 \pm 4.8$ & $3.2 \pm 4.7$ & $2.8 \pm 4.1$ & $3.3 \pm 3.9$ & & \\
\hline \multicolumn{8}{|l|}{ Intake per MII } \\
\hline Cholesterol (mg) & $33 \pm 14$ & $33 \pm 13$ & $33 \pm 13$ & $33 \pm 12$ & $32 \pm 10$ & & $\leq 33$ \\
\hline Dietary fibre (g) & $2.5 \pm 1.0$ & $2.5 \pm 0.7$ & $2.4 \pm 0.8$ & $2.4 \pm 0.7$ & $2.3 \pm 0.7$ & & $\geq 3$ \\
\hline Calcium (mg) & $116 \pm 53$ & $117 \pm 46$ & $111 \pm 41$ & $113 \pm 37$ & $107 \pm 35$ & & \\
\hline Ifon (mg) & $1.35 \pm 0.43$ & $1.33 \pm 0.36$ & $1.32 \pm 0.34$ & $1.29 \pm 0.32$ & $1.26 \pm 0.31$ & 0.04 & \\
\hline Retinol ( $\mu \mathrm{g})$ & $100=69$ & $97 \pm 48$ & $99 \pm 115$ & $98 \pm 77$ & $87 \pm 38$ & & \\
\hline Thiamin $(\mu g)$ & $126 \pm 47$ & $120 \pm 37$ & $115 \pm 35$ & $108 \pm 31$ & $106 \pm 32$ & $<0.001$ & 95 \\
\hline Riboflavin ( $\mu \mathrm{g})$ & $176 \pm 74$ & $171 \pm 51$ & $169 \pm 57$ & $169 \pm 49$ & $160 \pm 44$ & & \\
\hline Vitamin B.6 $(\mu \mathrm{g})$ & $146 \pm 53$ & $144 \pm 41$ & $140 \pm 39$ & $134 \pm 37$ & $132 \pm 36$ & 0.04 & \\
\hline Vitamin C (mg) & $7.78 \pm 7.31$ & $8.21 \pm 5.68$ & $7.86 \pm 5.62$ & $7.25 \pm 4.98$ & $7.78 \pm 5.02$ & 0.01 & \\
\hline
\end{tabular}

1 See Table 7.1. "Trend across categories, $P$ values are presented. ${ }^{3}$ MD. mono- and disaccharides. 
Table 7.5. Age and some anthropometric variables (mean $\pm \mathrm{SD}$ ) among men and women aged $22-49$, according to category of food variety ${ }^{1}(1-5)$.

\begin{tabular}{|c|c|c|c|c|c|c|}
\hline Variable & Cat. 1 & Cat 2 & Cat 3 & Cat. 4 & Cat. 5 & Trend $^{2}$ \\
\hline \multicolumn{7}{|l|}{ Men } \\
\hline$n$ & 248 & 243 & 223 & 213 & 218 & \\
\hline Age & $35.0 \pm 7.3$ & $34.9 \pm 7.3$ & $35.0 \pm 7.3$ & $34.7 \pm 7.4$ & $34.4 \pm 6.9$ & \\
\hline Body weight (kg) & $77.6 \pm 10.5$ & $77.8 \pm 10.9$ & $77.8 \pm 11.1$ & $78.7 \pm 8.5$ & $77.8 \pm 9.6$ & \\
\hline Body height $(\mathrm{cm})$ & $179.4 \pm 7.5$ & $179.5 \pm 7.3$ & $180.0 \pm 6.8$ & $181.0 \pm 7.0$ & $180.9 \pm 7.1$ & $<0.001$ \\
\hline $\mathrm{BMI}^{3}\left(\mathrm{~kg} / \mathrm{m}^{2}\right)$ & $24.1 \pm 3.1$ & $24.2 \pm 3.1$ & $24.0 \pm 2.9$ & $24.0 \pm 2.4$ & $23.8 \pm 2.7$ & \\
\hline \multicolumn{7}{|l|}{ Women } \\
\hline$n$ & 285 & 210 & 246 & 201 & 229 & \\
\hline Age & $34.7 \pm 7.5$ & $34.6 \pm 7.7$ & $33.9 \pm 7.7$ & $34.0 \pm 7.5$ & $34.3 \pm 7.4$ & \\
\hline Body weight $(\mathrm{kg})$ & $65.4 \pm 11.1$ & $62.4 \pm 8.0$ & $63.5 \pm 9.4$ & $62.8 \pm 8.8$ & $64.7 \pm 9.9$ & \\
\hline Body height $(\mathrm{cm})$ & $166.8 \pm 6.1$ & $166.9 \pm 6.7$ & $167.5 \pm 6.7$ & $167.9 \pm 6.0$ & $168.2 \pm 6.4$ & $<0.001$ \\
\hline $\mathrm{BMI}^{3}\left(\mathrm{~kg} / \mathrm{m}^{2}\right)$ & $23.5 \pm 3.8$ & $22.4 \pm 2.5$ & $22.7 \pm 3.2$ & $22.3 \pm 2.8$ & $22.8 \pm 3.2$ & 0.01 \\
\hline
\end{tabular}

' See Table 7.1. ${ }^{2}$ Trend across categories, $P$ values are presented. ${ }^{3} \mathrm{BMI}$, body mass index.

(riboflavin) the RDA, and in the other categories the intake was in agreement with or above the recommended level. Both for men and women the intake of saturated fatty acids and total fat was higher and the intake of total carbohydrates and dietary fibre was lower than formulated in the guidelines for a healthy diet. The Netherlands Nutrition Council suggests for energy intake an adequate level of $148 \mathrm{~kJ} / \mathrm{kg}$ body weight for men aged $22-49$ and $134 \mathrm{~kJ} / \mathrm{kg}$ body weight for women (14). In all categories, except in the lowest group for men and women, these values were exceeded (highest mean intake for both men and women in the highest variety group was $176 \mathrm{~kJ} / \mathrm{kg}$ and $170 \mathrm{~kJ} / \mathrm{kg}$, respectively).

Both for men and women food variety was not associated with age and body weight (Table 7.5). Body height was highest in the higher food variety categories .Among women a decreasing trend for BMI with food variety was found; in the lowest category of food variety the proportion of subjects with obesity (BMI $\geq 30$ $\mathrm{kg} / \mathrm{m}^{2}$ ) was significantly higher than in the higher groups ( $7.4 \%$ vs. $2 \%$, respectively).

As shown in Table 7.6, higher variety was associated with a lower proportion of smokers, a higher proportion of subjects with an intermediate (among women) or higher education (among men), a higher SES and less breakfast skippers.

\section{Discussion}

We studied the influence of food variety behaviour on parameters of adequacy of the dietary pattern over a two- day period among adults aged 22-49. The data clearly indicate that a higher level of food variety is associated generally with a higher nutrient intake and a higher energy intake. However, we could not observe a consistent pattern for the relation between food variety parameters and nutrient density figures. Positive trends were found for carbohydrates, vitamin $\mathrm{C}$ and calcium, whereas for protein, thiamin and vitamin B-6 the reverse was shown. This 
Table 7.6. Sociodemographic and life-style characteristics according to category of food variety" and gender.

\begin{tabular}{|c|c|c|c|c|c|c|c|c|c|c|c|c|}
\hline \multirow[b]{3}{*}{$n$} & \multicolumn{2}{|c|}{ Category 1} & \multicolumn{2}{|c|}{ Category 2} & \multicolumn{2}{|c|}{ Category 3} & \multicolumn{2}{|c|}{ Category 4} & \multicolumn{2}{|c|}{ Category 5} & \multicolumn{2}{|c|}{ Difference $^{2}$} \\
\hline & men & women & men & women & men & women & men & women & men & women & men & women \\
\hline & 248 & 285 & 243 & 210 & 223 & 246 & 213 & 201 & 218 & 229 & & \\
\hline Smokers & 61.3 & 55.4 & 50.0 & 49.0 & 55.2 & 45.9 & 39.0 & 35.3 & 34.6 & 37.6 & $<0.001$ & $<0.001$ \\
\hline Education ${ }^{3}$ & & & & & & & & & & & $<0.001$ & $<0.01$ \\
\hline low & 45.5 & 39.1 & 41.0 & 33.3 & 32.4 & 33.2 & 37.8 & 29.5 & 253 & 23.9 & & \\
\hline high & 14.9 & 10.8 & 18.8 & 11.0 & 25.7 & 16.0 & 23.4 & 18.5 & 32.7 & 16.8 & & \\
\hline SES ${ }^{3}$ & & & & & & & & & & & $<0.001$ & $<0.01$ \\
\hline low & 55.6 & 53.0 & 48.0 & 42.9 & 44.0 & 44.3 & 47.4 & 34.3 & 35.9 & 38.0 & & \\
\hline high & 7.7 & 8.8 & 8.6 & 9.0 & 9.0 & 10.6 & 8.0 & 12.4 & 15.2 & 12.7 & & \\
\hline \multicolumn{13}{|l|}{ Skipping breakfast } \\
\hline on 2 days & 25.0 & 18.0 & 14.8 & 10.0 & 8.5 & 6.5 & 9.4 & 7.0 & 4.1 & 4.4 & $<0.001$ & $<0.001$ \\
\hline
\end{tabular}

See Table 7.1.

2 Statistically significant differences between food variety categories ( $P$ values).

${ }^{3}$ Low education: primary school or low vocational training; high education: university or high vocational training; socioeconomic status (SES) is based on educational level, occupation and occupational position of the head of the household.

inconsistency may be due to the limited range over which most of the food variety scores were found. The difference in mean values for variety between the lowest and the highest variety category was only 6 of a maximum of 43 food groups.

Furthermore, the lowest category of variety may already have a degree of variety that may be sufficient for reaching most of the aims underlying the guideline 'Eat a variety of foods' and thus surpass the threshold.

Our data do not refer to habitual consumption at the individual level. However, it is questionable whether habitual consumption is the appropriate time frame, since in the long run many more people will have eaten a particular foodstuff once. Furthermore, in our study we were interested in differences among population groups rather than among individuals. The data based on two days provide accurate estimates of group means. Previous studies, mostly based on one-day recall, have also reported an association between dietary adequacy and scores based on representation of (major) food groups in the diet (10-12, 20-23). Besides a positive trend for food variety and absolute amounts of selected nutrients and energy, Randall et al. (11) also revealed an inconsistent relationship between food variety and nutrient density. In most studies on food variety information on relevant dietary composition of specific items consumed is lacking (e.g. low-fat milk (in our study type $\mathrm{A}$ food) vs. whole milk (type $\mathrm{C}$ food) in the dairy group). Our study showed that an increased food variety was accompanied with an increase in the total number of unique food items consumed. Nevertheless, the contribution of different types of foods to the proportion of food items stimulated to be consumed (group A), advised to be consumed in moderation (group B) and advised to be consumed only rarely (group C) remained remarkably stable across the variety categories. The results suggest that subjects in the higher variety groups consumed more foods than persons in the lower ones. The general composition of food did not differ substantially as to nutrients, and no positive relationship with nutrient density could be found. 
The positive trend for vitamin $\mathrm{C}$, and partly for carbohydrates, might be the consequence of differences in the consumption of fruits and vegetables. These major food groups were most frequently missed, whereas the mean consumption (in g/day) of fruits (fresh and prescrved fruits, fruit juices) and salad vegetables was significantly higher in the higher variety categories. Data from the second National Health and Nutrition Examination Survey (NHANES II; 1976-1980) and the Continuing Survey of Food Intakes of Individuals (CSFII; 1985) confirm the role of fruits as limiting factor for meeting the guideline 'Eat a variety of foods', although the proportion of non-users reported in these studies was somewhat higher (10). In contrast with our findings, in the USA dairy products were the second group to be most likely skipped and vegetables the third. Kant et al. (24) reported that $33 \%$ of the US population do not eat from all the major food groups on the survey day. In our study this proportion was $50 \%$ for men and $43 \%$ for women, observed in the lowest variety category. Although food groups were not fully comparable (in our study cream was included in the dairy group, and nuts were not incorporated in the major food groups), the main explanation for the observed discrepancies might be differences in the type of dietary data (one-day recall vs. two-day record) and in eating pattern.

In accordance with Kant et al. (10), we found a positive trend for food variety and level of education and SES. Smoking and skipping of breakfast were inversely related to food variety. This might indicate that food variety can be considered as one of the indicators for a healthy life-style. However, concerning macronutrients (en\%), the average diet of subjects in the higher variety categories was similar to that of the lower categories. In none of the groups diets met entirely the Guidelines for a healthy diet (1). Therefore, all categories of variety should change their food choice in order to reach these goals. For those micronutrients which are recommended in absolute amounts, particularly vitamin $\mathrm{C}$ and iron (only for women), the highest risk for inadequate intake was found among subjects in the lower variety categories. Even in the highest variety group mean iron intake among women was lower than recommended, which confirms that the recommended intake level will be very difficult to achieve. With respect to the comparison with RDAs for micronutricnts there is a fundamental problem when reference values, such as those for bodv weight and energy intake, do not match the actual mean values. Since, for both men and women, the mean intake of energy among the lowest variety category was substantially below the RDA, the requirements of (some) nutrients, and hence the standards to be used, may be lower as well.

In the other categories energy intake was higher than the level considered to be adequate. However, since the requirement depends on physical activity, energy intake is difficult to evaluate as a solitary factor since we did not obtain information on energy expenditure. The results show that subjects belonging to the highest categories of food variety also are the largest eaters. Among men, no differences in BMI according to food variety were observed, whereas among women the lowest variety category had the highest BMI. Since energy intake per $\mathrm{kg}$ body weight has 
been proposed as a proxy for physical activity $(25,26)$, this might indicate that subjects in the higher variety categories were physically more active. The anthropometric data are in line with this interpretation. Among women, obesity was more prevalent in the group with the lowest food variety and the lowest energy intake. Since we excluded subjects with either a physician-prescribed diet or a diet on the subject's own initiative these findings support the observation that obese subjects are more inclined to underreport consumption $(27,28)$. However, the differences between the groups were relatively large so that this explanation probably does not suffice.

Our study was based on a cross-sectional design, which does not allow for cause/effect relationships to be established. Since the association between nutritional knowledge, attitudes and dietary intake is usually weak (29) it is not likely that food variety will be the unique result of a conscious choice. Furthermore, if a person would deliberately select a variety of foods to improve his diet one could expect that there would be a consistent relationship between variety and the quality of the diet. This was not observed in our study. The association of variety with energy intake might point to the tendency to cover a higher energy requirement due to physical activity with a more varied intake. Consumption of more bread, potatoes etc. may cover the extra energy requirement as consumers may find it a nuisance to consume large amounts of one kind of foodstuff.

In conclusion, our results show that the association between variety and dietary intake is characterized mainly by differences in quantity. Inclusion of fruits and vegetables are predictive of a higher variety score. Potatoes, bread, meat were shown to be not discriminative. Since the higher intake levels did not result in a higher incidence of obesity, subjects with a higher variety score may, on average, be more engaged in physical activities. This, in turn, might lead to a higher variety in food selection to cover the higher energy requirement. Our results indicate that realization of the guideline 'Eat a variety of foods' will not automatically lead to a nutrittionally more adequate diet, either because the dietary pattern is too homogeneous to show any differences or because a variety threshold is surpassed above which no residual differences can be found.

\section{References}

1. Netherlands Nutrition Council. Guidelines for a healthy diet. The Hague: Voedingsraad. 1986.

2. Committee on Diet and Health, Food and Nutrition Board. Diet and Health: Implications for Reducing Chronic Disease Risk. Washington. DC: National Academic Press. 1989.

3. Food and Nutrition Board. Recommended Dietary Allowances. 10th ed. Washington, DC: National Academic Press of Sciences. 1989.

4. Department of National Health and Welfare. Nutrition Concepts Evaluation Study. Ottawa, Ontario: Nutrition Education Unit. Health Promotion Directorate, Health Services and Promotion Branch. 1979. 
5. Robson JRK. Wadsworth GR. The health and nutritional status of primitive populations. Ecol Food Nutr 1977;6:187-202.

6. USDA and DHHS (U.S. Department of Agriculture and I'.S. Department of Health and Human Services). Nutrition and Your Health: Dietary Guidelines lur Americans. 2 d ed. Home and Garden Bulletin NO. 232. Washington D. C.: U.S. Governnent Printing Office, 1985.

7. USDA (U.S. Department of Agriculture). Idcas for Better Eating: Menus and Recipes to Make Use of the Dietary Guidelincs. Washington DC: U.S. Government Printing Office, 1981.

8. Anonymous. De Voedingswijzer. Netherlands Bureau for Nutrition Education. The Hague: 1991.

9. Department of National Health and Welfare. Canada's Food Guide: Handbook. Ottawa, Ontario: The Ministry of Health and Welfare. Health Promotion Directorate, 1982.

10. Kant AK, Schatzkin A, Block G, Ziegler RG, Nestle M. Food group intake patterns and associated nutrient profiles of the US population. J Am Diet Assoc 1991;91:1532-1537.

11. Randall E, Nichaman MZ, Contant CF. Diet diversity and nutrient intake. J Am Diet Assoc 1985;85:830-836.

12. Smiciklas-Wright H, Krebs-Smith SM, Krebs-Smith J. Variety in foods. In: What is America eating 1986. Washington D.C.: National Academic Press, 1986:126-140.

13. Hulshof KFAM, Staveren van WA. The Dutch National Food Consumption Survey: design. methods and first results. Food Policy 1991:16:257-60.

14. Netherlands Nutrition Council. Recommended Dietary Allowances 1989 in the Netherlands. The Hague, 1990.

15. NEVO-tabel. Nederlands Voedingsstoffenbestand 1986-1987. The Hague: Voorlichtingsbureau voor de Voeding. 1987.

16. Snedecor GW. Cochran WG. Statistical Methods. 7th ed. Ames Iowa: Iowa State University press, 1982.

17. Garrow JS. Treat obesity seriously. A clinical manual. Edinburgh: Churchill Livingstone, 1981.

18. Dillon WR, Goldstein M. Multivariate analysis; methods and applications. New York: J Wiley \& Sons, 1984.

19. Dixon WJ, Brown MB. Engelsman L. Jenrich RI. BMDP Statistical Software Manual. Berkley: University of California Press. 1990.

20. Guthrie HA, Scheer JC. Validity of a dietary score for assessing nutrient adcuuacy. J Am Diet Assoc 1981;78:240-245.

21. Crochetti AF. Guthrie HA. Alternative eating patterns and the role of age, sex, selection and snacking in nutritional quality. Clin Nutr 1986;5:34-42.

22. Krebs-Smith SM. Smiciklas-Wright H, Guthrie HA. Krebs-Smith J. The effect of variety in food choices on dietary quality. J Am Diet Assoc 1987:87:897-903.

23. Krebs-Smith SM, Clark LD. Validation of a nutrient adequacy score for use with women and children. J Am Diet Assoc 1989;89:775-780, 783.

24. Kant AK, Block G. Schatzkin A, Ziegler RG, Nestle M. Diet diversity in the US population, NHANES II. 1976-1980. J Am Diet Assoc 1991;91:1526-1531.

25. Sopko G, Jacobs R. Taylor HL. Dietary measurements and physical activity. Am J Epidemiol 1984;120:900-911.

26. Gordon T, Fisher M. Rifkind BM. Some difficulties inherent in the interpretation of dietary data from free-living populations. Am J Clin Nutr 1984:39:152-156.

27. Prentice AM. Black AE. Coward WA et al. High levels of energy expenditure in obese women. Br Med J 1986:292:983-987.

28. Livingstone MBE. Prentice AM. Strain JJ et al. Accuracy of weighed records in studies of diet and health. Br Med J 1990;300:708-712.

29. Axelson ML. A meta-analysis of food- and nutrition related research. J Nutr Educ $1985: 17: 51-54$. 


\section{Annex 7.1. List of food groups and some examples of foodstuffs included}
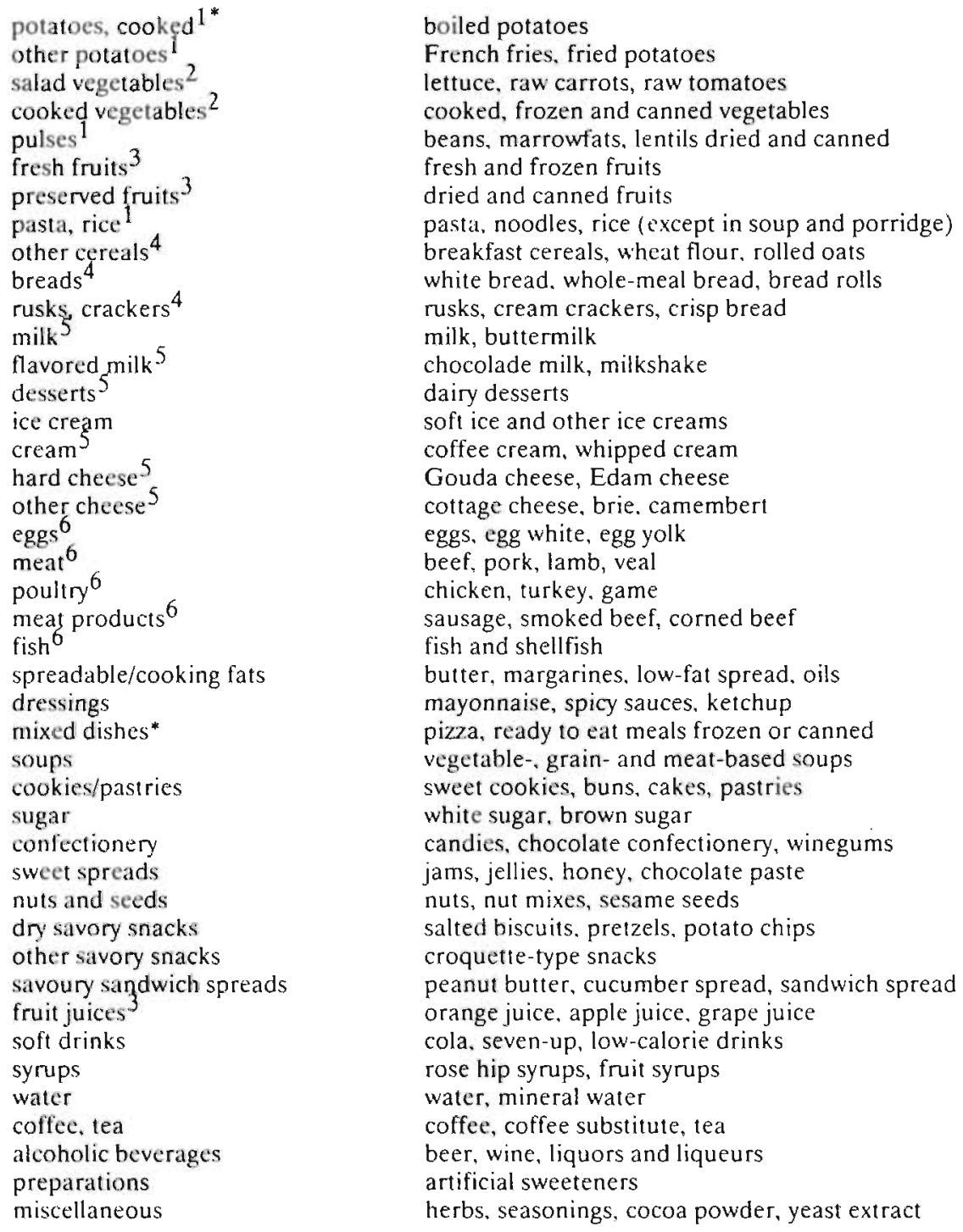

* Belonging to one of the major food groups: 1) potatoes, 2) vegetables, 3) fruits, 4) cereals, 5) dairy. 6) meat.

* on the basis of their ingredients assigned to the most appropriate groups. 
Annex 7.2. Criteria used to characterize foods according to the Netherlands Bureau of Nutrition Education. ${ }^{1}$

\section{(Relatively) carbohydrate-rich product \\ Potatoes, pulses, pasta, rice, breads, cereals \\ A $>40 \mathrm{en} \%$ starch \\ $>14 \mathrm{~g} / 4.2 \mathrm{MJ}$ dietary fibre \\ $<30 \mathrm{en} \%$ fat \\ B $>40$ en\% starch \\ $30-\leq 40 \mathrm{en} \%$ fat \\ C remaining products}

Biscuits, pastry, confectionery, sweet snacks
A $<30 \mathrm{en} \%$ fat
B $30-\leq 40$ en\% fat
C remaining products

Sweet spreads and sugar
A $<30 \mathrm{en} \%$ fat
B $\quad 30-\leq 40 \mathrm{en} \%$ fat
C remaining products

(Relatively) protein-rich products

\section{Milk and milk products}

A $<25 \mathrm{en} \%$ fat

B $25-\leq 35$ en\% fat

C remaining products

Cheese, meat, meat products, poultry, eggs, fish, soya products, meat snacks
A $<50$ en $\%$ fat
B $\quad 50-\leq 70$ en $\%$ fat
C remaining products

\section{(Relatively) vitamin C-rich products}

Vegetables and fruits
A $>30 \mathrm{mg} / 4.2 \mathrm{MJ}$ vitamin C
$14 \mathrm{~g} / 4.2 \mathrm{MJ}$ dietary fibre
$<30$ en\% fat
B $\quad$ I-30 mg/4,2 MJ vitamin C
C remaining products

(Relatively) fat-rich products

\section{Spreadable fats}
A $<40 \%$ fat
$<25$ en $\%$ SFA $^{\prime}$
B $>40 \%$ fat
$<25$ en $\%$ SFA or $<40 \%$ fat
$<40 \%$ fat
$>25$ en $\%$ SFA

C remaining products

Cooking fats
A $\quad<.25$ en $\%$ SFA
B $25-\leq 40$ en $\%$ SFA
C remaining products

Dressings

A $<10 \%$ fatoil

B $\quad 10-40 \%$ fat/oil

C remaining products

Nurs and savoury snacks
A $<50$ en $\%$ fat
B $\quad 50-\leq 70 \mathrm{en} \%$ fat
C remaining products

1 en\%, expressed as percentage of total energy: SFA, saturated fatry acids; A, foods to be stimulated; E, acceptable foods; $C$, foods to be consumed only occasionally. 



\section{General discussion}

The aim of the studies described in this thesis was to investigate and to evaluate the dietary pattern of the Dutch population and to identify risk groups. Furthermore, the impact of several life-style and sociodemographic factors and the interdependence with dietary patterns were studied. The first Dutch National Food Consumption Survey (DNFCS) was used as data base.

\section{Methodological considerations}

In assessing dietary intake, measurement errors may occur due to the design of the study, data collection, data handling and data analysis, and consequently may affect the validity and reliability of the results. Moreover, confounding factors may distort the picture and hamper a proper interpretation of the results. Therefore, sources of potential error, potential confounders and measures taken to reduce these errors will be considered here.

\section{Subject selection}

Achieving sufficient response rates is a major issue in nutritional surveillance. In comparison with other nutritional surveys on a national level (1-9), the first DNFCS has a relatively low non-response rate. Subjects of the DNFCS were members of a household panel (the so-called script panel) of the marketing research organization AGB Attwood. This panel was established in 1977; in the early 1980 s the response rate among the newly recruited households was $40-42 \%$ (A.M. Dijs, AGB Attwood, personal communication). To reflect a representative picture of the noninstutionalized households in the Netherlands, the panel is regularly controlled on the most important socio-economic and demographic characteristics (region, socioeconomic status (SES), age of the housekeeper, household size, age of the youngest household member) with the so-called mini census as the reference population (10). Every year, on the average $15 \%$ of the households 'leaves' the panel. To fill up this gap new households are recruited such that the differences in distribution of the forementioned characteristics between the reference population and the actual panel are taken into account. From the script panel the DNFCS sample was selected using region, urbanization degree, age of the housekeeper, household composition and household size as target variables. Both at the household level and at the individual level differences in characteristics of the DNFCS sample with the mini census of 1986 were marginal (10). To get an impression of the external validity of the sample 
the population of the DNFCS was compared with 1986/1987 data of the Central Bureau for Statistics (11); differences according to age and sex distributions appeared to be small (mean proportional differences according to 5 -year age categories 1.0 , range 0.1 to 3.9 , among men and 0.6 , range 0.0 to 2.5 , among women). These factors have a substantial effect on dietary intake variables. The impact on diet of the other controlling variables was limited, whereas variation in the data was substantial. Other, still unknown, factors may explain this variation. Knowledge of these factors is of importance, especially with respect to a correct representation in the sample. However, for the time being we have to base our assessment of the representativeness of the sample on the more traditional sociodemographic variables.

In recruiting households the dietitians had to distribute them equally and randomly over all days of the week. However, when the housekeeper refused to cooperate on the days originally planned, she/he was asked to participate on two other consecutive days within the next two weeks. This procedure reduced (selective) non-response but might have introduced some sample bias on specific days when there existed interactions between preference for days of the week and socioeconomic and demographic characteristics of the households. However, in the final sample no significant differences were found in the proportion of week days and weekend days according to socio-economic and demographic variables.

As discussed in Chapter 3, recruitment from an existing panel has some major advantages. On the other hand, as discussed above, this way of sampling may have introduced some bias. However, in our opinion, the data presented can be considered representative of the Dutch population aged 1-85 living in households with a housekeeper younger than 75 years. Excluded were households whose members could not speak or read Dutch.

\section{Data collection}

Problems associated with measuring dietary intake in individuals and in populations have been extensively reviewed in numerous papers and manuals (12-19).

In the DNFCS much attention was given to interviewers' qualification, training and supervision to avoid interviewer bias. Interviewers were trained dietitians and special training and retraining courses provided standardized information on the study. Reference manuals $(20,21)$ were used to promote consistency in performance over time and among interviewers.

Although a weighed record method is generally considered the most accurate method for dietary assessment (22), in the DNFCS estimated records (quantities basicd on household measures) were used. This method is less prone to sample bias and is rcgarded as a satisfying alternative in assessing amounts consumed (23). Moreover, to improve the accuracy of the estimates, the interviewer weighed common household measures and food regularly reported (e.g. amounts of spreadable fats, size of a spoon of sugar). These weighed figures were used for the 
calculations. Systematic errors due to incorrect estimations of amounts of food eaten are thus not very likely.

In studies on food consumption dietary habits may be changed as a consequence of the study itself (24). It may be expected that a longer period of record keeping leads to a higher response burden and to a greater chance of changing diets. The pilot study of the DNFCS, using a three-day dietary record, indicated that subjects were inclined to simplify their diet, particularly on the third day. Therefore, in the DNFCS two record days were chosen.

Our results as to the consumption of foods, the intake of energy and nutrients, body weight and height, alcohol intake and smoking status may be affected by underand overreporting. These flaws are well documented (25-41), and no simple solutions to counteract these errors are available. However, the major effect will be on the absolute level of the various variables, whereas comparisons among subgroups will be less affected by reporting bias $(40,42,44-46)$. The most likely effect will be smaller differences among subgroups resulting in a lower sensitivity of data analysis.

\section{Data handling}

Coding errors may arise when food items or the amounts of foods are incorrectly coded. In the DNFCS, quality measures to limit these errors were such that coding errors hardly contributed to errors in data handling.

To convert food consumption data into nutrient intake, a computerized version (1986-1987) of the Dutch food composition table (47) was used. This table is not complete for all foods and nutrients. However, since previous studies have indicated that these effects are minimal $(48,49)$, the data presented are not likely to be substantially biased due to incompleteness of the food composition table. However, it is important to realize that food table values are based on rather ideal food preparation conditions which are not always encountered in practice $(50,51)$. Therefore, the intake of some nutrients will be somewhat overestimated. On the other hand, we were not able to quantify nutrient intake from supplements. Since the highest proportion of supplement users was observed in groups with a higher SES, it is especially in these groups that the intake of certain micronutrients will be underestimated. The intake of most micronutrients tended to be higher already among higher SES groups (Chapter 5), and therefore it is unlikely that the exclusion of the nutrient intake from supplements has affected our conclusions regarding risk groups.

In brief, we conclude that it is not likely that the presented data have been affected substantially and/or systematically by data handling. 


\section{Data analysis and interpretation}

If measurement errors are reduced the sources of true variability may still affect the interpretation of the data. Dietary intake varies both among individuals (interindividual or between-person variation) and within one individual from day to day (intraindividual or within-person variation). Differences in food and nutrient intake according to age and sex represent sources of variation that can contribute to the estimate of between-person variation. For most nutrients between-person variation in nutrient intake is usually smaller than within-person variation (52-58). As a result, mean nutrient intake in a group can generally be assessed more precisely than individual intake, provided the sample size is large enough. The results presented in this thesis refer to average intake figures. Almost all groups comprised more than 100 subjects and the representativeness of the survey sample can be considered as adequate (see above).

The effects of day of the week on the assessment of dietary intake in individuals and groups are well recognized $(53,56,59,60)$. The DNFCS was distributed equally over the seven days of the week and over a whole year, but holidays were excluded. As a consequence of this exclusion, especially within-person variation might have been underestimated somewhat. Our results confirm that there are differences in dietary intake among days of the week (Chapters 6 and 7).

In studying the effect of a variable of interest, for instance SES, on dietary intake, other variables such as age, gender and day of the week can be considered as potential confounders. Control of confounding in data analysis can be achieved either by stratification or by multivariate analysis (61). Our conclusions as to differences among subgroups are not likely to be affected by these confounders, since in the statistical analysis differences due to age, sex, week and weekend days were taken into account (Chapters 4-7).

In comparing dietary data with guidelines for a healthy diet, proportions of the population meeting the guidelines were calculated. Supported by other studies $(8,62-65)$, our results indicate that our estimates are not severely biased by withinperson variation.

In summary, it seems not likely that recruitment, data collection, data handling and data analysis have introduced major systematic errors. Data of the DNFCS thus provide a reliable and valid source of information for evaluation of dietary intake in the Dutch population and for risk group assessment.

\section{Aspects of nutritional surveillance in the Netherlands and other industrialized countries}

Several industrialized countries have performed individual nutritional surveys based on national samples. These surveys differ in coverage of population, dietary method, nutrition- and health-related indicators, etc. $(1-9,66,67)$. In line with the 
recommendations of the Netherlands Nutrition Council (68), the Dutch Nutrition Surveillance System consists of two components (the collection of 1) dietary data and 2) indices of nutritional health status; see Chapter 3 ). Such a two-tier system has the advantage of being more distinctive and can thus be time- and cost-effective. Until now, only dietary data are collected. However, food consumption data do not allow for definite conclusions about the prevalence of deficiencies within population groups, since a low intake of a nutrient may render deficiency highly probable, but rarely certain. Therefore, investigations into nutritional health status are always needed to confirm the results for groups identified as being at risk for nutrient inadequacies (69). Conclusions regarding risk groups in the DNFCS have a weaker basis than those based on surveys that assess also the health status of the same individuals, for example the elderly (70).

In the DNFCS, with subjects recruited from a panel, the non-response rate was low in comparison with other national studies (Chapter 2). In most other surveys other information was gathered in addition to biochemical and clinical data (Table 2.1). This offers the opportunity to study more diverse interrelationships, but gives also a higher response burden, which will influence the response rate negatively.

So far, it seems that only in the USA, the UK and the Netherlands national surveys on the individual level will be repeated, which will offer the opportunity of trend analysis.

\section{The Dutch diet and the Guidelines for a healthy diet}

Guidelines for a healthy diet and RDAs are normative figures and provide thus standards commonly used to evaluate the quality of diets of population groups $(56,71)$. Compared to the Guidelines for a healthy diet of the Netherlands Nutrition Council (68), the average intake of fat (especially of saturated fatty acids) was high, whereas the intake of total carbohydrates (particularly polysaccharides) and dietary fibre was low (Chapter 4).

To obtain more information on the percentage of subjects with dietary habits meeting the guidelines, intake distributions were studied. To estimate prevalence values, cut-off points in conformity with the guidelines were used. When this approach is used the figures should be interpreted with great care. According to Beaton (72), nutrient intake estimates must refer to the same time frame as the number of days used as the physiological basis for the requirements. In the Netherlands no indications are available presently as to the number of days an assessment of food consumption should be based on to evaluate the adequacy. Since the guidelines for the contribution of macronutrients to energy intake are largely based on the association with chronic diseases, it is the usual intake level that matters. Theoretically, it is possible to adjust the observed distribution of intake to obtain a distribution that approximates more closely usual intake (73). However, it is questionable whether, in this case, the adjusted prevalence values are more accurate than the unadjusted ones. An adjustment based on two consecutive days may lead to 
an overestimation of within-person variance. Furthermore, the within-person variance components are lower when the intake level is lower $(54,74)$. Compared with other studies in which the usual diet was assessed, our unadjusted prevalence estimates were in better agreement with the values derived from the habitual consumption distribution than were the adjusted ones $(8,62-65)$. Our findings indicate that prevalence values must be interpreted with caution, but we assume nonetheless that our unadjusted prevalence estimates are more realistic.

In the Netherlands, the proportion of adults having a diet with less than $35 \%$ of energy derived from fat was low $(<25 \%)$, whereas $5 \%$ at most met the Dutch guideline for saturated fatty acids. Compared with the adult population, the proportion of children using a diet in accordance with the guideline for fat was higher, and with those for mono- and disaccharides and dietary fibre (much) lower (Table 4.4). In fact, the results for adults may be flattered, since fat intake (en\%) and alcohol were inversely associated. In contrast to the UK (74), the Dutch guidelines do not explicitly state whether energy-related recommendations (as presented for fat, carbohydrates and protein) include energy derived from alcohol or not, which hampers a proper evaluation of the Dutch diet.

For a major part of the Dutch population the diet is not very well balanced. The finding that only a very small part of the population had a diet in agreement with all five dietary goals demonstrates how difficult it is to realize a healthy diet in practice (Table 4.4). For prevention-oriented nutritional programmes, the diets of those already eating in accordance with the fat guideline may provide valuable information. These persons consumed food groups with a major contribution to fat intake in lower amounts, and within food groups more low-fat products were selected. This means that consumers have to become familiar with the dietary composition of foods. Knowledge about the fat content of foods varied strongly in the Dutch population (75): milk products scored well, cakes and meat fairly well, but sweet or savoury snacks very poorly. An evaluation study of the national 'Let op Vet' (Fat Watch) campaign showed that a considerable proportion of the respondents has a fair knowledge on food. However, questions related to the fat content of butter and several types of margarine scored poorly, and about $60 \%$ of the respondents found it difficult to apply this knowledge in practice (76). Therefore, labelling of nutrient values, and recipes for palatable meals containing less fat are considered to be essential vehicles to encourage the consumer to make informed food choices and to meet the (fat) guidelines more easily $(68,77)$.

\section{'Eat a variety of foods' and an adequate diet}

As in most industrialized countries, food supply is abundant in the Netherlands. The marketing strategies of the food industry have increased the number of different food products tremendously. Exposure to new or exotic foods has also increased due to migration, holidays and travelling. All these facts inevitably have increased the variety of food consumption patterns in the Dutch population. An increased variety 
in food intake is supposed to improve nutritional adequacy $(68,78,79)$. As in some other studies $(80,81)$, our results presented in Chapter 7 indicate that among adults aged 22-49, a higher degree of food variety is generally associated with a higher nutrient intake and a higher energy intake, but no consistent association between food variety and nutrient density as quality characteristic was observed. Recently, Murphy et al. (82) found that, relative to demographic and economic characturistics, energy intake is the best single predictor of the adequacy of the diet of an American adult, but adequacy was not defined as nutrient density. Another determinant wis the consumption of fruits and vegetables (Chapter 7), which might have implications for nutrition education. In our study food variety was positively associated with energy consumption, without resulting in a higher incidence of obesity among the larger eaters. Although the absence of information on physical activity hampers the interpretation, the association found presumes a higher physical activity among subjects in the higher variety groups. Since a higher degree of food variety was also associated with other more desirable life-style variables. this might indicate that subjects belonging to those categories have a more health-conscious behaviour. However, the selection of foods in all food variety categories was not optimal. a higher food variety was being associated with a higher use of all kinds of foods. In none of the food variety groups a prudent diet was observed, whereas particularly in the lower food variety categories the intake of vitamin $C$ and retinol gives cause for concern. Good sources of these nutrients are vegetables and fruits. In agreement with findings of Krebs-Smith et al. (83), this might indicate that, if food intake is limited, choices should be varied even more.

Therefore, guidance in selecting nutritionally adequate diets should be targeted to all adults (and most likely to the whole population), with special attention for those with a low energy intake and those who are physically most inaclive. These categories are most likely overrepresented in the low SES groups. The use of vegetables and fruits should be stressed especially in these groups.

\section{Identifying groups with (un)desirable life-style characteristics}

For risk group identification and decisions on whether recommendations for changes in dietary intake and other life-style variables should be targeted on the population at large or on high-risk groups, information is needed on existing differences in lifestyle variables among population groups. The World Health Organization has described life-style as 'a cluster of closely interrelated behaviour patterns that depend on social and economic condition, education, age and other factors' (84).

Tobacco use, alcohol consumption, use of food supplements and food habits as components of life-style were studied in relation to socio-demographic variables. SES was based on educational level, occupation and occupational position, the highest level in a household being chosen as the level for the individual household members. Generally, among subjects with a lower SES more unfavourable life-style factors were observed. An exception was the relatively high alcohol consumption in 
the higher SES groups. Both on week days and weekend days the proportion of alcohol users was highest among subjects with a higher SES. Especially on weekend days the prevalence of the use of more than 3 alcoholic drinks per day was highest among men and women in the high SES groups. However, the observed differences in mean intake of alcohol and other nutrients according to SES were of the same magnitude irrespective whether they were adjusted for effects of week and weekend days. Overall dietary intake tended to be closer to dietary recommendations in higher SES groups (Chapter 5). This is in agreement with other dietary studies (85-87). However, in none of the groups studied a really prudent diet was observed and, in contrast to studies in other countries, the differences among groups were small and not always relevant for health risks. Fat intake (expressed as a percentage of energy intake) was slightly higher among subjects with a low SES, but alcohol may have diluted fat consumption in the higher SES groups. Without the energy derived from alcohol, among women differences in total fat intake disappeared.

Segmentation of subgroups on other sociodemographic variables, such as region, degree of urbanization and household size only revealed relatively small differences $(88,89)$.

The use of an indicator of SES based on several variables is subject to criticism and the use of education and occupation and, possibly, income as separate indicators has recently been recommended (90). In the DNFCS information on occupation was only available as an integrated SES variable and as a characteristic of employment (e.g. full-time job, part-time job, unemployed, retired or temporarily disabled). Among subjects aged 19 and over a lower SES was associated with a higher proportion of unemployed subjects and those disabled to work. Information on income was not available. One of the problems in using an integrated SES variable is the risk of misclassification. For instance, the values of occupation might have a contemporary character. Despite the limitations and as a consequence of the limited information available in our study we preferred to use the integrated SES variable rather than education only. As a characteristic of the household, the former was available for all subjects of the household, and SES might reflect the economic position of subjects in a better way. Furthermore, the size of the subsamples was often too small for a further refinement using other demographic variables.

Our study in the Netherlands in 1987-1988 confirms the notion that 'classic' socio-economic and demographic factors are not very predictive with regard to food choices (91). Nutritional health risks seem to be dispersed throughout the Dutch adult population. Since Kottke (92) found that population-based recommendations are more effective than measures targeted at special SES groups, for the time being a population-based strategy seems to be the most appropriate approach. However, our results provide information that allows for tailoring the nutritional message to specific groups. 


\section{Identifying groups with clusters of (un)favourable dietary factors}

Unfavourable life-style factors have been reported to be interrelated and clusters of these factors may have a greater (albeit not necessarily cumulative) impact on health than a single factor by itself $(93,94)$. For instance, Belloc and Breslow (95) found associations between smoking, physical activity, alcohol consumption, body weight, hours of sleep, (skipping) breakfast, snacks between meals as indicators of life-style on one hand and health risks on the other. An (un)balanced diet often acts in combination with other elements of an (un)healthy life-style (96). Due to the dietary composition of foods and the eating pattern a diet may be unbalanced for more than one nutrient. By applying cluster analysis, the total diet can be examined simultaneously, and interrelationships with other life-style factors can be studied using the clusters as a starting point.

Until now, most cluster analyses based on dietary surveys used food items as cluster criteria (97-102). However, as shown in Chapter 6, the use of nutrients as criteria may lead to the identification of relevant groups with substantial differences in mean intake figures. The contrasts were much larger and more relevant than those among SES groups, using a priori segmentation (Chapter 5). More than half of the population had diets that departed substantially from the Guidelines for a healthy diet. In some of these clusters other aspects connected with unfavourable life-style were found. For instance, in the clusters with the highest alcohol consumption the proportion of smokers and the proportion of subjects with less than seven sleeping hours at night were also highest, which is in line with results of other studies $(94,95,103)$. The traditional socio-economic and demographic characteristics did not discriminate very well. In some clusters a relationship with SES and/or education was observed, but the association of these factors with nutritional quality of the diet was not consistent. Unfortunately, in the DNFCS the number of life-style characteristics measured was limited. The redefinition of social roles within the household, the rise of 'multi-earner' households, new priorities in the spending of (leisure) time and many other factors might have an important impact on life-style and food choice (104). Several studies suggest that nutritional knowledge and nutrition/health-related attitudes are more closely related to dietary intake (105-109). The lack of information on physical activity, attitudes and nutritional knowledge, and on other socio-cultural indicators might have hampered proper interpretation (Chapters 4-7). We are not able yet to trace sufficiently large segments with a deviant dietary intake pattern efficiently in order to produce diversified recommendations.

\section{Conclusions and recommendations}

The results of the studies described in this thesis lead to the following conclusions. 
- The sample of the DNFCS can be considered representative of the Dutch population aged 1-85, living in households with a housekeeper younger than 75 years, excluding households whose members cannot speak or read Dutch.

- Although surveys across countries conducted within the framework of nutritional surveillance differ in several aspects, the Dutch system is, generally speaking, in line with the dietary part of systems in other industrialized countries.

- The Dutch diet is not in accordance with the guidelines for a healthy diet. The average intake of fat (especially saturated fatty acids) is too high, whereas the intake of carbohydrates (particularly polysaccharides) and dietary fibre is too low. Only a very small part of the population $(<1 \%)$ uses a diet in agreement with all five dietary goals studied.

- Alcohol intake and fat intake (as a percentage of energy intake) are inversely related. For a proper evaluation it is recommended that guidelines state explicitly whether alcohol should be included in the calculation of the energy contribution by energy-related nutrients.

- Our study based on two consecutive record days resulted in ambiguous conclusions as to the usefulnes of adjustment for within-person variability. More studies are needed to investigate the effect of adjustment on the distribution of nutrients based on records obtained during more than two consecutive and nonconsecutive days.

- Eating a variety of food does not automatically lead to a more adequate diet.

- Edible fats, meat (products), milk (products), cheese, savoury snacks and biscuits \& pastry are important fat sources in the Dutch diet. To achieve a lowfat diet more attention for these food groups, and especially for substitution by low-fat varieties within these groups, is needed. Moreover, the consumption of food groups with a low fat and high polysaccharide content has to be stimulated.

- Dietary intake of subjects in higher socio-economic groups tends to be somewhat closer to dietary recommendations. However, differences according to socioeconomic status are rather small. Since the nutritional risks were found to be dispersed throughout the various groups there is no solid basis for nutritional messages targeted at special groups.

- Indicators of an unfavourable life-style, such as smoking and obesity, are generally most prevalent among lower socio-economic groups. The use of more than three alcoholic drinks per day was more common in the higher social class than in the lower social class.

- Using cluster analysis based on nutrient intake characteristics, it is possible to identify clusters in the adult population with substantial differences in (un)favourable dietary factors. However, with the aid of traditional risk characteristics these clusters cannot be identified adequately.

- To provide a better segmentation of the population, further study is warranted to determine whether there are indices of life-style and/or sociodemographic characteristics that are more sensitive than the 'classic' ones. 


\section{References}

1. Health and Welfare Canada. Nutrition Canada National Survey. Ottawa: Supply and services. 1973.

2. Cashel K, English R. Bennett S, Berzins J, Brown G, Magnus P. National dietary survey of adults: 1983. No. 1: Foods consumed. Canberra: Australian Government Publishing Service, 1983.

3.. Goncalves Ferreira FA, Amorim Cruz JA, Rego de Aquiar LA, Martins I, Carlota Mano M, Ascensao Dantas M. Inquérito alimentar national 1980 (1.a Parte).

Revista do Centro de Estudos de Nutricão 1985;9: 5-124.

4. English R, Cashel K. Lewis J, Bennett S, Berzins J, Penm R. National dietary survey of schoolchildren (aged 10-15 years): 1985. No. 1: Foods consumed. Canberra: Australian Government Publishing Service, 1988.

5. Kornitzer M. Dramaix M. The Belgian interuniversity research on Nutrition and Health (BIRNH): General introduction. Acta Cardiologica 1989;44: 89-99.

6. Life Science Research Office FASEB. Nutrition Monitoring in the United States. An updating report in nutrition monitoring. Hyattsville: DHHS Publication No. (PHS) $89-1255,989$.

7. $\quad$ Becker W. Kostvanornai södra Sverige-resultat fran en provundersökning. Văr Föda 1990;6: 322--333.

8. Gregory J. Foster K. Tyler H. Wiseman M. The dietary and nutritional survey of British Adults. London: HSMO, 1990.

9. Heseker H. Adolf T, Eberhardt W. Hartmann S. Herwig A. Kübler W, Matiaske B, Mock KJ, Schneider R, Zipp A. Lebensmittel- und Nährstoffaufnahme Erwachsener in der Bundesrepublik Deutschland. VERA-Schriftenreihe, Band III, Niederkleen: Wissenschaftlicher Fachverlag Dr Fleck, 1992.

10. Beschrijvend rapport Voedselconsumptiepeiling 1987/1988. Dongen: AGB Attwood, 1988.

11. CBS. Bevolkingsprognose voor Nederland. 1988-2050. Statistisch Bulletin 1988;44:5

12. Pekkarinen M. Methodology in the collcetion of food consumption data. World Rev Nutr Diet 1970;12: 145-171.

13. Marr JW. Individual dietary surveys: purposes and methods. World Rev Nutr Die1 1971;13: 105-164.

14. Bazzarre T, Myers $M$. The collection of food intake data in cancer epidemiology studies. Nutr Cancer 1983:5: 201-214.

15. Keys A. Dietary survey methods. In: Levy R. Rifkind B, Dennis B. Ernst N (eds): Nutrition, Lipids and Coronary Heart Disease. New York: Raven Press, 1979: 1-23.

16. Block $\mathrm{G}$. A review of validations of dietary assessment methods. Am J Epidemiol 1982:115: 491-505.

17. Bingham SA. The dietary assessment of individuals; methods, accuracy, new techniques and recommendations. Nutr Abstr Rev (Series A) 1987:57: 705-742.

18. Cameron ME. Van Staveren WA (eds): Manual on methodology for food consumption studies. New York: Oxford University Press, 1988.

19. Gibson RS. Principles of nutritional assessment. New York: Oxford University Press, 1990.

20. Westenbrink S, Brants HAM, Hulshof KFAM, Schneijder P. Maten, gewichten en codenummers 1987. Zeist: TNO-report nr V 84.342. 1987.

21. Hulshof KFAM, Van Staveren WA. Instructies voor de enquetrices betrokken bij de landelijke peiling van de Voedselconsumptie 1987. Beschrijvend rapport Voedselconsumptiepeiling 1987'1988. Dongen: AGB Attwood, 1988.

22. Bingham SA. Nelson M, Paul AA. Haraldsdöttir J, Løken EB and Van Staveren WA. Methods for data collection at an individual level. In: Cameron ME and Van Staveren WA (eds.). Manual on methodology for food consumption studies. New York: Oxford 
University Press, 1988: 53-106.

23. Nettleton PA, Day KC, Nelsorr M. A comparison of nutrient intakes within families. assessed by household measures and the semiweighed method. J Hum Nutr 1980;34: 349-354.

24. Bingham SA. Limitations of the various methods for collecting dietary intake data. Ann Nuts Metab 1991;35: 117-127.

25. Pernanen K. Validity of survey data on alcohol use. In: Gibbens RJ (eds) Research in Alcohol and Drug Pioblems, Vol 1. New Yoik: J Wiley, 1974.

26. Allen P, Lundl B. Westing H. Carbon monoxide blood levels and reported cessation of smoking. Psychopharmacology 1976;49: 263-269.

27. Charney EG, Goodman HC, McBride M, Lyon B. Prat R. Childhood antecedents of adult obesity: Do chubby infants become obese adults? N Engl J Med 1976:295: 6-9.

28. Silett RW. Wilson MB, Malcolm RE, Ball KP. Deception among smokers. Br Med J $1978: 2: 1185-1186$.

29. Wing R.R. Epstein L.H. Ossip DJ, LaPorte NE. Reliability and validity of self-report and observers' estimates of relative weight. Addict Behaviors 1979:4: 133-140.

30. Gillies PA, Wilcox B, Coates C, Kristmundsdotir F, Reid DJ. Use of objective measurements in validation of self-reported smoking in children aged 10 and 11 years: saliva: thiocyanate. J Epidemiol and Commun Health 1982;36: 205-208.

31. Pirie P, Jacabs D. Jeffrey R, Hannan P. Distortion in self-reported height and weight data. J Am Diet Assoc 1981:78: 601-606.

32. Kranzlet NJ. Mullen BJ. Schutz HG, Grivetti LE, Holden CA, Meiselman HL. Validity of telephoned diet recalls and records for assessment of individual food intake. Am J Clin Nutr 1982;36: 1234-1242.

33. Midanik $\mathrm{L}$. The validity of self-reported alcohol consumption and alcohol problems: a literature review. Biritish J Addict 1982;77: 357-382.

34. Multiple Risk Factor Intervention Trial (MRFIT) Research Group: Multiple Risk Factor Intervention Trial: Risk Factors changes and mortality results. J Am Med Assoc 1982:248: 1465-1477.

35. Palta M. Prineas RJ, Hannan P. Comparison of self-reported and measured height and weight. Am J Epidemiol 1982:1 15: 22:3-230.

36. Stewart AL. The reliability and validity of self-reported weight and height. J Chron Dis 1982:35: 295-305.

37. Vesey CJ. Salojee Y. Cole PV. Russell MAH. Blood carboxyhaemoglobin, plasma thiocyanate and cigarette consumption: Implications for epidemiological studies in smokers. Br Med J 1982:284: 1516-1518.

38. Guthrie HA. Selection and quantification of typical food portions by young adults. J Am Diet Assoc 1984:84: 1440-1444.

39. Jarvis MJ. Tunstall-Pedoe H. Feyerabend C. Yesey C. Saloojee Y. Comparison of tests used to distinguish smokers from nonsmokers. Am J Public Health 1987;77: 1435-1438.

40. Rowland ML. Self-reported weight and height. Am J Clin Nutr 1990:52: 1125-1133.

41. Schoeller DA. How accurate is self-reported dietary energy intake? Nutr Rev 1990:48: 373-379.

42. Mertz W. Tsui JC. Judd JT, Reiser S, Hallfrisch J, Morris ER, Steele PD, Lashicy E. What are people really eating? The relation between energy intake derived from estimated diet records and intake determined to maintain body weight. J Clin Nutr 1991:54:291-295.

43. Goran MI, Poehlman ET. Total energy expenditure and energy requirements in healthy elderly persons. Metabolism 1992:41: 744-753.

44. Stunkard AJ. Albaum JM. The accuracy of self-reported weights. Am J Clin Nutr 1981:3: 1593-1599.

45. Knibbe RA, Drop MJ, Van Reek J, Saenger G. The development of alcohol consumption in the Netherlands: 1958-1981. Br J Addict 1985;80:4 1.1-419. 
46. Smith GT, Hohlstein LA, Atlas JG. Accuracy of self-reported weight: covariation with binger or restrainer status and eating disorder symptomatology. Addict. Behaviors 1992:17: 1-8.

47. NEVO-tabel. Nederlands Voedingsstoffenbestand 1986-1987. Voorlichtingsbureau voor de Voeding. The Hague 1987.

48. Löwik MRH, Van Poppel G, Wedel M, Van den Berg H, Schrijver J.

Dependence of vitamin B6 status assessment on alcohol intake among elderly men and women (Dutch Nutrition Surveillance System). J Nutr 1990:120: 1344-1351.

49. Löwik MRH, Wedel M, Kok FJ, Odink J, Westenbrink S, Meulmeester JF. Nutrition and serum cholesterol levels among elderly men and women (Dutch Nutrition Surveillance System). J Gerontol 1991:46: m23-m28.

50. Arab L. Analyses, presentation, and interpretation of results. In: Cameron ME. Van Staveren WA (eds): Manual on methodology for food consumption studies. New York: Oxford University Press, 1988; 145-169.

51. Westenbrink S, Löwik MRH, Hulshof KFAM, Aarnink E. Kistemaker C. Effect of household size on nutritional patterns among the Dutch elderly. J Am Diet Assoc 1989;89: 793-799.

52. Liu K. Stamler J, Dyer A, McKeever J, McKeever P. Statistical methods to assess and minimize the role of intra-individual variability in obscuring the relationship between dietary lipids and serum cholesterol. J Chron Dis 1978:31:399-418.

53. Beaton GH, Milner J, McGuire V. Feather TE. Little JA. Source of variance in 24hour dietary recall data: implications for nutrition study design and interpretation. Carbohydrate sources, vitamins. and minerals. Am J Clin Nutr 1979:32: 2546-2559.

54. Hunt WC. Leonard AG, Garry PJ. Goodwin JS. Components of variance in dietary data for an elderly population. Nutr Res 1983:3: 433-444.

55. Borrelli R. Cole TH. DiBiase G. Contaldo F. Some statistical considerations on dietary assessment methods. Eur J Clin Nutr 1989;43: 453-463.

56. Gibson RS, Gibson IL, Kitching J. A study of inter- and intrasubject variability in seven-day weighed dietary intakes with particular emphasis on trace elements. Biol Trace Elem Res 1985:8: 79-91.

57. Nelson M. Black Ae. Morris JA, Cole TJ. Between- and within-subject variation in nutrient intake from infancy to old age: estimating the number of days required to rank dietary intakes with desired precision. Am J Clin Nutr 1989:50: 155-167.

58. Hartman AM. Brown CC. Palmgren J, Pietinen P. Verkasalo M. Myer D. Virtamo J. Variability in nutrient and food intakes among older middle-aged men - implications for design of epidemiologic and validation studies using food recording. Am J Epidemiol 1990;132: 999-1012.

59. Richard $\mathrm{L}$. Roberge AG. Comparison of caloric and nutrient intake in adults during week and week-end days. Nutr Res 1982;2:661-668.

60. Van Staveren WA. Hautvast JGAJ. Katan MB, Van Montfort MAJ, Van Oosten-van Goes HGC. Dietary fibre consumption in an adult Dutch population. J Am Diet Assoc 1982:80: 324-330.

61. Rothman KJ. Modern Epidemiology. Boston: Little. Brown and Co, 1986.

62. Löwik MRH. Westenbrink S. Hulshof KFAM. Kistemaker C. Hermus R.JJ. Nutrition and aging: Dietary intake of 'apparently healthy' elderly (Dutch Nutrition Surveillance System). J Am Coll Nutr 1989:9: 347-356.

63. Nelson M. Nutritional goals from COMA and NACNE: How can they be achieved. Hum Nutr Appl Nutr 1985:39A: 456-464.

64. Thomson M. Fulton M. Wood DA, Brown S, Elton RA, Birthwhistle A, Oliver MF. A comparison of the nutrient intake of some Scotsmen with dietary recommendations. Hum Nutr Appl Nutr 1985:39A: 443-445.

65. Winkler G. Döring A. Keil U. Selected nutrient intakes of middle-aged men in southern Germany: results from the WHO MONICA Augsburg Dietary Survey of 1984/85. Ann Nutr Metab 1991:35: 284-291. 
66. Barker ME, McClean SI, McKenna PG, Reid NG, Sirain JJ, Thompson KA, Williamson AP. Wright ME. Diet, lifestyle and Health in Northern Ireland. Coleraine, University of Ulster, 1988.

67. Haraldsdóttir J, Holm L, Højmark Jensen J, Møller A. Danskernes Kostvaner 1985 1. Hovedresultater. Søborg: Miljøministeriet Levnedsmiddelstryrelsen, Publikation nr. $136,1986$.

68. Netherlands Nutrition Council: Guidelines for a Healthy Diet. The Hague: Voedingsraad, 1986.

69. Jensen HH, Nusser SM, Riddick H, Sands L. A critique of two methods for assessing the nutrient adequacy of diets. J Nutr Educ 1992;24: 123-129.

70. Löwik, Van den Berg H, Westenbrink S, Schrijver J, Mculme'sster JF, Kok FJ. Ockhuizen T. Risk groups among elderly people in the Netherlands: A review. (Dutch Nutrition Surveillance System). Age \& Nutrition 1992;3: 72-77.

71. Pao EM, Cypel YS. Estimation of dietary intake. In: Brown ML (ed). Present knowledge of nutrition. Washington DC: Nutr Found 1990;399-406.

72. Beaton GH. Uses and limits of the use of the recommended dictary allowances for evaluating dietary intake data. Am J Clin Nutr 1985;41: 155-164.

73. Brug J, Löwik MRH, Kistemaker C, Wedel M. Evaluatie van de vitamine B-6 voorziening van de Nederlandse bevolking. Voeding 1991:52: 4-9.

74. National Research Council. Nutrient Adequacy. Assessment using food consumption surveys. Washington DC: National academic Press, 1986.

74. Panel on Dietary Reference Values of the Committee on Medical Aspects of Food Policy. Dietary reference values for energy and nutrients for the United Kingdom. Report on Health and Social Subjects no 41, London: HSMO, 1991.

75. Feenstra MH. Genoeg van Vet. The Hague: Institute for consumer research. Swoka onderzoeksrapport nr. 100, 1990

76. Riedstra M, Hardeman W, Pruyn JFA, Aarnink EJM, Van der Feen de Lille JCJF, Jonkers R. De effecten van de tweede landelijke Let op Vet campagne, gehouden in 1992. Zeist: TNO-report nr V 92.453, 1992.

77. Surgeon General. Report on Nutrition and Health. U.S. Department of Health and Human Services. Washington DC: Public Health Service. DHHS (PHS) Publication No. $88-502010,1988$.

78. National Research Council. Diet and Health: Implications for Reducing Chronic Disease Risk. Washington DC: National academic Press, 1989.

79. Food and Nutrition Board. Recommended Dietary Allowances. 10th ed. National Washington DC: Academic Press of Sciences, 1989.

80. Randall E. Nichaman MZ, Contant CF. Diet diversity and nutrient intake. J Am Diet Assoc 1985;85: 830-836.

81. Smiciklas-Wright, Krebs-Smith SM, Krebs-Smith J. Variety in foods. In: What is America eating. Washington DC: National Research Council. 1986: 126-140.

82. Murphy SO. Rose D. Hudes M, Viteri FE. Demographic and economic factors associated with dietary quality for adults in the 1987-88 Nationwide Food Consumption Survey. J Am Diet Assoc 1992:92: 1352-1357.

83. Krebs-Smith SM, Smiciklas-Wright H, Guthrie HA, Krebs-Smith J. The effects if variety in food choices on dietary quality. J Am Diet Assoc 1987:87: 897-903.

84. Research policies for Health for all. Copenhagen: World Health Organization, Regional Office for Europe. 1989.

85. Fehily AM. Phillips KM, Yarnell JWG. Diet, smoking, social class and body mass index in the Caerphilly Heart Disease Study. Am J Clin Nutr 1984:40: 827-833.

80. Aro S, Räsänen L. Telama R. Social class and changes in health-related habits in Finland in 1973-1983. Scand J Soc Med 1986:14: 39-47.

87. Braddon FEM. Wadsworth MEJ, Davies JMC. Crips HA. Social and regional differences in food and alcohol consumption and their measurements in a national birth cohort. J Epidemiol Comm Health 1988;42: 341-349 
88. Brants HAM, Aarnink EJM, Hulshof KFAM, Kistemaker C, Löwik MRH

Vetconsumptie in Nederland. Deel 1: Doelgroepsegmentatie.

Voedselconsumptiepeiling 1987-1988. Zeist: TNO-report nr V 89.436, 1989.

89. Westenbrink S, Hulshof KFAM, Aarnink E. Kistemaker C, Löwik MRH. De inneming van enkele microvoedingsstoffen door de Nederlandse bevolking.

Voedselconsumptiepeiling 1987-1988. Zeist: TNO-report nr V 89.213, 1989.

90. Berkel-van Schaik AB, Tax B (rep). Naar een standaardoperationalisatic van sociaaleconomische status voor epidemiologisch en sociaal-medisch onderzoek. SociaalEconomische gezondheidsverschillen deel 6. The Hague: DOP 1990.

91. Fischler C. Man the omnivore and the social construction of food. In: Van der Heij DG (ed). Food and Nutrition Policy 1992. Proceedings of the 2nd European Conference on Food and Nutrition Policy (The Hague, 1992). Wageningen, Netherlands: Pudoc, 1993: 55-59.

92. Koltke TE, Gatewood LC, Wu SC, Park HA. Preventing heart disease: Is treating the right risk sufficient? J Clin Epidemiol 1988:41: 1083-1093.

93. Breslow L, Enstrom JE. Persistence of health habits and their relationship to mortality. Prev Med 1980;9: 469-483.

94. Wingard DL, Berman LF, Brand RJ. A multivariate analysis of health-related practices. Am J Epidemiol 1982;116: 765-775.

95. Belloc NB, Breslow L. Relationship of health status and health-related practices. Am J Epidemiol 1982;116: 765-775.

96. The Health of the Nation. A consultative document for health in England. London: HSMO, 1991.

97. Cronin FJ, Krcbs-Smith SM, Wyse BW, Light L. Characterizing food usage by demographic variables. J Am Diet Assoc 1982;81: 661-673.

98. Schwerin HS, Stanton JL, Riley AM, Schaeffer AE, Leveille GA, Elliot JG, Warwick $\mathrm{KM}$. Brett BE. Food eating patterns and health: a reexamination of the Ten-State and Hanes I surveys. Am J Clin Nutr 1981:34: 568-580.

99. Schwerin HS, Stanton JL, Smith JL, Riley AM. Brett BE. Food eating habits, and health: a further examination of the relationship between food eating patterns and nutritional health. Am J Clin Nutr 1982:35: 1319-1325.

100. Akin JS, Guilkcy DK. Popkin BM, Fanelli MT. Cluster analysis if food consumption patterns of older Americans. J Am Diet Assoc 1986;86: 616-624.

101. Nicklas TA, Webber LS, Thompson B, Berenson GS. A multivariate model for assessing eating patterns and their relationship to cardiovascular risk factors. Am J Clin Nutr 1989:49: 1320-1327.

102. Randall E, Marshall J, Graham S, Brasure J. Patterns in food use and their associations with nutrient intakes. Am J Clin Nutr 1990;52: 739-745.

103. Baecke JAH, Burema J, Frijters JER. Hautvast JGAJ, Wiel-Wetzels WAM van der. Obesity in young Dutch adults. II Daily lifestyle and body mass index. Int J Obesity 1983:7: 13-24.

104. Gofton L. Sociology and food consumption. Br Food J 1989:91: 25-31.

105. Axelson ML. A meta-analysis of food-and nutrition related research. J Nutr Educ 1985:17: 51-54.

106. Gillespie A. Achterberg CL. Comparison of family interaction patterns related to food and nutrition. J Am Diet Assoc 1989:89: 509-512.

107. Hollis JF. Carmody TP, Connor SL, Fey SG. Malarazzo JD. The Nutrition Attitude Survey: associations with dietary habits, psychological and physical well-being, and coronary risk factors. Health Psychology 1986;5: 359-374.

108. Waslien CJ. Factors influencing food selection in the American diet. Adv Food Res 1988;32: 239-269.

109. Witte DJ. Skinner JD, Garruth BR. Relationship of self-concept to nutrient intake and eating patterns in young women. J Am Diet Assoc 1991;91: 1068-1073. 



\section{Summary}

Growing awareness of the potential relationships between diet and health is accompanied by an increasing demand for information concerning eating patterns and the interdependence of diet with other life-style variables. The aim of the studies reported in this thesis was to investigate and evaluate the dietary patterns of the Dutch population, to identify risk groups, and to study the impact of severall life-style and sociodemographic factors and their interdependence on intake patterns. These issues were addressed using the data of the first Dutch National Food Consumption Survey (DNFCS).

According to the recommendations of the Netherlands Nutrition Council, the Dutch Nutrition Surveillance System should provide general information on food availability and consumption across the population, and detailed information on the nutritional status and health of specific vulnerable groups. In 1987-1988, the first DNFCS was carried out within the framework of this system (Chapter 3 ). The data refer to 2203 households selected from a panel by a probability sample among noninstitutionalized households; 5898 persons, aged 1-85, participated (response rate $81 \%$ ). Food consumption data were obtained using a 2-day record method. In addition to the food consumption data, information was collected on the respondent's body weight, height (both self-reported figures), use of nutritional supplements, special dietary practices, smoking habits, meal patterns and hours of sleep during the two consecutive days of the survey by means of a structured questionnaire included in the personal diary. Information about education, occupation, demographic and socio-economic variables were obtained from the marketing research institute AGB-Attwood which carried out the field work. Since it is not very likely that the presented data have been affected substantially and/or systematically by study design, data collection or data handling, the data presented can be considered to be representative of the Dutch population aged 1-85, living in households with a housekeeper younger than 75 years. Excluded were households whose members could not speak or read Dutch. The data constitute a representative, reliable and valid source of information useful for studies on the eating pattern of the Dutch population and for risk assessment.

Like the Netherlands, several industrialized countries have carried out nutritional surveys based on a national sample (Chapter 2). Across countries there are differences in coverage of the population, dietary methods, nutrition-and healthrelated indicators etc. As to the general ideas of the dietary parts of systems, the: Dutch system is in line with those in other industrialized countries, for instance concerning the choice to collect data at the individual level. Until now studying trends by using this type of data is hampered by the irregularity of data collection at the national level and/or by changes in survey methods over time. The Netherlands is one of the few countries in which national surveys at the individual level are being repeated (1992). 
The data of the first DNFCS showed that the average diet was not a prudent one as to the risk of cardiovascular disease and some types of cancer. Compared with the Dutch Guidelines for a healthy diet, the average intake of fat (especially of saturated fatty acids) was too high, whereas the intake of total carbohydrates (particularly of polysaccharides) and dietary fibre was too low (Chapter 4). Among respondents of the DNFCS about $20 \%$ of the women and $23 \%$ of the men aged 4 years and over met the goal for fat intake, $20 \%$ of the men and $27 \%$ of the women for dietary fibre and about 60 and $70 \%$ for mono- and disaccharides and cholesterol, respectively. Only $3 \%$ of the subjects had diets with $\leq 10 \%$ of energy derived from saturated fatty acids. In younger age groups more subjects met the guidelines for fat and cholesterol, whereas for mono- and disaccharides and dietary fibre higher proportions were found for adolescents and adults. Lower percentages were observed when dietary goals were combined. Less than $1 \%$ had diets in accord with all criteria studied.

A two-day record does not measure habitual intake of an individual, whereas effects on health in Western countries may occur in the long run. Adjustment of distributions for within-person variance may provide more accurate prevalence estimates than unadjusted ones. It was found that among elderly people adjustment did not improve the prevalence estimates when compared with distributions reflecting habitual intake. Therefore, it was concluded that the issue of adjustment for within-person variance should be studied in more detail.

In comparing energy-related nutrients with guidelines, the intake of alcohol may be a confounder in risk assessment, since alcohol and for instance fat intake were inversely related. Therefore, guidelines should state explicitly whether energy-related ricommendations include energy derived from alcohol. Besides a distortion of the estimate of intake levels, comparisons among subgroups may be hampered. For instance, a higher socio-economic status (SES) was associated with a lower fat intake but differences (expressed as \% of energy intake) were rather small and even absent among women when the contribution of alcohol to energy intake was taken into account (Chapter 5). In comparison to adults with a high SES the low social class had a higher proportion of smokers ( $48 \mathrm{vs.} 32 \%$ ), a higher prevalence of obesity ( 39 vs. $28 \%$ ), and a higher percentage of heavy coffee drinkers (more than six cups per day, 23 vs. $17 \%$ ), whereas in the highest social class a higher proportion of subjects drank more than three alcoholic drinks per record-day (19 vs. $15 \%)$. In the high social class subjects more often followed a dietary rule such as a vegetarian diet (5 vs. $2 \%$ ), and more subjects used nutritional supplements (18 vs. $11 \%$ ). Both for men and women those belonging to the low social class had a higher consumption of potatoes and meat, but the consumption of fruits, cereals and cheese was lower. Men, but not women, with a low SES consumed more fats and sugar (products) than those in the higher classes. Within food groups, the consumption of products with a lower fat content was highest in the higher SES groups. Overall dietary intake tended to be closer to dietary recommendations in higher SES groups, but none of the groups had on the average a really prudent diet. 
Differences in mean food consumption among SES groups were relatively small. Classifying people according to their consumption pattern by simultaneously considering various relevant aspects of the diet might provide larger differences among population groups. For this a cluster analysis was performed (Chapter 6). Respondents of the DNFCS aged 19-85 were classified into groups based on simularities in nutrient intake. The criteria used for classification were fat (\% of energy intake), $\mathrm{P} / \mathrm{S}$ ratio, dietary fibre ( $\mathrm{g} / \mathrm{MJ}$ ), cholesterol (mg/MJ), mono- and disaccharides (\% of energy intake) and alcohol ( $g$ /day). To restrict the influence of alcohol on the other variables used in the clustering, the calculation of energy was exclusive of the energy derived from alcohol. Eight clusters were found. In four clusters the dietary quality deviated substantially from the guidelines for a healthy diet. The clusters identified were characterized by sociodemographic and life-style factors as well as by the consumption of food groups. Smoking, body mass index, dietary regimen on own initiative, hours of sleep, gender, age, SES, day of the week and the consumption of several food groups were found to discriminate among the clusters, indicating that undesirable life-style factors were interrelated in some clusters. Although the clusters differed substantially as to dietary characteristics, no consistent associations with non dietary life-style factors were observed.

Population groups may differ in dietary intake as a result of differences in degrec of variety, and variety is assumed to be a prerequisite for an adequate diet. Therefore, the relationship of variety in food consumption and dietary adequacy (based on nutrient density) was studied (Chapter 7). The concept of variety included variety among and within (major) food groups and also attention was paid to the nutrient profile of unique food items. Among men and women aged 22-49, all reported food items were classified into 43 food groups based on food origin and pattern of use. Subjects were assigned to 5 variety categories, on the basis of their position within the distribution for food variety (for men and women separately), with each category representing about $20 \%$ of the population. The results showed that a higher level of food variety was associated generally with a higher nutrient intake and a higher energy intake. A consistent pattern for the relation between food variety parameters and nutrient density, however, was not observed. The proportion of subjects using one or more products from all major food groups (i. e. vegetables, fruits, potatoes, cereals, dairy and meat) differed markedly among the categories, with the lowest proportion among those having low food variety. Differences in the use of fruits, followed by that of vegetables, were the main determinants of these findings. The association between variety and dietary intake is characterized mainly by differences in quantity. These observations indicate that eating a variety of food does not automatically lead to a more adequate diet. Explanations may be that the dietary pattern is too homogeneous to show any differences, or that a variety treshold is surpassed above which no residual differences can be found.

In summary, the average Dutch diet in $1987 / 88$ was not in agreement with the guidelines for a healthy diet. A priori segmentation of subgroups based on socioeconomic and demographic variables revealed relatively small differences in dietary 
pattern, whereby nutritional health risks were dispersed throughout Dutch population groups. Post hoc segmentation by means of cluster analysis led to the identification of groups with much more differences in dietary intake variables, and some of the clusters had deviant prevalence values of (un)favourable life-style factors. For a better characterization of the clusters, indices of life-style and sociodemographic characteristics other than the traditional ones might be a valuable extension. 


\section{Samenvatting}

Het verbeterde inzicht in de relatie tussen voeding en gezondheid gaat gepaard met een toenemende vraag naar informatie over consumptiepatronen en de onderlinge samenhang tussen voeding en andere levensstijlkenmerken. Het onderzoek dat in dit proefschrift wordt beschreven was erop gericht de voeding van de Nederlandse bevolking te beoordelen en evetuele risicogroepen te identificeren. Bovendien werd de invloed van verschillende levensstijlkenmerken en sociodemografische factoren alleen en in onderlinge samenhang met de voedselconsumptie nader bestudeerd. Hiervoor is gebruik gemaakt van het databestand van de eerste Nederlandse voedselconsumptiepeiling (VCP).

Volgens de aanbevelingen van de Voedingsraad zou het Nederlandse voedingspeilingssysteem moeten bestaan uit twee onderdelen. Het systeem moet enerzijds gegevens verschaffen over de beschikbare voedingsmiddelen en over de gemiddelde voedselconsumptie van verschillende categorieën van de bevolking op basis van individueel voedselconsumptieonderzoek bij een landelijk representatieve steekproef. Anderzijds moet informatie worden verzameld bij specifieke bevolkingsgroepen over de voedingstoestand (eventueel in combinatie met hun voedselconsumptie). In het kader van de eerste doelstelling van het voedingspeilingssysteem werd in 1987-1988 de eerste VCP uitgevoerd (hoofdstuk 3). Voor de steekproeftrekking is gebruik gemaakt van een bestaand onderzoekspanel dat een representatieve afspiegeling vormt van de Nederlandse huishoudens. Aan het onderzoek is deelgenomen door 5898 personen (2203 huishoudens) in de leeftijd van 1-85 jaar (respons $81 \%$ ). De gegevens over de voeding zijn verkregen met behulp van een tweedaagse opschrijfmethode. Naast informatie over de voeding is in de dagboekjes ook gevraagd naar het lichaamsgewicht en de lengte van de respondent, het gebruik van voedingssupplementen, speciale voedingsgewoonten, rookgewoonten, maaltijdpatroon en het aantal uren slaap per etmaal gedurende de twee aaneengesloten onderzoekdagen. Gegevens over opleiding, beroep, demografische en socio-economische variabelen waren beschikbaar via het marktonderzoeksbureau dat het veldwerk uitvoerde, te weten AGB Attwood. Er zijn geen aanwijzingen dat de gepresenteerde gegevens wezenlijk en/of systematisch zijn beïnvloed door de onderzoeksopzet, dataverzameling of dataverwerking. De gegevens worden geacht representatief te zijn voor de Nederlandse bevolking van 1-85 jaar, wonend in huishoudens met een huisvrouw of -man jonger dan 75 jaar. Personen die in instellingen verbleven en personen die de Nederlandse taal niet machtig waren (in woord en/of geschrift) zijn niet in de steekproef opgenomen. De verzamelde gegevens vormen een representatieve, betrouwbare en valide bron van informatie die gebruikt kan worden voor de evaluatie van de voedselconsumptie van de Nederlandse bevolking en voor het identificeren van risicogroepen.

Verschillende geïndustrialiseerde landen hebben op landelijk niveau voedingsonderzoek uitgevoerd (hoofdstuk 2). Er bestaan weliswaar enige verschillen in de 
selectie en samenstelling van de onderzochte doelgroepen, in methoden van voedselconsumptieonderzoek en in indicatoren met betrekking tot voeding en gezondheid. Wat betreft de grondslagen komt echter de Nederlandse voedselconsumptiepeiling in grote lijnen overeen met hetgeen bij de systemen van andere geïndustrialiseerde landen wordt toegepast, bijvoorbeeld de keuze met betrekking tot het nagaan van de voedselconsumptie op individueel niveau. Tot op heden wordt het bestuderen van trends belemmerd door de onregelmatigheid waarmee gegevens op landelijk niveau worden verzameld en/of door veranderingen in onderzoeksmethoden. Nederland is één van de weinige landen waar een landelijk onderzoek met gegevensverzameling bij individuen op uniforme wijze is herhaald (1992).

De VCP-gegevens uit 1987-1988 toonden aan dat de gemiddelde Nederlandse voeding geen prudente voeding is voor wat betreft het risico op hart- en vaatziekten en sommige vormen van kanker. Vergeleken met de Richtlijnen Goede Voeding (RGV) was de gemiddelde inneming van vet (met name van verzadigde vetzuren) te hoog en de inneming van koolhydraten (vooral van polysacchariden) en voedingsvezel te laag (hoofdstuk 4). Van de populatie van 4 jaar en ouder realiseerde $20 \%$ van de vrouwen en $23 \%$ van de mannen de richtlijn voor vet en $20 \%$ van de mannen en $27 \%$ van de vrouwen die voor vezel. De richtlijnen voor mono- en disacchariden en cholesterol werden door $60-70 \%$ van de populatie bereikt. Bij vet en cholesterol nam het percentage personen dat de richtlijn haalde af met de leeftijd, bij mono- en disacchariden en voedingsvezel werd het omgekeerde geconstateerd. Minder dan 1\% gebruikte een voeding die voldeed aan alle onderzochte criteria van de RGV.

De invloed van voeding op de gezondheid in Westerse landen heeft in het algemeen een lange termijn karakter, terwijl een tweedaagse opschrijfmethode niet de gebruikelijke individuele voeding weerspiegelt. Het corrigeren van een verdeling van de inneming voor de binnen-persoonsvariatie leidt in theorie tot een nauwkeuriger schatting van prevalentiecijfers. Vergeleken met gegevens over de gebruikelijke voeding leidden gecorrigeerde schattingen bij ouderen echter niet tot een verbetering van prevalentiecijfers. Dit onderwerp dient nader bestudeerd te worden.

$\mathrm{Bij}$ het vergelijken van de inneming van voedingsstoffen met de RGV kan de inneming van alcohol voor voedingsstoffen die worden uitgedrukt op basis van energie (in energieprocenten (en\%) of per eenheid energie (per MJ)) risicoschattingen verstoren; de inneming van alcohol en bijvoorbeeld vet bleken invers gerelateerd. Het is daarom van wezenlijk belang dat richtlijnen uitdrukkelijk vermelden of voor een beoordeling van een aan energie gerelateerde inneming de energie uit alcohol wel of niet moet worden meegeteld. De consumptie van alcohol kan ook vergelijkingen tussen groepen bemoeilijken. Een hogere sociaaleconomische status (SES) was bijvoorbeeld geassocieerd met een lagere vetinneming (uitgedrukt in en\%), maar de verschillen werden geringer en waren bij vrouwen zelfs afwezig indien de inneming werd berekend exclusief de energiebijdrage van alcohol (hoofdstuk 5). Vergeleken met de hoge SES werd in de lage SES-groep het hoogste percentage rokers ( 48 t.o.v. 32), het hoogste percentage personen met obesitas (39 t.o.v. 28) en met een hoge koffieconsumptie (meer dan 6 koppen per dag, 23 t.o.v. 
17) aangetroffen. In de groep met een hoge SES werd door $19 \%$ meer dan drie glazen alcoholische dranken per onderzoeksdag gedronken; in de groep met een lage SES was dit $15 \%$. In de hoge SES-groep volgden meer personen een speciale leefregel in relatie tot de voeding, bijvoorbeeld vegetariërs ( 5 t.o.v. $2 \%$ ), en meer personen gebruikten voedingssupplementen (18 t.o.v. 11\%). Mannen en vrouwen in de groep met een lage SES aten meer aardappelen en vlees en minder fruit, graanprodukten en kaas. Bij mannen met een lage SES was ook de consumptie van zichtbare vetten en suikerbevattende produkten hoger dan in de groep met een hoge SES. Binnen produktgroepen bleken personen met een hogere SES vaker varianten met een lager vetgehalte te kiezen. De gemiddelde voeding van personen met een hoge SES benaderde de aanbevolen voeding wat dichter dan die van personen met een lage SES, maar geen van de onderzochte groepen gebruikte een prudente voeding.

Omdat de verschillen in de gemiddelde consumptie betrekkelijk gering waren en het indelen van personen op basis van consumptiepatronen mogelijk tot grotere verschillen tussen bevolkingsgroepen zou kunnen leiden, werd een clusteranalyse uitgevoerd (hoofdstuk 6). Respondenten van de VCP, in leeftijd variërend van 19 tot 85 jaar, werden in groepen ingedeeld op grond van overeenkomsten in inneming van relevant geachte voedingsstoffen. Als criteria voor de clustering werden gebruikt: vet (en\%), P/S-ratio, voedingsvezel ( $\mathrm{g} / \mathrm{MJ}$ ), cholesterol (mg/MJ), mono- en disacchariden (en\%) en alcohol ( $\mathrm{g} / \mathrm{dag}$ ). Om de invloed van alcohol op de inneming van energie uit te sluiten zijn de genoemde clustercriteria berekend exclusief de energie uit alcohol. Er werden 8 clusters onderscheiden. In 4 clusters was de kwaliteit van de voeding wezenlijk afwijkend van een voeding volgens de RGV. De geidentificeerde clusters werden beschreven door middel van sociaal-demografische en levensstijlkenmerken en door de consumptie van groepen voedingsmiddelen. Tussen de clusters werden verschillen aangetroffen wat betreft Quetelet-index, roken, dieet op eigen initiatief, aantal uren slaap, leeftijd, geslacht, SES, type onderzoeksdag en de consumptie van een aantal groepen voedingsmiddelen. Dit duidt op een samenhang tussen een aantal ongewenste levensstijlkenmerken in sommige clusters. Hoewel de samenstelling en kenmerken van de voeding in de clusters duidelijk verschilden, vertoonde de relatie met de overige levensstijlkenmerken geen consistent beeld.

Variatie wordt algemeen beschouwd als een voorwaarde voor een adequate voeding. Als gevolg van verschillen in de mate van variatie kan de inneming van voedingsstoffen tussen bevolkingsgroepen verschillen. Daarom werd de relatie tussen variatie in consumptie van voedingsmiddelen en een adequate voeding (gebaseerd op voedingsstoffendichtheid) nader bestudeerd (hoofdstuk 7). Het concept van variatie omvatte de variatie binnen en tussen (belangrijke) groepen voedingsmiddelen, waarbij ook rekening werd gehouden met het gehalte aan voedingsstoffen in de afzonderlijke produkten. Alle afzonderlijke voedingsmiddelen, gerapporteerd door 22-49-jarigen, werden ingedeeld in 43 produktgroepen, naar herkomst van het produkt en de wijze van gebruik. Op basis van het aantal gebruikte 
produktgroepen werden de personen toegewezen aan éên van de 5 variatiecategorieën (afzonderlijk voor mannen en viouwen), waarbij iedere categorie ongeveer $20 \%$ van de populatie vertegenwoordigde. Een hoge mate van variatie was in het algemeen geassocieerd met een hogere inneming van zowel voedingsstoffen als energie. Het verband tussen variatie in voedingsmiddelengebruik en voedingsstoffendichtheid vertoonde geen eenduidig beeld. Het percentage personen dat één of meer produkten van alle belangrijke produktgroepen (d.w.z. groente, fruit, aardappelen, granen, melk en vlees) gebruikte verschilde aanzienlijk naar mate van variatie en was het laagst in de categorie met de geringste variatie. Het verschil in het gebruik van fruit, gevolgd door het verschil in groentegebruik, bleek de belangrijkste determinant voor deze bevinding. De samenhang tussen variatie en inneming van voedingsstoffen kenmerkte zich door een verschil in hoeveelheid. De bevindingen duiden erop dat een gevarieerd gebruik van voedingsmiddelen niet vanzelfsprekend leidt tot een adequate voeding. Een mogelijke verklaring hiervoor is dat het voedingspatroon te homogeen is om verschillen aan te tonen, of dat er een drempel voor variatie is overschreden waarboven geen verschillen meer waarneembaar zijn.

Samenvattend kan worden gesteld dat de gemiddelde Nederlandse voeding in $1987 / 88$ niet overeenstemde met de RGV. A priori-segmentatie op basis van sociaaleconomische en demografische kenmerken leidde tot betrekkelijk geringe verschillen in voedingspatronen. Aan voeding gerelateerde gezondheidrisico's komen verspreid voor bij Nederlandse bevolkingsgroepen. Post hoc-segmentatie op basis van clusteranalyse leidde tot de identificatie van groepen met duidelijke verschillen in de inneming van voedingsstoffen. In sommige clusters werd eveneens een, ten opzichte van het gemiddelde, afwijkend aantal (on)gunstige levensstijlkenmerken aangetroffen. Voor het realiseren van een betere typering van de clusters zouden andere dan de traditionele levensstijl-indicatoren en sociaal-demografische kenmerken mogelijk een waardevolle uitbreiding zijn. 


\section{Curriculum Vitae}

Karin F.A.M. Hulshof werd op 30 juni 1946 te Lichtenvoorde geboren. In 1963 behaalde zij het diploma HBS-A aan het 'Marianum' te Groenlo. Aansluitend volgde zij de opleiding diëtetiek te Nijmegen en behaalde in 1967 haar diploma. Van 1967 tot 1976 was zij als diëtist klinisch en poliklinisch werkzaam in het St Jozefziekenhuis te Doetinchem. Van 1976 tot 1989 was zij als hoofddiëtist werkzaam bij de afdeling Voeding (hoofd dr. Th. Ockhuizen) van het Instituut Toxicologie en Voeding TNO (directeur prof. dr. ir. R.J.J. Hermus). Zij was betrokken bij experimenteel-fysiologisch en epidemiologisch voedingsonderzoek. Haar onderzoekactiviteiten richtten zich met name op het onderzoek naar de voedselconsumptie en voedingstoestand bij diverse bevolkingsgroepen in Nederland en op methodologische aspecten van voedselconsumptieonderzoek. Van 1989 tot 1993 werkte zij bij de sectie Beleidsstudies en Biostatistiek (hoofd dr. ir. M.R.H. Löwik) aan het in dit proefschrift beschreven onderzoek. Sinds 1993 werkt zij als onderzoeker binnen deze sectie en coördineert en stimuleert zij als secretaris van de Beheerscommissie Voedselconsumptiepeiling het gebruik van gegevens uit de voedselconsumptiepeilingen. Verder is zij intensief betrokken bij onderzoeksactiviteiten die onder meer worden verricht in het kader van het voedingspeilingssysteem. 
